\title{
The Retreats of Reconstruction: Race, Leisure, and the Politics of Segregation at the New Jersey Shore, 1865--1920
}

\author{
David E. Goldberg \\ West Virginia University
}

Follow this and additional works at: https://researchrepository.wvu.edu/etd

\section{Recommended Citation}

Goldberg, David E., "The Retreats of Reconstruction: Race, Leisure, and the Politics of Segregation at the New Jersey Shore, 1865--1920" (2013). Graduate Theses, Dissertations, and Problem Reports. 442.

https://researchrepository.wvu.edu/etd/442

This Dissertation is protected by copyright and/or related rights. It has been brought to you by the The Research Repository @ WVU with permission from the rights-holder(s). You are free to use this Dissertation in any way that is permitted by the copyright and related rights legislation that applies to your use. For other uses you must obtain permission from the rights-holder(s) directly, unless additional rights are indicated by a Creative Commons license in the record and/ or on the work itself. This Dissertation has been accepted for inclusion in WVU Graduate Theses, Dissertations, and Problem Reports collection by an authorized administrator of The Research Repository @ WVU.

For more information, please contact researchrepository@mail.wvu.edu. 


\title{
The Retreats of Reconstruction: Race, Leisure, and the Politics of Segregation
} at the New Jersey Shore, 1865-1920

\author{
David E. Goldberg
}

\author{
Dissertation submitted to \\ the Eberly College of Arts \& Sciences \\ at West Virginia University \\ in partial fulfillment of the requirements \\ for the degree of
}
Doctor of Philosophy
in History

\author{
Aaron Sheehan-Dean, Ph.D., Chair \\ Dr. Brian Luskey, Ph.D. \\ Dr. Ken Fones-Wolf, Ph.D. \\ Krystal Frazier, Ph.D. \\ Peter Carmichael, Ph.D. \\ Department of History

$$
\text { Morgantown, WV }
$$

2013

Keywords: Segregation, Civil Rights, Leisure

Copyright 2013 David E. Goldberg 


\section{ABSTRACT \\ The Retreats of Reconstruction: Race, Leisure, and the Politics of Segregation at the New Jersey Shore, 1865-1920}

\section{David E. Goldberg}

This dissertation examines the political meanings of consumption and racial segregation in the public and commercial leisure spaces of the New Jersey shore during the Reconstruction era. Moving beyond issues of identity, racial violence, and labor disputes, I show how Jim Crow unfolded and operated in the post-Civil War North by emphasizing the importance of political economy and ideas about public health and welfare. Beginning in the 1880 s, ideas about the rights and health of consumers became more important in helping shape the meanings of freedom than did the triumph of free labor ideology. The rise of mass consumption as a guiding principle of economic growth, and the debates about political economy that it spurred-intertwined with the ideologies that led to Jim Crow segregation at the Jersey shore.

Throughout the late-nineteenth century, both whites and blacks used the ideologies of the marketplace to shape and resist segregation at northern beach resorts. White segregationists argued that Jim Crow laws were legal and necessary since they preserved the sanctity of property, privacy, and social propriety. In contrast, African Americans employed a variety of consumer-focused tactics to desegregate northern beach towns, shape their own independent leisure districts, and discredit the environmental inequalities of service economies. By making consumer rights and public health central to the struggle against segregation, northern black activists successfully made sites of entertainment and consumption critical battlegrounds in a national campaign for civil rights, market fairness, and environmental justice during the early Jim Crow era. 


\section{ACKNOWLEDGEMENTS}

The men and women who fought for freedom on the beaches of the New Jersey shore reminded me that we owe most of our personal triumphs to those who walk beside us. Over the past seven years, this project has benefited from an untold number of professors, advisors, archivists, students, classmates, roommates, friends, family members, conference panelists, and anonymous reviewers who helped shape and influence this dissertation. Time and again, I was struck by their devotion, knowledge, and patience as I shared early drafts, occasional frustrations, and "humbly" crossed the finish line.

This project started as a seminar paper in Dr. Judy Giesberg's Reconstruction course at Villanova University in 2006. As the original champion of this topic, I owe immense gratitude to her for her thoughtful reading of early drafts and continued support throughout the years. Dr. Peter Carmichael next directed the project through its initial stages as a Dissertation proposal at West Virginia University. Pete's “tenacious” and satirical editing helped fine-tune its argument(s) and clarify its prose. He continues to shape and guide my career in immeasurable ways, and I thank him for his continued support, friendship, and impressive network of connections within the profession. After departing WVU in 2010, Pete graciously passed the torch to Aaron Sheehan-Dean, whose seamless guidance of this project's final stages is a reflection of his immense editorial talent. Ken Fones-Wolf, Brian Luskey, Krystal Frazier, and John Ernest each brought a diverse set of skills and individual expertise to the project. I hope they will find that the final draft is a reflection of their consistent interest and substantive feedback on its earlier drafts. 
In between writing and researching, I had an opportunity to teach hundreds of students at both Villanova University and West Virginia University. These talented and inspiring men and women provided welcomed reprieves from the anonymity of the scholar's life. It was my pleasure to be their professor and I wish them all the best in their own professional careers. Nate Hall and Timmy Poydenis-you're still the best! These research and writing breaks were also spent in the company of many friends and family members, especially those from my days at Elizabethtown College. To Matt Woehnker, Eric Wetzel, Mike Grecco, Brian Bonner, and Steve Luongo, along with the countless other Blue Jays - thank you for the glory days!

Since then, I've had the privilege of meeting many important colleagues and graduate school friends. As an undergraduate student, Dr. David Brown taught me how to be a scholar and his career continues to be a model for aspiring historians. At WVU, I was lucky to serve as a teaching assistant for Tyler Boulware, who has proven time and again to be an invaluable teaching mentor and professional sounding board. I also wish to thank and recognize Brandon Williams, Joe Rizzo, Cara Snider, Josh Esposito, Karina Garcia, Lauren Thompson, Joel Christenson, David Williams, Stuart Collins, and Dan Rutledge. Each of you greatly aided in the personal and scholarly enjoyment of my time at Villanova and WVU. Thank you for your guidance, patience, and most importantly, the much-needed comic relief.

Of course, I especially wish to thank my parents. My mom was my first editor and continues to nourish my personal and professional life with her boundless love, unyielding support, and daily conversation. From the ball fields to the classroom, my 
father has consistently proven to be an impeccable model of what it means to be a man, father, and professional. I hope this dissertation resembles the values they both continue to exude. Thank you as well to my sister Gabrielle, my grandparents Barney and Elaine Goldberg, and my "every loving grandmother" Josie Christenson, who provided not only love and support, but free room and board!

Lastly, I wish to thank two people who provided the "spiritual" introduction to this project. In 2003, Matt Woehnker introduced me to the music and songbook of Bruce Springsteen. Since then, the Boss's lyrics and anthems have not only bonded our friendship, but also served as a constant source of rejuvenation and inspiration during this project's lengthy tenure. In them I discovered the magic of the Jerseys shore's mystical and enigmatic hold over American culture, and was inspired to narrate the stories and activism of those who also "had a notion" to fight for a free and socially responsible society. Thanks Bruce and Matt! 


\section{Table of Contents}

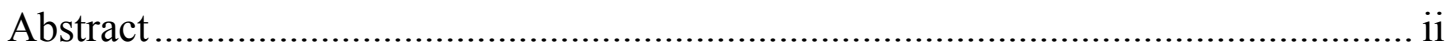

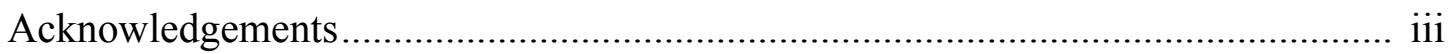

Introduction:

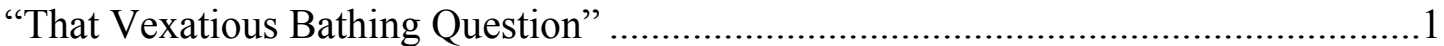

Chapter One:

The Struggle to Define Segregation, 1861-1893 …................................................. 21

Chapter Two:

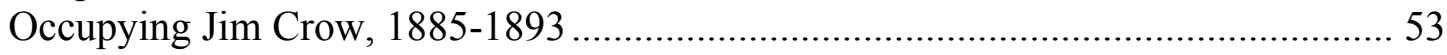

Chapter Three:

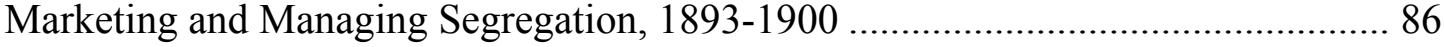

Chapter Four:

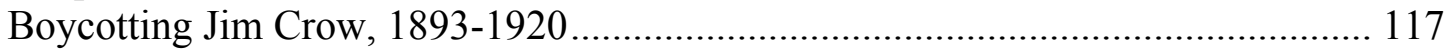

Chapter Five:

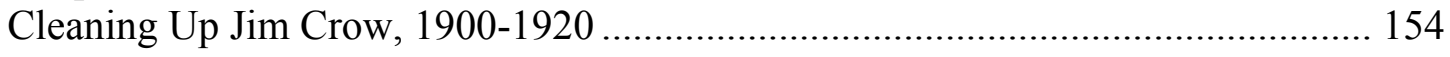

Conclusion:

"You'll Have to Use Your Imagination": Remembering Segregated Summers....... 187

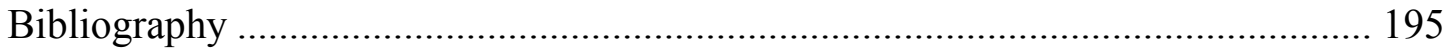




\section{Introduction: "That Vexatious Bathing Question"}

On July 23, 1893, an editorial in the Philadelphia Inquirer asked frustrated business owners and tourist promoters of Atlantic City "What are we going to do with our colored people?" Noting that "never before" had the resort community seemed "so overrun with the dark skinned race as this season," Atlantic City and other popular northern resort destinations struggled throughout the Reconstruction period to contain the recreational activities of black vacationers. ${ }^{1}$ As these struggles reveal, contests over segregation were not restricted to former plantation districts, northern legislatures, or public transportation systems. In the late-nineteenth century, the popularity of the New Jersey shore coincided with growing concerns over civil rights. On beaches, boardwalks, and amusement venues, African Americans' claims for integrated leisure were imbedded in political debates over the meaning of race, the memory of Reconstruction, and the rights and health of consumers.

For the northern white tourists who visited the beach resorts of the New Jersey coast, summer vacations were not just valuable moment away from work or idle time to spend with family and friends. ${ }^{2}$ In the aftermath of the Civil War, many working-class whites imagined the Jersey shore as a retreat from the sordid politics of the Gilded Age, the regimentation of industrial order, and the turmoil of black civil rights activism. To

\footnotetext{
${ }^{1}$ Philadelphia Inquirer, July 23, 1893, 10.

${ }^{2}$ For a short list of studies that detail the political uses of vacation destinations and tourist sites during the Gilded Age and Progressive era, see esp. Cindy Aron, Working at Play: A History of Vacations in the United States (New York, 1999); Jon Sterngrass, First Resorts: Pursuing Pleasure at Saratoga Springs, Newport, and Coney Island (Baltimore, 2001); John F. Kasson, Amusing the Millions: Coney Island at the Turn of the Century (New York, 1978); David Nasaw, Going Out: The Rise and Fall of Public Amusements (Cambridge, 1999); Catherine Cocks, Doing the Town: The Rise of Urban Tourism in the Unites States, 1815-1915 (Berkeley, 2001); John Sears, Sacred Spaces: American Tourist Attractions in the Nineteenth Century (New York, 1989); Marguerite S. Shaffer, See America First: Tourism and National Identity, 1880-1940 (Washington, D.C., 2001); Dona Brown, Inventing New England: Regional Tourism in the Nineteenth Century (Washington, D.C., 1997).
} 
these aspiring men and women, summer trips to the seashore offered unique political opportunities to create and shape an egalitarian public sphere devoid of the pretentious class divisions that presided over many antebellum era leisure spots. Olive Logan, writing for Harper's New Monthly Magazine in 1876 explained that the Jersey shore "has equal attraction for rich and poor." There is nothing exclusive," she proudly observed, "about any of the hotel bathing grounds." 3 Stephen Crane, who visited the popular summertime resort of Asbury Park in the 1880s and 1890s, agreed, remarking that it was the "greatest summer resort of America - the vacation abode of the mighty middle class." ${ }^{4}$ Yet, by the mid-1880s, white tourists increasingly encountered African Americans who refused to be props in the popular culture landscape of these vacation fantasylands. Staking out their own claim to a expanding leisure marketplace, black seasonal workers demanded a racially integrated public sphere and their challenges threatened to discredit the social standing, racial identity, and escapist dreams of whites.

Drawing on press accounts, promotional materials, and business records, this dissertation chronicles the early civil rights history of the Jersey shore. In particular, it asks what the history of Reconstruction-era debates in northern leisure settings can reveal about the politics of segregation and consumption after the Civil War. ${ }^{5}$ Despite a large

\footnotetext{
${ }^{3}$ Olive Logan, "Long Branch, 1876," Harper's New Monthly Magazine, vol. 53, no. 316 (September 1876).

${ }^{4}$ Stephen Crane, "Asbury Park As Seen By Stephen Crane," Kansas City Star, August 22, 1896. See also, Stephen Crane, "Joys of Seaside Life," New York Tribune, July 17, 1892.

${ }^{5}$ Although there have been other studies done on African American communities and activists at the Jersey Shore, this will be the first to fully document and conceptualize the totality of Civil Rights campaigns and segregation efforts from the end of the Civil War to 1920. Studies that document the early history of African American communities in Atlantic City include, Henry James Foster, "The Urban Experience of Blacks in Atlantic City, New Jersey: 1850-1915" (PhD diss., Rutgers, The State University of New Jersey, 1981); Richlyn F. Goddard, "Three Months to Hurry, Nine Months to Worry: Resort Life for African Americans in Atlantic City, 1854-1940" (PhD diss., Howard University, 2001); and Nelson Johnson, The Northside: African Americans and the Creation of Atlantic City (New York: Plexus Publishing, 2010). For works that mention the persistence of race relations at the Jersey Shore, as well as neighboring resorts in Philadelphia, see esp. Charles E. Funnell, By the Beautiful Sea: The Rise and High Times of that Great American Resort, Atlantic City (New Brunswick, 1975); Martin Paulsson, The Social Anxieties of
} 
volume of works that focus on the history of race and the cultural politics of Jim Crow during the nineteenth century, we still have an incomplete picture of how de facto segregation — as both a policy and an idea — functioned in northern society. ${ }^{6}$ How did competing visions of political economy, and in particular, consumer rights, influence the vernacular and statutory boundaries of segregation? What strategies and tactics did African Americans utilize to win access to leisure spaces and shape their own independent entertainment venues? What role did environmental inequalities and concerns over public health play in policing and contesting segregation in consumer leisure districts? The answers to these questions elude the preoccupation with identity, racial violence, and labor disputes that has recently framed segregation history.

In his 1955 study, The Strange Career of Jim Crow, C. Vann Woodward famously remarked that "one of the strangest things" about the appearance of segregation was that "it was born in the North and reached an advanced age before moving to the South in force." ${ }^{7}$ Since then, historians who have written about the making of Jim Crow

Progressive Reform: Atlantic City, $1854-1920$ (New York, 1994); Bryant Simon, Boardwalk of Dreams: Atlantic City and the Fate of Urban America (New York, 2004); Daniel Wolff, $4^{\text {th }}$ of July, Asbury Park: A History of the Promised Land (New York, 2005); and Brian E. Allnut, "The Negro Excursions:

Recreational Outings among Philadelphia African Americans, 1876-1926," Pennsylvania Magazine of History and Biography 129 (January, 2005): 73-104.

${ }^{6}$ For a small sample on the history of race in America, see Winthrop Jordan, White Over Black: American Attitudes Toward the Negro, 1550-1812, (Chapel Hill, 1968); Thomas F. Gossett, Race: The History of an Idea in America, (1963), reprinted (New York, 1997); George Fredrickson, The Black Image in the White Mind: The Debate on Afro-American Character and Destiny, 1817-1914, (1971, reprinted with a new introduction, (Hanover, 1987); Lee D. Baker, From Savage to Negro: Anthropology and the Construction of Race, 1896-1954, (Berkley, 1998); James Brewer Stewart, "The Emergence of Racial Modernity and the Rise of the White North, 1790-1840, Journal of the Early Republic 18 (Spring 1998): 181-217; and William L. Van Deburg, Hoodlums: Black Villains and Social Bandits in American Life, (Chicago: University of Chicago Press, 2004).

${ }^{7}$ C. Vann Woodward, The Strange Career of Jim Crow, (third revised edition, New York: Oxford University Press, 1973). Following Woodward's example, Leon Litwack surveyed the pervasiveness of racial discrimination in framing segregation in the antebellum North, concluding that "virtually every phase of existence" was closed off to black Americans. Leon Litwack, North Slavery: The Negro in he Free States: 1790-1860 (Chicago, 1961). Recent work by Blair Kelley, Judy Giesberg, and Kate Masur has begun to qualify these conclusions by documenting the persistent African-American resistance efforts to desegregate public accommodations during the Civil War era. Blair Kelley, Right to Ride: Streetcar 
in the North have generally noted the powerful political vocabulary of "social equality," miscegenation, and the "wages of whiteness" in limiting more progressive Civil Rights initiatives during the Reconstruction period. ${ }^{8}$ Whiteness scholars have touted debates over public memory, cultural discussions of wage labor, and the impact of immigration and industrialization as powerful factors in shaping a dominant white supremacy. ${ }^{9}$ Other scholars whose research addresses the history of leisure and tourism have focused their attention on public amusements and other popular culture attractions to highlight the dark undercurrent of racism and vigilantism that pervaded and often policed these important nineteenth-century venues. ${ }^{10}$ Yet, while most of these works detail the national

Boycotts and African American Citizenship in the Era of Plessy vs. Ferguson (Chapel Hill, 2010); Judith Giesberg, Army at Home: Women and the Civil War on the Northern Home Front, (Chapel Hill, 2009); Kate Masur, An Example for All the Land: Emancipation and the Struggle Over Equality in Washington, D.C. (Chapel Hill, 2010). Thomas Sugrue's sweeping survey of Civil Rights in the North gets us closer to understanding how segregation functioned in various spheres of everyday life, but he does not begin his look at the "Long Civil Rights Movement" until 1920. Thomas Sugrue, Sweet Land of Liberty: The Forgotten Struggle for Civil Rights in the North (New York: Random House, 1920).

${ }^{8}$ George Frederickson, The Black Image in the White Mind: The Debate on Afro-American Character and Destiny, 1817-1914 (New York, 1971) Masur, An Example for All the Land; William Gillette, Retreat from Reconstruction, 1869-1879 (Baton Rouge, 1979); Saidiya Hartman, Scenes of Subjection: Terror, Slavery, and Self-Making in Nineteenth Century America (New York, 1997); Kirt H. Wilson, The Reconstruction Desegregation Debate: The Politics of Equality and the Rhetoric of Place, 1870-1875 (East Lansing, 2002); Douglas Blackmon, Slavery by Another Name: The Re-Enslavement of Black People from the Civil War to WWII (New York, 2008); David Roediger, The Wages of Whiteness: Race and the Making of the American Working-Class (New York, 1991).

${ }^{9}$ Although not all of the authors mentioned in the following list of works would classify themselves as "whiteness scholars," they have each focused on the inner workings and public affirmations of white supremacy in the nineteenth-century North. Joanne Pope Melish, Disowning Slavery: Gradual Emancipation and "Race" in New England, 1780-1860 (Ithaca, 1998); Benjamin Reiss, The Showman and the Slave: Race, Death, and Memory in Barnam's America (Cambridge, 2010); Alexander Saxton, The Rise and Fall of the White Republic: Class Politics and Mass Culture in Nineteenth Century America (London and New York, 1990); Roediger, The Wages of Whiteness; Matthew Frye Jacobson, Whiteness of a Different Color: European Immigrants and the Alchemy of Race (Cambridge, 1999); Noel Ignatiev, How the Irish Became White (New York, 1995); Thomas C. Holt, "Racism and the Working Class," International Labor and Working-Class History, 45 (1994); Andrew Neather, “ 'Whiteness' and The Politics of Working-Class History," Radical History Review, 61 (1995); Jerome Bjelopera, City of Clerks: Office and Salesworkers in Philadelphia, 1870-1920 (Urbana, 2005).

${ }^{10}$ Historians have often treated African Americans as the objects of public ridicule and consumer exploitation, while also suggesting that Jim Crow policies permanently segregated blacks from northern leisure venues. See, Myra B. Armstead, "Lord Please Don't Take Me in August": African Americans in Newport and Saratoga Springs, 1870-1930 (Chicago, 1999); Bjelopera, City of Clerks; Nasaw, Going Out; and Cocks, Doing the Town. 
manifestations of a culturally potent white supremacy, they often obscure more than they reveal the everyday political workings and intellectual disputes of segregation.

This study tells a different story about the making of segregation in the post-Civil War North by considering the many constituent groups and political interests that coalesced to create and contest segregation at the Jersey shore. It agrees in many ways with recent Reconstruction-era scholars who argue that competing notions of political economy, and not an all-encompassing white supremacy, framed racial politics in the postwar North. As Eric Foner, David Quigley, and Amy Dru Stanley have argued, a commitment to free labor ideology enabled white northerners to discredit the Civil Rights platform of Radical Republicans and black political leaders without resorting to political violence or racist rhetoric. ${ }^{11}$ As a result, white northerners derived comfort from their ability to contain the presence of African Americans in social arenas not already desegregated by wartime emancipation and Reconstruction politics.

"The Retreats of Reconstruction" extends the plot of these important works by analyzing the ways in which white and black northerners debated notions of freedom and citizenship through the newly problematic meanings of consumption. Beginning in the 1880s, commercialized leisure options challenged long-standing conceptions of political economy, forcing businessmen, politicians, and marketing agents at the Jersey shore to confront a unique public setting that defied common segregationist practices. Thus, while others have insisted that the mere presence of African Americans in public space produced segregation, I argue that the rise of mass consumption as a guiding principle of

\footnotetext{
${ }^{11}$ Heather Cox Richardson, The Death of Reconstruction: Race, Labor, and Politics in the Post-Civil War North, 1865-1901 (Cambridge, 2001); Amy Dru Stanley, From Bondage to Contract: Wage Labor, Marriage, and the Market in the Age of Slavery Emancipation (Cambridge, 1998).
} 
economic growth, and the debates about political economy that it spurred-intertwined with the ideologies that led to Jim Crow segregation at the Jersey shore.

In a society that had long been organized around production rather than around consumption, whites and blacks offered competing definitions of what being a free consumer meant. White working-class tourists argued that the rights of consumers should be determined by a group's aggregate spending power and sought to persuade business owners that the only path toward peace and profits was through segregation. Black workers protested and boycotted whites' segregationist policies because of their own beliefs about consumption. In claiming their rights to integrated leisure, African Americans forced business owners and other public officials to decide whether the right to consume was equal to the right to work. Did business have the right to exclude African American consumers on account of race, and if so, was a market-based defense capacious enough to justify the refusal of service without acknowledging racial prejudice?

In recent decades, a growing body of literature has examined the relationship between citizenship and consumption during the nineteenth century. Joanna Cohen and William Leach have explained how nineteenth-century retailers and consumers challenged republican visions of a producer-oriented society. ${ }^{12}$ In contrast, Jackson Lears and Daniel Horowitz have stressed the social anxieties that a free consumer society

\footnotetext{
${ }^{12}$ My question, "Is the right to consume equal to the right to work?" is adopted from Joanna Cohen's statement about consumption in the antebellum era: "The right to purchase is as free as the right to sell." Joanna Cohen, "The Right to Purchase is as Free as the Right to Sell: Defining Consumers as Citizens in the Auction-House Conflicts of the Early Republic," Journal of the Early Republic 30.1 (2010): 25-62. For works that detail the rise of consumption in the eighteenth and nineteenth century, see esp. T.H. Breen, The Marketplace of Revolution: How Consumer Politics Shaped American Independence (Oxford, UK, 2004); Drew McCoy, The Elusive Republic: Political Economy in Jeffersonian America (Chapel Hill, 1980); Richards L. Bushman, The Refinement of America: Persons, Houses, Cities (New York, 1992); Richard Butsch, For Fun and Profit: The Transformation of Leisure into Consumption (Philadelphia, 1990); Richard Wightman Fox and T.J. Jackson Lears, eds., The Culture of Consumption: Critical Essays in American History, 1880-1980 (New York, 1983); and Roy Rosenzweigh, Eight Hours for What We Will: Workers and Leisure In An Industrial City, 1870-1920 (Cambridge, 1983); William Leach, Land of Desire: Merchants, Power and the Rise of a New American Culture (New York, 1994).
} 
created for Progressive-era cultural elites. ${ }^{13}$ In their coverage of civil rights and suffrage campaigns, Lawrence Glickman, Blair Kelley, Margaret Finnegan, and Nan Enstad explain how consumer issues became central to black and female activists' workplace disputes. ${ }^{14}$ However, most of these works document the role of non-consumption, focusing on labor boycotts and national campaigns for consumer protection. Few studies explore the relationship between consumer rights and blacks' claims to integration during the early Jim Crow period. Instead, historians have reserved such treatments for the Civil Rights Movement of the 1950s and 1960s, when, as the story goes, black protestors joined a long line of political activists who learned to think like consumers. ${ }^{15}$

The New Jersey shore is an ideal setting to challenge these assumptions because it attracted a wide variety of northern citizens - white and black - as well as some from the South — who regularly debated the rights of consumers in determining the legality of segregation during the Reconstruction era. As John Sterngrass astutely observes, leisure

\footnotetext{
${ }^{13}$ T.J. Jackson Lears, No Place of Grace: Antimodernism and the Transformation of American Culture, 1880-1920 (New York, 1981); Daniel Horowitz, The Morality of Spending: Attitudes Towards the Consumer in America, 1875-1940 (Chicago, 1992).

${ }^{14}$ Lawrence Glickman, Buying Power: A History of Consumer Activism in America (Chicago, 2009); Kelley, Right to Ride; Margaret Finnegan, Selling Suffrage: Consumer Culture and Votes for Women (New York, 1999); Nan Enstad, Ladies of Love, Girls of Adventure: Working Women, Popular Culture, Labor Politics at the Turn of the Century (New York, 1999); Grace Elizabeth Hale, Making Whiteness: The Culture of Segregation in the South, 1890-1940 (New York, 1998).

${ }^{15}$ African American consumer history usually begins during the Great Migration and pays particular attention to black boycotts. Richard Weem's Desegregating the Dollar is one of the few studies that date the African-American movement for what I term "free consumption" to the turn-of-the-century. Richard Weems, Jr., Desegregating the Dollar: African American Consumerism in the Twentieth Century (New York, 1998). For examinations of black consumer boycotts during the twentieth century see esp. Cheryl Greenberg, "Don't Buy Where You Can't Work," in Lawrence Glickman, eds, Consumer Society in American History: A Reader, (Ithaca, 1999): 241-276; Andor Skotnes, " "Buy Where You Can Work: Boycotting for Jobs in African American Baltimore, 1933-1944," Journal of Social History 27 (1994): 73562; Julia Kirk Blackwelder, Styling Jim Crow: African American Beauty Training during Segregation (College Station, TX, 2003); Darlene Clark Hines, "The Housewives League of Detroit: Black Women and Economic Nationalism," In Visible Women: New Essays on American Activism, edited by Nancy A. Hewitt and Suzanne Lebsoc (Urbana, 1993): 223-41; Stephanie Shaw, What a Woman Ought to Be and Do: Black Professional Women Workers During the Jim Crow Era (Chicago, 1995); and Chip Rhodes: "Writing Up the New Negro: The Constitution of Consumer Desire in the Twenties," Journal of American Studies 28 (1994): 191-207.
} 
settings offer rare opportunities to study otherwise repressed changes in society because visitors and local officials often feel "freer to challenge prevailing norms, exercise their fantasies, expand their horizons, and live their aspirations." ${ }^{\prime 16}$ The men and women who helped build and promote the Jersey Shore in the early years of Reconstruction attempted to do just that, engaging in an ambitious campaign to move the nation, and public leisure settings in particular, beyond the narrow class-based and racially restrictive boundaries of the pre-Civil War era.

At the same time, the unfinished political challenges of Reconstruction, as well as the financial liabilities that accompanied such bold progressive undertakings, remind us that white consumers also shaped the implementation of segregation in the post-Civil War North. Spurning earlier attempts by business owners to tolerate black tourists on beaches and boardwalks, white tourists used their power as consumers to shape the racial and social boundaries of northern vacation destinations. Under pressure to respond to their complaints, local authorities adopted a variety of temporary measures throughout the late 1880 s to forestall more drastic racial policies. In Asbury Park, the town's Mayor and founding father James Bradley began by instituting "clock-time segregation," a move that asked black patrons to postpone their leisure time on area boardwalks until after 10:30pm. Meanwhile, Atlantic City officials responded to appeals to harden segregation laws by asking black tourists to accept "seasonal segregation," inviting black tourists to visit the popular resort at the end of the summer season. After both of these policies failed to appease white tourists or to prevent African Americans from violating these restrictions, local officials moved by 1893 to enforce their ignored segregation notices.

\footnotetext{
${ }^{16}$ Sterngrass, First Resorts, 3.
} 
The inability of white officials to police the color line through informal demands and polite requests underscores the political anxieties northern politicians and business owners held regarding race and public space after the Civil War. As the early struggle to define segregation at the Jersey shore proved, the postwar politics of Jim Crow required that white officials honor and protect the emancipationist legacy of Union victory by regionalizing race as a southern problem. The unwillingness of many white tourists to enjoy their leisure alongside African Americans forced business owners and politicians to adopt an unpopular and unsuccessful middle ground when it came to segregation notices. Highly adept at reading the hidden transcripts of Jim Crow, African Americans "jumped Jim Crow" by cleverly ignoring and side-stepping unofficial public notices that they believed lacked authoritative consent. ${ }^{17}$ In adopting an informal tone of polite appeals and respectful pleas, local authorities advertised the illegitimacy of their requests. ${ }^{18}$ Their guarded hesitancy to adopt more stringent polices and the boldness of African American protests remind us that an emphasis on white supremacy and official public notices often obscure more intricate maneuverings of a color line that was rarely so black and white.

Forced to implement a firmer approach to marketing and managing segregation by 1893 , local officials appealed to the laws of the marketplace to defend their consolidated social boundaries. As a policy referendum on consumer rights and market

\footnotetext{
${ }^{17}$ My conceptual understanding of infrapolitics and "hidden-transcripts" is drawn from the work of Michel de Certeau, Robin G. Kelley, Stephen Hahn, and James C. Scott. See, Michel de Certeau, The Practice of Everyday Life (Berkeley, 1984); Robin D.G. Kelley, Race Rebels: Culture, Politics, and the Black Working Class (New York, 1994); Stephen Hahn, A Nation Under Our Feet: Black Political Struggles in the Rural South from Slavery to the Great Migration (Cambridge, 2003); James C. Scott, Domination and the Arts of Resistance: Hidden Transcripts (New Haven, 1992).

${ }^{18}$ Elizabeth Abel's study of Jim Crow signs in the postwar South is particularly useful in gaging what constituted legitimate and illegitimate forms of segregation notices. As Abel points out, signs that were handwritten, lacked proper grammar, or appealed to folkish traditions, were often seen as invalid and fraudulent since they betrayed the official-state sanctioned authority and conformity necessary to compel obedience. Elizabeth Abel, Signs of the Times: The Visual Politics of Jim Crow (Berkeley, 2010).
} 
principles, Jersey shore segregationists argued that Jim Crow boundaries were permissible in a service economy because they protected the property rights of business owners and defended the public welfare against working-class consumer protesters who threatened to undermine the economic prosperity and social preferences of others. In 1887, defenders of Asbury Park's recently segregated bathing facilities proclaimed that segregation was implemented not to harass black patrons, but to protect instead the financial welfare of business owners from "colored people who are doing their utmost to ring the projector and patrons of that resort into odium contempt." ${ }^{, 19}$ Defending James Bradley's policies later that summer, correspondents for the New York Times echoed the town's sentiments, explaining that "Mr. Bradley has had so much to do with the growth of Asbury Park" that his "interests in it and his stake in its prosperity are at all events much larger than those of anybody else."20

The philosophical consensus that emerged from these Jim Crow contests highlights the emergence of a subtler — yet no less enduring — strand of racism that grew out of the everyday concerns of business owners and local boosters. During the 1880s and 1890 s, an increased faith in the market replaced a waning faith in racist rhetoric to police black behavior. In rebranding Jim Crow as a product of market forces, commentators and local officials embraced this change as a contrast to an older racism that was direct, visceral, and easily recognizable. To sanction these changes within an existing market order, local business owners reworked nineteenth-century ideas about the common law that historically subordinated the property rights and profit-motives of

\footnotetext{
19 "The Color Line at Asbury Park," The Sun (NY), June 29, 1887.

20 “Africa and Asbury Park," New York Times, July 7, 1887.
} 
businessmen to the "people's welfare. ${ }^{, 21}$ As a developing free consumer ideology became synonymous with economic freedom in the late-nineteenth century, the need to protect citizens and travelers from profit-seeking schemers became less important. Between 1893 and 1900, Jersey shore segregationists marketed a reworked common law tradition as a pro-business and race-neutral solution to the complicated web of interests groups that comprised a mass consumer society. This new strategy gave them confidence that in future segregation debates, the need to protect the profitability of popular leisure spaces from political activists would be equal to ensuring the "people's welfare." This story is familiar to scholars of the post-WWII Civil Rights era, when consumer protests moved to the center of America's political economy. ${ }^{22}$ Yet as early as the late-nineteenth century, northern whites were working hard to disassociate business decisions from personal opinions in a leisure industry that embraced a consumer-based model of economic growth far earlier than the rest of the nation.

African Americans challenged these claims by arguing that the right to consume was equal to the right to property. In calling for a free consumer society, they remarked that efforts by whites to shroud their segregation policies in market-based language only reified the hierarchy of race in the late-nineteenth century. "Race prejudice," black leaders noted, is "still unconquerable even in the North, and by religious influences

\footnotetext{
${ }^{21}$ William Novak reminds us that for much of the nineteenth century, the promotion of a "well-regulated" society trumped the primacy of property rights, which were "social, relative, and historical, not individual, absolute, and natural." William Novak, The People's Welfare: Law and Regulation in Nineteenth Century (Chapel Hill, 1996). For a look at how race and the law was impacted by common law ideas, see, Barbara Welke, 'When All Women Were White, and All the Blacks Were Men: Gender, Class, Race, and the Road to Plessy, 1855-1914," Law and History Review, 13.2 (1995); A.K. Sandoval Strauss, "Travelers, Strangers, and Jim Crow: Law, Public Accommodations, and Civil Rights in America," Law and History Review, 23.1 (2005).

${ }^{22}$ For a sampling of post WWII desegregation efforts, see esp. Thomas Sugrue, The Origins of the Urban Crisis: Race and Inequality in Postwar Detroit, (Princeton, 1996); Martha Biondi, To Fight and Stand: The Struggle for Civil Rights in Postwar New York City, (Cambridge, 2003); Gary Gerstle, Race and the Myth of the Liberal Consensus," Journal of American History, 82.2 (September, 1995); Lizabeth Cohen, A Consumer's Republic: The Politics of Mass Consumption in Postwar America (New York, 2003).
} 
exerted in the very denominations of Christians to which the colored people generally belong." ${ }^{23}$ To those who participated in civil rights demonstrations at the Jersey shore, such pronouncements spearheaded their attempts to reframe the economic rights of consumers and to protect the common law tradition. ${ }^{24}$ When rhetorical counterattacks failed, black protesters staged a series of consumer protests on boardwalks, inside hotel dining rooms, and by picketing amusement venues that denied them entry; actions that helped to secure them readmission to public space and access to a world of goods. These protests were successful because they circumnavigated the segregation debate, trading a hostile political vocabulary, "social equality," for one focused on consumer rights, a language that was becoming increasingly more difficult for white audiences and local officials to refute. Thus, rather than reject capitalism, black activists worked within the ideological parameters of the market system, deploying political spectacles to make the consumer marketplace accessible for all participants.

The public nature of these campaigns threatened the finances of the targeted venues by linking local events to a national discussion of segregation. Through black consumers' appeals for racial justice and free consumption, interested Americans looked to the events of Asbury Park and Atlantic City as justifications for and against segregation in their own communities. Northern periodicals, the African American press, and citizens as far south as Georgia intensified their coverage of the Jersey shore's segregation debate as a result of the publicity created by the region's civil rights demonstrators. While northern whites denounced the coverage that these protests

\footnotetext{
${ }^{23}$ In a political rally held in Asbury Park in 1887, Reverend John Frances Robinson of Asbury Park exclaimed to an interracial audience, "The Colored man now has the same rights as the white man, including the right to walk on the beach of Asbury Park." The Sun (NY), June 29, 1887.

24 "Denouncing Mr. Bradley: The Colored People of Asbury Park Resent the Slurs of Its Founder," The Sun (NY), June 28, 1887.
} 
garnered, southern segregationists used northern headlines to embarrass and humiliate northern progressives. In 1892, a Georgia congressman routinely referenced the segregation debate at the Jersey shore to support a bill legalizing segregation in southern public schools, asking both southern and northern opponents of segregation whether "prejudice against the Colored people is peculiar to the South?"25

The success of these campaigns speaks significantly to the centrality of labor in framing the politics of Jim Crow. The willingness of local merchants and political officials to appease black protestors and re-admit them to area resorts throughout the 1880s and early 1890s underscores the central role played by black workers during these years. While many discriminatory practices denied black laborers access to safe and lucrative work during the late-nineteenth century, the availability of service work offered seasonal workers uncommon political possibilities in a consumer-driven economy; opportunities they used to engage in a continuous series of public demonstrations and an untold number of infrapolitical acts that adds to what we know about the rise of the "citizen consumer" in American politics. ${ }^{26}$ Indeed, black occupations of consumer venues and commercial spaces left them virtually alone among Reconstruction-era consumer activists in lobbying for an unregulated marketplace. Unlike traditional boycotts, which were often waged to enact workplace changes or secure product safety, acts of civil disobedience on the Jersey shore attempted to fundamentally alter ideas about political economy. ${ }^{27}$ Black protestors who organized "wade-ins" on local beaches and refused to

\footnotetext{
${ }^{25}$ New York Times, "The Color-Line in School: An Effort to Draw it Sharply in Georgia," July 26, 1887.

${ }^{26}$ The term "citizens consumer" has become synonymous with Lizabeth Cohen's study of twentieth century consumer politics. This study, however, dates the origins and uses of the term to the Gilded Age, when black consumer activists pushed for a political culture that embraced unregulated and freely accessible consumption for all citizens. Cohen, A Consumer's Republic.

${ }^{27}$ In the 1970s, scholars began to chart the ways that citizens shifted their identity from workers to consumers through a series of strikes, boycotts, and national campaigns for product regulation. Although
} 
leave amusement venues were not lobbying for wage increases, more humane workplace treatment, or regulations on food and drugs-although they participated in these campaigns as well. Instead, in both their strategic objectives and tactical maneuvers, public occupations of consumer venues aimed to transform the legal boundaries and social accessibility of the postwar marketplace by threatening the financial solvency and political legitimacy of local business owners.

Yet these labor patterns and the long-term effects of civil rights protests also provide telling reminders about the limits of integration in the early Jim Crow era. In the early 1900s, stagnant wages, labor competition, and progressive era anti-vice crusades, reduced the willingness of white businesses to hire black workers, leading some black residents and political leaders to doubt the practicality and sustainability of civil disobedience. In response, black civic leaders, entrepreneurs, and investors called on black workers and tourists to boycott the region's white-owned leisure marketplaces and build their own inclusive resort and entertainment districts. By the 1920s, AfricanAmerican boycotts of Jim Crow facilities enabled black capitalists to build a thoroughfare of hotels, shops, and cheap amusements to meet the housing, labor, and social demands of black consumers.

Through these entrepreneurial and consumer focused initiatives we learn about the diverse efforts that black communities undertook to respond to and transcend

this study also details boycotts and other forms of labor activism undertaken by black workers, it situates the black consumer movement at the Jersey shore at a critical juncture in the nation's transition from a free labor to a free consumer society. For works that document the link between consumer advocacy and labor rights, see esp. Erna Agnevine, Roots of the Consumer Movement: A Chronicle of Consumer History in The Twentieth Century (Washington, D.C., 1979); Lawrence Glickman, A Living Wage: American Workers and the Making of Consumer Society (Ithaca, 1997); Rosenzweig, Eight Hours for What We Will; David Montgomery, Beyond Equality: Labor and the Radical Republicans, 1862-1872 (New York, 1967); Michael Gordon, "The Labor Boycott in New York City, 1880-1886," Labor History 16 (Spring 1975): 184-229; and Daniel R. Ernst, "Free Labor, The Consumer Interest, and the Law of Industrial Disputes, 1885-1900,” American Journal of Legal History 36 (January 1992): 19-37. 
segregation during the early Jim Crow era. While much of the scholarship on intraracial civil rights debates during what Rayford W. Logan famously termed the "nadir," focus on class tensions and disagreements over morality; we learn that at the Jersey Shore, these exchanges eventually yielded to the pressures of black consumer demand and the economic motives of local black entrepreneurs. ${ }^{28}$ By the mid-1890s, the financial and cultural effects of Jim Crow's reach taught even the most conservative of black leaders that traditional racial uplift strategies could not effectively meet the basic requirements of the most vulnerable African American citizens in the modern consumer marketplace. In boycotting Jim Crow spaces, black capitalists took the opportunity to reaffirm their commitment to hard work and responsible recreation but did so within the consumerdriven demands of a developing black marketplace that also valued fraternal comfort and personal style. In reminding whites that the Jim Crow system presided over a racially regulated and unequal market economy, black business owners and investors used their own leisure spaces to publicize a more equal and accessible vision of a free consumer society. Black cottage owners in Asbury Park, for example, inscribed "Equal Rights" on their signs, announcing that while black businesses were primarily designed to meet the needs of African American customers, members of all races and classes were welcome. ${ }^{29}$

\footnotetext{
${ }^{28}$ Rayford W. Logan, The Negro in American Life and Thought: The Nadir, 1877-1901 (New York, 1954). See also, Evelyn Brooks Higginbotham, Righteous Discontent: The Women's Movement in the Black Baptist Church, 1880-1920 (Cambridge, 1993); Kevin Gaines, Uplifting the Race: Black Leadership, Politics and Culture in the Twentieth Century, (Chapel Hill, 1996); Willard B. Gatewood, Aristocrats of Color: The Black Elite, 1880-1920 (Fayetteville, 2000; Mitchel, Righteous Propagation: African Americans and the Politics of Racial Destiny after Reconstruction (Chapel Hill, 2004). Works that detail these divisions in leisure communities include, Mark S. Foster, " 'In the Face of Jim Crow': Prosperous Blacks and Vacations, Travel, and Outdoor Leisure, 1890-1945," Journal of Negro History 84 (Spring 1999); Andrew W. Kahrl, “'The Slightest Semblance of Unruliness': Steamboat Excursions, Pleasure Resorts, and the Emergence of Segregation Culture on the Potomac River," The Journal of American History 94.4 (March 2008); and Armstead, "Lord Please Don't Take Me in August."

${ }^{29}$ Reverend T. Gould, The Christian Recorder, August 11, 1890.
} 
But as hotels, restaurants, and an assortment of "low resorts" sprung up "behind the color-line," white authorities scrambled to crackdown on these areas that many had long linked to moral depravity and political corruption. In Atlantic City, efforts to clean up Jim Crow followed standard Reconstruction-era practices as vice raids and congressional hearings touted the immorality of black leisure and publicized rampant electoral fraud as emblematic of interracial political alliances. In Asbury Park, however, local officials urged citizens to support commercial development and modern municipal improvements by ending segregation. Confronting an urgent sanitation crisis that endangered the health of black residents and forestalled commercial development in the city, white and black officials called on the city to annex the territory of black homes and businesses known as the "West End" and to officially end segregation in the stagnant resort town.

In a political campaign that often pitted whites against whites, the decision to annex the West End became a contentious discussion about the long-term social and economic effects of environmental racism and African-American fitness for selfgovernment. Opponents of segregation, led by ousted Mayor James Bradley, claimed that consolidating the West End would shift the tax burden onto whites and corrode the social and political profile of the beach resort. Annexationists, however, denounced these attacks for allowing "a prejudice of long standing" to impede future commercial progress and endanger the public's safety. As an indictment of segregation's political economy, annexation's passage in May 1906 ensured the potency of a new consumer movement that linked the public health of consumers and consumer districts to political stability and 
economic prosperity. ${ }^{30}$ Just as important, these environmental contests highlighted the new role that government entities served in negotiating the debate between consumption and segregation. While other northern metropolitan areas were undertaking measures to seize black property throughout the early twentieth century, Asbury Park's annexation victory served notice to local black activists that even within such highly charged racial times, a shared commitment to environmental justice, consumer safety, and municipal efficiency could defeat segregation. ${ }^{31}$

What began as a consideration over the place of African Americans in the public sphere became a wide-ranging discussion about the rights and health of consumers and the role of consumption in the struggle against segregation. Unlike other postwar northern communities during the Reconstruction era, the implementation and eradication of segregation laws at the Jersey shore was not decided by state legislatures, local judges, or by retaining and enforcing antebellum era racial customs. Instead, it was a cadre of businessmen, marketing agents, local politicians, white and black tourists, and workingclass residents who helped shape segregation policy and ideas about citizenship and economic freedom for summer pleasure-seekers. The contentious political and social

\footnotetext{
30 "Bradley Is Only Opponent," Asbury Park Evening Press, March 20, 1906; Asbury Park Evening Press, "Annexation Demanded," February 17, 1906.

${ }^{31}$ Khalid Muhammad, Kevin Mumford, Marcy Sacks, and Andrew Kahrl remind us of the serious efforts whites pursued to police and control black leisure spaces in the early 1900s. Khalil G. Muhammad, The Condemnation of Blackness: Ideas About Race and Crime in the Making of Modern Urban America (Cambridge, 2010); Kevin Mumford: Interzones: Black/White Sex Districts in Chicago and New York in the Early Twentieth Century (New York, 1997); Marcy S. Sacks, " 'To Show Who Was in Charge': Police Repression of New York City's Black Population at the Turn of the Twentieth Century," Journal of Urban History 31 (September 2005): 799-819; Andrew Kahrl: The Land Was Ours: African American Beaches from Jim Crow to the Sunbelt South (Cambridge, 2012). For studies that link environmental inequality to public policy, as well as African-American attempts to combat public health deficiencies in black communities, see esp. Robert D. Bullard, Dumping in Dixie: Race, Class, and Environmental Quality (Boulder, CO, 1990); Diane D. Grave and Mark Stoll, "To Love the Wind and the Rain": African Americans and Environmental History (Pittsburgh, 2006); Andrew Hurley, Environmental Inequalities: Class, Race, and Industrial Pollution in Gary, Indiana, 1945-1980 (Chapel Hill, 1995); and Julie Sze, Noxious New York: The Racial Politics of Urban Health and Environmental Justice (Cambridge, 2007).
} 
motives of each of these constituencies made it difficult to ensure a uniform segregation policy while also maintaining the peaceful profile of a summer resort. These unique circumstances provided black tourists and seasonal workers with uncommon political possibilities in an era of expanding Jim Crow laws. By making consumer rights and public health central to the struggle against segregation, African Americans did more than just challenge the cultural authority of white supremacy. They moved as consumer activists, and later as entrepreneurs and environmental advocates, to contest and sometimes defeat the imposition of Jim Crow in the post-Civil War North, making leisure a critical battleground in a national campaign for civil rights, market fairness, and environmental justice.

This project utilizes a diverse collection of printed and visual material to document the politics of segregation. Because many beach towns relied on informal Jim Crow laws, legal documents and public records, including legislative battles and official records, are mostly nonexistent. A careful reading of newspaper accounts and local advertisements, however, reveals the hidden transcripts of segregation politics, including the rebellious acts of black activists. To document the marketing strategies and policing tactics that whites incorporated to create and maintain Jim Crow boundaries, I have also consulted local promotional materials, and where available, area court proceedings. These records help trace the history of segregation laws in the region, and lay out the ideological parameters of the segregationist platform. In uncovering the linguistic and vernacular interplay between ideas and policies, this study is able to better reveal the "epistemologies of ignorance" that mapped race on the beach, allowing scholars of 
leisure and civil rights, as Elizabeth Abel mentions, to more acutely "determine the visible field" of race, to "call it out where it is silent, to erase it where it is salient, and to invest it with the burden of history. ${ }^{, 32}$ Nowhere is this more important than when examining the understudied history of northern Jim Crow signs, and the accompanying tactics African Americans utilized to resist them.

Information on the construction of black-owned leisure accommodations is pulled from board of trade publications, promotional pamphlets, and advertisements. These sources provide insight into the financial maneuverings of black entrepreneurs and the challenges these men and women faced in securing economic independence, fraternal autonomy, and free cultural expression during the early Jim Crow period. In turn, these and other public records, including press coverage of vice raids, campaign speeches, and progressive era poverty studies relate the efforts of northern whites to control black neighborhoods and consumer districts, as well as the successful campaign by black activists in Asbury Park to tie environmental justice and consumer rights to a broader movement for racial equality. In the age of Plessy, these political struggles over integrated leisure reveal the ideological and legal dilemma that continued to confront capitalists and civil rights activists in the Jim Crow North.

What I term the "politics of segregation" then, encompassed a cornucopia of symbols, texts, riots, sit-ins, boycotts, electoral campaigns, spatial mappings, and pedagogical instructions. Through these political battles we witness a post-Civil War Civil Rights movement coming to grips with the unresolved disputes of Reconstruction, and a consumer society whose local political leaders often struggled to appease a

\footnotetext{
${ }^{32}$ Shannon Sullivan and Nancy Tuana, Race and the Epistemologies of Ignorance, eds. (New York, 2007); Abel, Signs of the Times, xviii.
} 
democratic base severely fractured by competing political, social, and economic agendas. The outcome of these contests would form the basis from which a Jim Crow culture and political landscape would be made and remade following Reconstruction, as white and black northerners interacted with each other as workers and tourists during summers at the seashore. 


\section{Chapter 1: The Struggle to Define Segregation, 1861-1893}

During the late-nineteenth century, one did not need to live in the South to be confronted with the familiar question of "what to do about the colored problem?" In the summer of 1890, a Philadelphia reporter dispatched to Atlantic City interviewed white tourists about ongoing racial tensions publicized in the local press. Describing the insistence of many working-class blacks to demand admission to commercial leisure spaces, most whites explained that while black workers often responded, "Alright, boss" when told "you can't sit here," when it came to removing themselves from amusement rides and other recreational venues "they draw the line at the flying horses...If the flying horse goes they go on it, much to the disgust of the would-be exclusive patron."1 With this statement, white tourists expressed a common political complaint about the ambiguities of social space and economic rights in Reconstruction-era leisure settings. For much of the nineteenth century, social protocol dictated that service workers remain cheerful, deferential, and anonymous in the presence of white guests and tourists. The decision by African American workers to demand access to both public and private leisure spaces during their free time disrupted these guidelines and unsettled longstanding northern segregation practices.

Before the Civil War, racial disputes over access to public accommodations were often solved through violence, popular minstrelsy, and the politics of free labor, strategies and tactics that by 1877 had enabled white northerners to successfully contain the recreational and consumer behavior of African Americans. But beginning in the 1880s, a number of demographic changes and business decisions altered northern segregation policies. The growing popularity of the Jersey shore and the convenience of local

\footnotetext{
1 "Negro by the Sea," Philadelphia Times, July 25, 1890.
} 
consumer and leisure attractions brought local black workers into public and commercial leisure spaces in significant new ways. Unlike the North's black elite, who often enjoyed their leisure time in private social spaces, black workers consistently ignored traditional social customs and public notices and insisted on their rights as free citizens to purchasable leisure and entertainment. With money to spend and expanded leisure hours, they took seats on boardwalk benches, spent their free time riding cheap amusements, changed alongside whites in bathhouses, and sunbathed on area beaches in the afternoon. Despite public notices asking them to "please refrain" from such activities, many openly defied these requests and engaged in repeated acts of disobedience that contributed to the racial volatility of the region's public and commercial landscape.

Yet the ambiguity of the region's segregation policy reflected more than the mere presence of black workers. Instead, the increased racial hostility reflected in part the changing social demographics of white crowds during the Reconstruction period. Campaigns for "eight hours for what we will," improvements in modern travel, and the promotion and proliferation of middle-class beach resorts, brought an untold number of white working-class tourists to northern vacation settings in the 1870 s and 1880 s. In response to what they perceived to be the arrogance of black workers, working-class whites called on local authorities to restrain the public behavior and consumer activities of black working-class residents and to officially institute segregation at the Jersey shore. Surprisingly, white business owners often ignored their demands for segregation. For business owners, this decision reflected an acknowledgement that as late as the 1880 s, the question of who constituted a free consumer was controversial and still unsettled. Acutely aware of the economic liabilities that such a divisive political debate could pose, they 
consciously avoided engaging white and black workers in their disputes, a debate they believed threatened to overturn critical marketplace principles, transform long-standing social boundaries, and antagonize black workers in a service economy with limited labor alternatives.

Underpinning these disputes is a broader question about the role of class and the usefulness of racist discourse in enforcing segregation. For many years, historians have emphasized the continuation of racist feelings in shaping segregation in the post-Civil War North. ${ }^{2}$ Yet while white supremacist rhetoric survived the war and aided the claims of white tourists, it was also class tensions between white business owners and white tourists that contributed to the region's undefined segregation policy. Unsure of how to employ the new racial language of the Reconstruction era in their promotional literature, in editorials, or on early segregation signs, local merchants and tourist promoters often avoided the overtly racist claims uttered by white tourists and tolerated a limited black presence. To both black and white consumers, their refusal to promote either full integration or official segregation was viewed as sign of weakness and came to reflect a postwar period where enforcement of the color line often appeared confused and unmanageable. In response, white tourists and black workers staked out their own political positions in promotional brochures, pamphlets, and editorials. These actions-

\footnotetext{
${ }^{2}$ This chapter maintains that historians have often taken racism for granted. For example, scholars who have documented the history of Jim Crow in the North have assumed that very little changed between the antebellum era and the hardening of Jim Crow during the Gilded Age. See, George Fredrickson, The Black Image in the White Mind: The Debate on Afro-American Character and Destiny, 1817-1914 (New York, 1971); William Gillette, Retreat from Reconstruction, 1869-1879 (Baton Rouge, 1979); Saidiya Hartman, Scenes of Subjection: Terror, Slavery, and Self-Making in Nineteenth Century America (New York, 1997); Kirt H. Wilson, The Reconstruction Desegregation Debate: The Politics of Equality and the Rhetoric of Place, 1870-1875 (East Lansing, 2002); Alessandra Lorini, Rituals of Race: American Public Culture and the Search for Racial Democracy (Charlottesville, 1999); Douglas Blackmon, Slavery by Another Name: The Re-Enslavement of Black People from the Civil War to WWII (New York, 2008); and David Roediger, The Wages of Whiteness: Race and the Making of the American Working-Class (New York, 1991).
} 
and the demographic changes and business decisions that precipitated them-were signs that local segregation policies were becoming increasingly tied to consumer opinion in the Jim Crow North. It was not surprising then, that the age of commercial leisure and mass consumption coincided with debates about segregation.

The Civil War spurred profound changes in the nation's popular culture, including the political conversation over leisure and popular summer amusements. As northern citizens coped with disruptions to the economy and the family, and struggled to understand draft riots and civil rights protests, local commentators debated who should use, control, work, and enjoy these tourist sites. Following a financially sluggish tourist season in 1861, the New York Herald noted that "war like time, tries all things, and it has tried the watering places pretty severely." ${ }^{3}$ While some observers optimistically reassured resort owners and businesses that "even civil war admits the possibility of people enjoying themselves," others were less hopeful. "We are afraid," some declared in June 1861, "this season will not be a very extensive or profitable one."

As business owners worried about the economic future of their beach resorts, shapers of northern popular opinion went about the work of transforming the social profile and business practices of summer resort communities. "This war of ours," the Herald declared, "is to revolutionize politics and politicians, to make the government stronger, to make the nation greater; to make business better and better conducted; to make us all more economical, prudent and steady—why may it not revolutionize fashion

\footnotetext{
3 "The Close of the Watering Season," New York Herald, September 22, 1861.

4 "The Watering Places," New York Herald, June 10, 1861; "Our Fashionable Summer Resorts-North and South," New York Herald, June 2, 1861.
} 
also?"5 For these individuals, the specter of civil war provided an opportunity to correct the abuses by landlords, which according to many critics ran "riot at watering place hotels. ${ }^{, 6}$ Throughout the mid-nineteenth century cultural critics complained that popular vacation sites like Saratoga Springs, Newport, and Sharon Springs had increasingly abandoned the democratic spirit of their earlier days by surrendering the "people's welfare" to profit, charging exorbitant rates that failed to correspond to the increasing income inequality of the Jacksonian age. The consequences of these business practices, many detractors maintained, created severe cultural ramifications that could not be allowed to survive the war. ${ }^{7}$ In particular, critics complained about the social climate of northern watering places that linked higher admission rates to the growing and pretentious "scepter of fashion" that forced "Jones to go because Smith went, and not because he liked it." In its wake, many northerners hoped that the "rule of as your neighbors do" would be replaced with the "rule of as you like."

By the summer of 1862 , many commentators noted with confidence the growing public distain toward Saratoga, Newport, and Sharon Springs, which seemed deserted as northern vacationers chose "retired spots along the coast" or in rustic outdoor retreats. ${ }^{9}$ "Fashion has succumbed to mars. The War has revolutionized the watering places," the Herald gleefully declared on August 23, 1863. "The war, which is reforming the manners, the dress, the society, the commerce, and the manufacturers, has reformed the fashionable also," elevating the "healthful retreat" to a place of cultural prominence,

\footnotetext{
${ }^{5}$ New York Herald, September 22, 1861.

6 "The Watering Places - Close of the Season," New York Herald, August 29, 1861.

7 “The Watering Places-Recreation and Retrenchment," New York Herald, June 17, 1862.

${ }^{8}$ New York Herald, September 22, 1861.

9 “"The Watering Places," New York Herald, April 7, 1862.
} 
while downgrading the preference for "artificial, enervating, corrupting" influences of northern watering places. ${ }^{10}$

By August 1863, the optimism of the previous summer faded as northern conservatives increasingly blamed displays of fashionable elitism on abolitionists and black domestic workers. According to several complaints, black domestic workers and servants were beginning to use wartime emancipation as a pretext to harass white tourists and negotiate larger gratuities from summer guests. ${ }^{11}$ Marking African American leisure workers as objects of fear and social disruption rather than amusement and comic relief signaled a profound shift in the racial dynamics of public amusements during the Civil War era. During the early years of the republic, theatrical depictions of the master-slave relationship were often violent and antagonistic. By the 1830s and 1840s, African Americans' recreational behavior and consumption habits began to undergo dramatic "cultural turns" as promoters of mass culture and working-class audiences dealt with changes wrought by gradual emancipation, industrialization, and immigration. ${ }^{12}$ Minstrel shows, carnivalesque comedies, and traveling exhibits portrayed free blacks on stage, as well as in political cartoons and artistic essays as social inferiors, whose bodies, movements, dialect, and cultural expressions represented a juvenile race that was to be mimicked, parodied, and pitied. These theatrical representations provided a retreat from the partisan politics of the Jacksonian age and the exploitation of wage labor, enabling a

\footnotetext{
10 "The Watering Place Season-New Developments," New York Herald, August 23, 1862.

11 "The Next Season at the Watering Places," New York Herald, April 21, 1863.

${ }^{12}$ Melinda Lawson, "Imagining Slavery: Representations of the Peculiar Institution on the Northern Stage: 1776-1860," Journal of the Civil War Era, 1.1 (March 2011): 25-55.
} 
divided working-class community to unite around the cultural authority of "whiteness" by lampooning "blackness."13

African Americans who participated in recreational outings in northern leisure settings received a much more hostile reception than black performers did inside minstrel theatres. In northern cities throughout the antebellum North, black aristocrats and middling folks were the victims of savage attacks from white gangs who viewed black leisure activities as a political reminder of the future of race relations during the era of gradual emancipation. Perhaps more than any other northern public venue during the era, leisure spaces became violent battlegrounds where whites and blacks routinely squared off, proving that while popular culture representations of blackness popularized a narrative of black subservience, the politics of the street signaled that whites viewed black intrusions into entertainment districts as a serious public danger to be solved by violent force.

In 1828, black couples emerged from coaches in Philadelphia to a mob of angry whites who attacked a handful of black women, stabbing their dresses with knives and shoving their dates into nearby gutters, while others frantically attempted to make their way into the night's feature event-a subscription ball for the city's black aristocracy. ${ }^{14}$

Six years later, white gangs attacked blacks attempting to ride a city carousel. Throwing

\footnotetext{
${ }^{13}$ The prevalence of racism in antebellum era popular culture is well documented. For a small sample of prominent works, see, Roediger, The Wages of Whiteness; Dale Cockrell, Demons of Disorder: Early Blackface Minstrels and Their World, (New York, 1997); Robert C. Toll, Blacking Up: The Minstrel Show in Nineteenth Century America (New York, 1974); Hazel Waters, Racism on the Victorian Stage: Representations of Slavery and the Black Character (Cambridge, 2007); Heather S. Nathans, Slavery and Sentiment on the American Stage, 1787-1861 (Cambridge, 2009); Errol G. Hill and James V. Hatch, A History of African American Theatre (New York, 2003); Eric Lott, Love and Theft: Blackface Minstrelsy and the American Working Class (New York, 1995); W.T. Lhamon Jr., Raising Cain: Blackface Performance from Jim Crow to Hip Hop (Cambridge, 1998); Alexander Saxton, The Rise and Fall of the White Republic: Class Politics and Mass Culture in Nineteenth Century America, (New York, 1990); Benjamin Reiss, The Showman and the Slave: Race, Death, and Memory in Barnum's America (Cambridge, 2001).

${ }^{14}$ Freedom's Journal, March 14, 1828.
} 
stones at black riders and demolishing the "flying horses," whites expanded their assaults to surrounding black communities, marching down city streets with clubs, stoning black couples out for an evening walk, and attacking the homes and churches of other black property owners with clubs and "brickbats" in a campaign one rioter described as "hunting nigs." Before city officials could contain the assaults, many local blacks fought back, defending their properties and their right to enjoy area leisure venues in a three-day riot that exposed the seriousness with which many ordinary whites approached black recreation. In an era in which the fate of whiteness was tied to the defense of slavery in the South, whites also viewed black leisure as a growing affront to the widening divisions within white society. ${ }^{15}$ Relating the events of the era, Philadelphia's popular press cautioned northern whites to be vigilant in maintaining clear divisions between consumers and workers. "How long will it be," the Pennsylvania Gazette asked, before “masters and servants change places?"16

Whites' violent punishment of blacks' leisure activities during the antebellum era shifted as popular culture representations of African Americans softened during the Civil War. Harper's Weekly, Frank Leslie's Illustrated Newspaper, political cartoons, and short stories each attempted to depict the anxieties of the northern mind toward the changing status of black Americans. While a variety of antebellum-era racial stereotypes permeated these artistic depictions, the war years also witnessed profound adjustments in the ways many northern whites viewed northern blacks. Ideas on racial injustice were

\footnotetext{
${ }^{15}$ Hazard's Register of Pennsylvania, 14, 1834, 126-128, 200-203, 265-266; See also John Runcie, “ 'Hunting the Nigs' in Philadelphia: The Race Riot of August 1834," Pennsylvania History, 29 (1972): 187218; Gary Nash, Forging Freedom: The Formation of Philadelphia's Black Community, 1720-1840 (Cambridge, 1988).

${ }^{16}$ Pennsylvania Gazette and Democratic Press, February 29, 1828; Pennsylvania Monthly Magazine, 2 (1828): 53-57.
} 
transformed as Union soldiers infiltrated the southern interior and black soldiers were proven to be capable and courageous defenders of their freedom. And, for the first time, wartime literature downplayed the popular image of "Sambo" by highlighting the courage of black soldiers. ${ }^{17}$

To many whites, though, acknowledging the accomplishments of black soldiers was much different then relaxing social and racial restrictions at leisure sites. After emancipation, whites used racial imagery not to amuse white audiences, but to warn them about the dangers of black civil rights intruding into spaces of leisure and recreation. As many northern critics charged, wartime emancipation allowed black waiters to preside over "ill-kept tables," while allowing others access to "gun contracts, ship charters, and government jobs."18 An editorialist at Saratoga Springs angrily noted that the "black waiters, who levy black mail upon all guests, must be taught to do their duty without the stimulus of extra postage," unless white business owners desire to see their watering places succumb to the "perpetual swindle" of black domestics. ${ }^{19}$ Threatening landlords to either "make a reform in these matters" or face public scrutiny, northern critics observed that the "carelessness of their blackamoors is one of the many pernicious results of the emancipation proclamation." ${ }^{20}$ To preserve the "future welfare and conduct of the nation - to say nothing of the comfort of ladies and success" of the summer vacation season, many white tourists lectured northern proprietors to instill harsher discipline on their black wait staff and initiate a more "thorough reform in the management of the

\footnotetext{
${ }^{17}$ Chandra Manning, What This Cruel War Was Over: Soldiers, Slavery, and the Civil War (New York, 2007); Kate Masur, "A Rare Phenomenon of Philological Vegetation: The Word "Contraband" and the Meanings of Emancipation in the United States," Journal of American History 93.4 (March 2007): 10501084, Alice Fahs: The Imagined Civil War: Popular Literature of the North and South, 1861-1865 (Chapel Hill, 2001).

${ }^{18}$ New York Herald, April 21, 1863.

19 "The Excitements of the Day: The War and the Watering Places," New York Herald, May 17, 1863.

20 "The Watering Places during the Dog Days," New York Herald, August 7, 1863.
} 
watering place hotels." If prices were to remain high, the Herald promised that "the public will not be satisfied" unless blacks were to be re-educated as to their place in leisure districts. ${ }^{21}$

Alongside these apocalyptic promises, northern editorialists offered landlords and proprietors relief from public reprisal if they could prove that the abuses of power exhibited by black waiters could be pinned on the "poor negro worshipper," Horace Greeley. In making the link between economic prosperity and the campaign for integrated leisure, editorialists reassured the northern public that the "abolitionists and shoddy contractors" who presided over the degradation of leisure by promoting the hubris of black domestic workers would soon find themselves in the "deluge" of 1865, when the summer season would be "far more delightful than that of $1864 . " 22$ However, by the end of the Civil War, neither the desired egalitarianism of 1861 and 1862 nor the promise of retribution and Jim Crow came to the leisure destinations of Saratoga, Sharon Springs, Niagara, or Newport. Although each of these resorts resumed their popularity after the Civil War, many of them were quickly outpaced by the developing beach communities of the New Jersey shore, where white business owners capitalized on both the fatigue of the war years and the progressive climate of the Reconstruction era to attract summer tourists and correct the racial and class flaws of more established summer destinations.

Throughout the 1870s and early 1880s, the social appeal of the Jersey shore and the revivalist sentiment of postwar American Methodism drew a diverse crowd of white and black travelers to Asbury Park, Atlantic City, Cape May, and Long Branch. Like

\footnotetext{
21 "The Reign of Terror and the Watering Places," New York Herald, June 6, 1863.

${ }^{22}$ Ibid.
} 
another popular creation of the American imagination, the "Wild West," the Jersey shore appealed to fatigued Victorians and striving white middle-class wage earners as a refuge from the physical and political congestion of the urban metropolis. ${ }^{23}$ Decorated with the latest modern marvels of postwar public amusements, the beach communities of the Jersey shore became an ideal setting for a war-weary nation eager to dissolve into a futuristic and pleasurable realm where time seemed to be suspended after decades of sectional conflict, political struggles over black civil rights, and unending labor strife.

Jersey shore beach towns such as Asbury Park and Atlantic City also benefited from the luxury of historical distance that freed them from the contentious racial and class stigmas that remained attached to resorts like Saratoga Springs. In 1861, much of the Monmouth County coastline that would become Asbury Park stood vacant, Atlantic City was still a distant dream of railroad agents, and the more popular destinations of Long Branch and Cape May failed to outpace in either attendance or social prestige the more established fashionable resorts of the era. In the 1870 s and $1880 \mathrm{~s}$, the creators of the Jersey shore were thus free to explore and create from barren beaches and untapped shorelines social visions of their own that blended the environmental with the cosmopolitan, the egalitarian with the hierarchical, and the revivalism with the consumerism.

Of the many architects and social visionaries that helped create the Jersey Shore, very few businessmen shared the relentless social vision of Asbury Park's founding father, James A. Bradley, a brush manufacturer from New York City who saw potential

\footnotetext{
${ }^{23}$ Marguerite S. Shaffer, See America First: Tourism and National Identity, 1880-1940, (Washington, D.C., 2001); John Walton, Histories of Tourism: Representation, Identity, and Conflict (New York, 2005).
} 
in the untapped land along the Monmouth county coast in the late $1860 \mathrm{~s} .{ }^{24}$ Seeking a spiritual and rehabilitative escape from his urban environment, James Bradley arrived in the small Methodist shore community of Ocean Grove in 1869 with his black servant, John A. Baker. After consulting with the town's Treasurer, David H. Brown, who pointed Bradley towards an unsettled section of land, Bradley and Baker proceeded to travel through a wilderness of shore brush that grew upon the uninhabited beaches. Reaching the water's edge and "desiring a bath," Bradley stripped off his clothes, and eagerly advised his reluctant companion to do the same and join him in the sand of the cool evening surf. A devout Methodist, Bradley explained that he found the cool waters of the Jersey surf to be "the best nervine for a man who is not absolutely past repair," and who "desires to break away from his calling or greed and camp out in the sea shore." After Baker eventually joined him by his side, Bradley recounted in a later local history of Asbury Park that he found the exercise reminiscent of "Robinson Crusoe by his man Friday" and persuaded others to enjoy the pleasures of integrated leisure. ${ }^{25}$

Bradley's local history of Asbury Park reflected the desire of northern businesses and tourist promoters to fashion a postwar resort industry that shielded tourists from the Civil Rights agitation and social disorder of Reconstruction. Concluding his personal story with the description of interracial bathing enabled Bradley and other white northerners to retain the humanitarian legacy of the Civil War while containing potential complaints from northern black tourists for greater access to leisure time and space. Bradley's local history also revealed the cultural strategies businesses and tourist promoters increasingly undertook to appeal to a greater variety of summer guests during

\footnotetext{
24 "Mr. Bradley of Asbury Park," New York Times, October 22, 1893.

${ }^{25}$ James A. Bradley, “A History of Asbury Park,” Asbury Park Journal, 1882.
} 
the $1880 \mathrm{~s}$ and $1890 \mathrm{~s}$. Unlike in the antebellum period when only wealthy summer travelers had free time or extra money for summer vacations, northern businessmen could no longer rely on the natural beauty and physical landscape of the seashore to sell itself to striving middle-class tourists eager to spend their leisure time in places that provided entertainment and social prestige. ${ }^{26}$

Reconstruction campaigns for leisure time by white middle-class and workingclass northerners transformed leisure communities and regional tourism into a highly commercialized and competitive enterprise that forced business leaders and boosters to resort to advertising and print culture to attract patrons. Taking their cues from the northern press and the era's national political parties, business owners and tourist boosters learned to appeal to a burgeoning mass audience, and through their resort narratives "exploit and harden them into virtual uniforms of identity." 27 The stories proprietors, boosters, and politicians told and sold in their promotional literature illuminate key aspects of northern culture and intellectual life for middle-class tourists and small business owners during the Gilded Age. Equally important, their stories reflect the class divisions many resort owners sought to close and the racial history they sought to forget. By seeking to attract a diverse pool of northern citizens through the allure of

\footnotetext{
${ }^{26}$ Thomas Chambers, Drinking the Waters: Creating an American Leisure Class at Nineteenth Century Mineral Springs (Washington, D.C., 2002); Richard Butsch, For Fun and Profit: The Transformation of Leisure into Consumption, (Philadelphia, 1990); Catherine Cooks: Doing the Town: The Rise of Urban Tourism in the United States, 1850-1915, (Berkeley, 2001); John Sterngrass, First Resorts: Pursuing Pleasure at Saratoga Springs, Newport, and Coney Island (Baltimore, 2001); Cindy Aron, Working at Play: A History of Vacations in the United States (New York, 1999); John F. Kasson, Amusing the Millions: Coney Island at the Turn of the Century (New York, 1978); Roy Rosenzweigh and Elizabeth Blackmar, The Park and Its People: A History of Central Park (Ithaca, 1992).

${ }^{27}$ For works that stress the impact of commercialization and consumption in postwar recreation and amusement, see, Alan Trachtenberg, The Incorporation of America: Culture and Society in the Gilded Age, (New York, 1982); T.J. Jackson Lears, Fables of Abundance: A Cultural History of Advertising in America, (New York, 1994); Richard Ohmann, Selling Culture: Magazines, Markets, and Class at the Turn of the Century (London, 1999); Lawrence Levine, High Brow/Low Brow: The Emergence of Cultural Hierarchy in America (Cambridge, 1988).
} 
both rehabilitative and commercial enticements, these businessmen crafted an array of historical narratives designed to sell as well as mediate the social performances they expected from summer travelers.

In designing and selling their resorts to prospective tourists, local boosters reached out to a variety of important print culture markets. Emerging shore towns like Asbury Park and Atlantic City printed multiple periodicals and pamphlets that sought to advise and council visitors on the cultural experience they were to expect and the social rules they were to follow while on vacation. Northern newspapers such as the New York Times, the Philadelphia Inquirer, the New York Herald, and the Baltimore Sun assisted the marketing strategies of the shore resorts by listing the region's elite citizens who spent their summer at the seashore. In addition, many marketing agents adopted promotional tactics initiated by many New England communities, who published local histories that announced a physical and social environment dedicated to overcoming the confusing social world and racial history of their own recent past. ${ }^{28}$ These Reconstruction-era retreats spoke of a racial past that was to be redeemed, while also insisting on a future in which social behavior, rather than race, would set the markers of citizenship rights in leisure spaces.

Atlantic City's proprietors narrated these visions in a variety of tourist literature disseminated to the northern public during the Reconstruction period. Unlike the traditionally elite communities of Saratoga Springs or Newport, Atlantic City's businesses and proprietors hoped to cater to a variety of white northern tourists during the summer months. Describing the South Jersey resort as the "City of Homes by the

\footnotetext{
${ }^{28}$ Joanne Pope Melish, Disowning Slavery: Gradual Emancipation and "Race" in New England, 17801860, (Ithaca, 1998); Dona Brown, Inventing New England: Regional Tourism in the Nineteenth Century (Washington, D.C., 1997).
} 
Seaside" in hopes of luring in the region's "better elements," the Camden and Railroad Annual Report of 1873 also boasted that the region hoped to convince aspiring "subordinates in their shirtsleeves" to enjoy the "quiet home-like atmosphere of the place. ${ }^{29}$ The success created by these marketing campaigns enabled Atlantic City to proclaim in 1885 that its resort town created the only community of its kind whose success depended "mainly to the unacknowledged distinctions of class in society." Its official guidebook boasted that in comparison to other rival communities, Atlantic City's residents, "the rich and the poor, the healthy and the invalid are equally well received." Indeed, "such a conglomeration of all classes," Atlantic City's proponents argued, "cannot be seen in any other seaside resort in the world. The rich banker does not look down upon the shop boy he meets," and with equal certainty, the literature proclaimed, "the boy thinks himself equally as good as the banker for he feels the few dollars in his pocket that he has been for so long scraping by" will prove him worthy of leisure time to his social superiors. ${ }^{30}$

In marketing the Jersey shore as a progressive and egalitarian retreat, businessmen and civic boosters benefited from a developing culture of commonality that gripped Gilded Age advice literature. Listing the "Don'ts of Hotel Life," the New York Recorder cautioned northern tourists, “don't think because you're important in your own town, you're somebody in a hotel." ${ }^{31}$ For first time visitors to the Jersey Shore, William Bishop instructed potential summer tourists that the Jersey Shore was "not a place to be

\footnotetext{
${ }^{29}$ Camden and Atlantic Railroad, Annual Report, 1873, 10.

30 "A Complete Guide to Atlantic City," (Philadelphia: Burk and McFetridge, 1885), 19. For local histories of Atlantic City, see, Charles E. Funnell, By the Beautiful Sea: The Rise and High Times of that Great American Resort, Atlantic City (New Brunswick, 1975); Martin Paulsson, The Social Anxieties of Progressive Reform: Atlantic City, 1854-1920 (New York, 1994); Bryant Simon, Boardwalk of Dreams: Atlantic City and the Fate of Urban America (New York, 2004).

${ }^{31}$ New York Recorder, July 26, 1891.
} 
permanent in. ${ }^{, 32}$ Indeed, throughout the Reconstruction period, many northern resorts fulfilled the egalitarian promises and common law tenants that cultural critics fought for during the early years of the Civil War. While Gilded Age literature promoted Horatio Alger rags-to-riches feats, advertising agents, litigators, and civic boosters simultaneously undermined those narratives by promoting a common law culture dedicated to the public's welfare over the profit motive of enterprising elites. Indeed, contrary to laissezfaire dogmas popularized by nineteenth-century contemporaries, the Gilded Age marketplace was never wholly surrendered to the impartial devices of an "invisible hand." In Supreme Court hearings and other legal treatises, leading legal scholars Jesse Root, Nathanial Chipman, and James Wilson justified the importance of preserving the social nature of man amidst the onslaught of industrialization and privatization. "It is not fit," James Wilson pronounced, "that man should be alone." ${ }^{\text {33 }}$ As social creatures bound by common identities with other travelers and consumers, Nathanial Chipman argued, "Man, sociable by the laws of his nature, has no right to pursue his own interest or happiness, to the exclusion of that of his fellow man. ${ }^{, 34}$ For legal theorists as well as northern captains of leisure, the "common" reaffirmed a recommitment to the "public" that many northerners believed was abandoned in the later years of the Jacksonian era by greedy landlords and scheming socialites. These commitments were reinstituted in a host of public amusements and leisure venues throughout the Gilded Age. Factory workers in Pittsburgh and Massachusetts enjoyed interacting with one another in saloons and

\footnotetext{
${ }^{32}$ Quoted in Sterngrass, First Resorts, 100.

${ }^{33}$ Quoted in Novak, The People's Welfare: Law and Regulation in Nineteenth Century America (Chapel Hill, 1996), 33

${ }^{34}$ Ibid., 41.
} 
baseball fields, while working-class women sought out social connection in dancing halls, dime novels, and street-corner boutiques. ${ }^{35}$

The architectural considerations of New Jersey's many beach towns reaffirmed these social priorities by stripping away the physical barriers that often divided classes of tourists at other northern vacation destinations. Businessmen and social engineers designed arcades, carousels, and restaurants with entrances that spilled out onto open-air boardwalks, leading tourists and summer bathers into endless stretches of sand and ocean waves. At Long Branch and Atlantic City, resort owners accommodated the voyeurism of beach life by building "swimming tanks" that provided hotel guests and paying customers with viewing rooms and "comfortable chairs" that allowed spectators to take in the latest summer fashions and amuse themselves with the daytime theatrics of bathers and flirtatious couples seeking relaxation, cheap thrills, and romance in the summer sun. ${ }^{36}$ Yet by the mid-1880s, white vacationers clashed with increasing numbers of black tourists and seasonal workers who appeared on the same beaches and boardwalks and in the same restaurants, bars, and dancing halls as whites, threatening with their presence to upset the idyllic fantasies of white tourists.

For a northern black laborer in the late nineteenth-century, few workplaces were as exciting as the beach towns of the Jersey shore. Throughout the Reconstruction era, popular beach resorts like Asbury Park and Atlantic City became summertime meccas for

\footnotetext{
${ }^{35}$ Francis Couvares, Remaking Pittsburgh: Class and Culture in an Industrializing City, 1877-1919 (Albany, 1984); Steven Reiss, Touching Base: Professional Baseball and American Culture in the Progressive Era (Lincoln, 1983); Roy Rosenzweig, Eight Hours For What We Will: Workers and Leisure In An Industrial City, 1870-1920 (Cambridge, 1983); Kathy Peiss, Cheap Amusements: Working Women and Leisure in Turn-of-the-Century New York (Philadelphia, 1986); Nan Enstad, Ladies of Labor, Girls of Adventure: Working Women, Popular Culture, and Labor Politics at the Turn of the Century (New York, 1999).

${ }^{36}$ New York Times, August 10, 1890.
} 
black college students and southern laborers who struggled to find lucrative employment opportunities elsewhere. Laboring often as dishwashers, cooks, hotel attendants, and in other service-oriented positions in Philadelphia, New York City, and Baltimore during the winter months, many blacks often left their posts for the summer to take up similar work in Atlantic City, Cape Map, and Asbury Park. Although the competition for these jobs left many to accept positions and wages beneath those they occupied back home, service work at the shore offered economic and social advancement beyond the opportunities available in many northern cities. ${ }^{37}$ Because ninety-five percent of all workers in Atlantic City were black, many African Americans were offered job opportunities as headwaiters, managers, desk clerks, and entertainers that accorded them middle- and upper-class status that would have been nearly impossible in other northern communities. On the other hand, black seasonal laborers who took work as busboys, dishwashers, or rolling-chair attendants faced harsh work schedules, degrading workplace encounters, and were often susceptible to economic downturns, bad weather, and dismal living conditions that affected their pay and leisure opportunities. As one local historian of Atlantic City has noted, for many seasonal laborers, working at the Jersey shore often meant "three months to hurry" and "nine months to worry.",38

These restrictions did not prevent many northern blacks from enjoying themselves. Black workers took advantage of the beaches during the day, and spent their evenings amusing themselves in impromptu dances and other social gatherings set up along the boardwalks and inside the bathing pavilions. Since these spaces did not charge

\footnotetext{
${ }^{37}$ The Colored American, August 25, 1900; "In the Merry Throng Down by the Sea," Philadelphia Inquirer, August 18, 1897.

${ }^{38}$ Richlyn F. Goddard, "Three Months to Hurry, Nine Months to Worry: Resort Life for African Americans in Atlantic City, 1854-1940" (PhD diss., Howard University, 2001); Nelson Johnson: The Northside: African Americans and the Creation of Atlantic City (Medford, NJ, 2010).
} 
admission, they quickly became a convenient and cheap recreational outlet for local black workers and a popular leisure destination for out of town black fraternal and church organizations that planned annual "jubilee" days. In contrast to local amusement venues in Philadelphia, New York City, and Baltimore, articles in the northern black press highlighted the Jersey shore's desirable summer conditions, tolerable Jim Crow standards, and growing commercial enticements for black men and women with time to spare and money to spend. Over time these and other middle-class black northerners established businesses for white and black tourists and operated black schools, churches, and fraternal organizations for members of the area's black Methodists. ${ }^{39}$

The desire of many African Americans to enjoy their leisure time in areas formerly reserved for whites threatened to undermine the meanings white tourists and businesses alike crafted for leisure space after the Civil War. Beginning in the 1880s, editorials in northern newspapers soon appeared with headlines proclaiming the dilemma of the "Negro by the Sea," increasing "Race Problems," and prompting many business owners and boosters to ask, "What are we going to do with our colored people?"40 Mindful that public racial tensions would be harmful to business, local officials and shore correspondents tried to calm the fears of white vacationers by reminding them of the marginalized space blacks occupied at the shore, as well as the important economic and cultural function they served in maintaining a service industry. A reporter from the

\footnotetext{
39 "West Side Story: Profile of a Black Community," Asbury Park Press, May 21, 1882. See also, Atlantic City Daily Union, Sept. 1, 1892; Atlantic City Press, Sept. 8, 1900; Federal Writers Project, Works Project Administration, "Earning a Living in Atlantic City," New Jersey Ethnic Survey, Box WK2, New Jersey State Library, 2. See also, Henry James Foster, "The Urban Experience of Blacks in Atlantic City, New Jersey: 1850-1915," (PhD diss., Rutgers, The State University of New Jersey, 1981); Daniel Wolff, $4^{\text {th }}$ of July, Asbury Park: A History of the Promised Land (New York, 2005); Mark S. Foster, " 'In the Face of Jim Crow': Prosperous Blacks and Vacations, Travel, and Outdoor Leisure, 1890-1945," Journal of Negro History, 84, (Spring, 1999).

${ }^{40}$ Philadelphia Inquirer, September 3, 1891; “Colored People Invade Atlantic,” Philadelphia Inquirer, September 2, 1897, 2.
} 
Atlantic City Daily Union declared, "He found no serious 'problem' agitating the public." Black workers were visible, but by and large they came, the reporter reassured "because they were needed and had been sent for as servants." In contrast to many urban tourist locations, in which the "servant problem" created animosities between guests and proprietors, Atlantic City's hired help, the Daily Union insisted, "kept in their place becomingly, and did not intrude to offend those who were over-sensitive as to race prejudice. ${ }^{, 41}$

Since Atlantic City businesses could not control the flow and behavior of black workers on area beaches and boardwalks, local officials lectured that some black presence was necessary to staff the jobs white workers wished to escape from during their summer excursions to the seashore. A shore reporter at Atlantic City declared that "the colored people" who make their living within the resort community "are natural born servants, taking bossing more meekly and gracefully, than white help, and are for these and other good reasons generally preferred." ${ }^{42}$ An article published in the New York Times on the role and personality of black waiters reiterated these sentiments. Reversing the wartime feelings that cast black workers as labor radicals, the article sought to educate whites on why "the negro waiters always say, 'Yes Sir."' Explaining that waiters in northern resorts were "the best colored waiters I have every seen," the article continued by noting, "they grin whenever they move, go about as softly as many kittens and speak even more quietly then they move.” Although black waiters remained "theatrical of course," those interviewed for the article acknowledged that such deferential "gesticulations" were important to "cultivate a degree and a kind of servility"

\footnotetext{
${ }^{41}$ Atlantic City Daily Union, August 1, 1893, 4.

${ }^{42}$ Ibid.
} 
that played up the artistic qualities whites were told to expect from black waiters. These cultural explanations allowed whites to promote a racially restrictive marketplace in which blacks' labor was at the service of white consumers. As another frequent visitor to popular northern leisure spots noted, "No Sir does not sound very well to a man, that's come to get whatever he wants. Whatever a gues' wants, the waiter must respond, 'Yes Sir'. That's what the guests are here for, and that's what the waiters must give 'em."43 The growing postwar desire to staff domestic service jobs with black men and women reflected a growing concern over labor and leisure in the Reconstruction period. In hotel journals, travel manuals, and etiquette guides, white northerners routinely debated the ideal worker for service employment. In the end, the demand from white tourists to be served only by blacks rather than white women compelled local businesses only to hire black domestic workers. Casting blacks as a dependent subaltern class was a key component of the postwar racial contract, and an integral part in racially marking occupations and access to consumer culture. ${ }^{44}$ Defining blacks as workers and minstrels was critical to a broader developing strategy of containment white business owners and local officials adopted in the face of white hostility to black leisure. This strategy allowed business owners to appease the two most important racial sensibilities of white tourists: that only whites were deserving of recreation and consumption and blacks were more than happy to serve. More importantly, these linguistic strategies enabled businessmen, local officials, and advertising agents to postpone the implementation of potentially disruptive segregation laws that often antagonized blacks and disrupted business.

\footnotetext{
43 "Many New Yorkers at Saratoga Springs," New York Times, August 1, 1902.

${ }^{44}$ Charles Mills, The Racial Contract, (Ithaca, 1997); Matthew Frye Jacobson, Barbarian Virtues: The United States Encounters Foreign Peoples at Home and Abroad, 1876-1917, (New York, 2001).
} 
Despite these assurances, many white tourists were not convinced that local officials were doing all they could to isolate blacks from the beaches and other public amusement venues. ${ }^{45}$ In the summer of 1885 , a vocal group of white visitors to James Bradley's resort called on Bradley and other local officials to remove blacks from Asbury Park's public sphere. In an attempt to purge the assembly of working class and "average" persons who mingled about freely after working hours, white guests in Asbury Park began calling for permanently enforced social and racial boundaries for their public sphere. In the town's Daily Journal on July 7, 1885, an editorial pointed out that the "average man is easily distinguishable," and insisted that the mass of "curiosities that have taken their position under the pavilion (white as well as black) be removed."46

For many white northern tourists, the Jersey shore's eclectic mix of wealthy guests, working-class laborers, middle class patrons, and black tourists and domestic workers, made the shore's social landscape into a melting pot of cultural and political conflicts rather than a place of leisure. To solve the problem, a follow- up article appeared in the Daily Journal ten days later narrowing the list of objections to the black workers and tourists of Asbury Park, who, according to the complaint, "hang, intruding themselves in places designed only for guests, monopolizing the promenade, pavilion, and seats, and not content with that they come on excursions by the train load, and some days the whole beach is given up to them." ${ }^{47}$ The cultural and economic liability posed by the presence of black tourists and domestic workers revealed the fragile nature of racial identity for many ordinary white northerners after the Civil War. Throughout the

\footnotetext{
${ }^{45}$ Philadelphia Inquirer, August 7, 1885.

46 "Impudents," The Daily Journal, July 7, 1885; "Two Distinct Factions," The Shore Press, October 22, 1885.

47 “Too Many Colored People," The Daily Journal, July 17, 1885; “Their Jubilee Day,” New York Times, July 21, 1887.
} 
Reconstruction period, white northern citizens found themselves renegotiating racial hierarchies in a variety of new daily encounters, while politicians and litigators worked to solidify old social and racial categories upset from emancipation and postwar Civil Rights debates. ${ }^{48}$ The inability of Reconstruction-era politics to effectively solve these disputes led to a variety of uncomfortable social encounters and political protests throughout the North's amusement and consumption districts.

To many white northerners, the increased racial tension was not isolated to Asbury Park, but could also be seen spilling over into smaller recreational destinations in the area. In Gloucester City, New Jersey, a small beach resort that dubbed itself the "The Poor Man's Cape May," residents used a similar coded vocabulary to isolate blacks, blaming "sporting" and "rough behavior" on black excursionists who frequented area taverns. ${ }^{49}$ At Lakeside Park, whites singled out unruly black excursions and entertainment as justification for segregated leisure. Throughout the Reconstruction period, black organizations from Philadelphia frequently leased out days at Lakeside Park for white and black working-class men and women who could not afford extended vacations to Atlantic City or Cape May. A frequent form of entertainment at these excursions was the presence of marching bands that paraded behind excursionists in their way in and out of Lakeside Park. On June 26, 1885, however, Leon Davis, the bandleader of the West End Colored Fife and Drum Corp led his unit beyond the confines of Lakeside Park. Followed by a "hooting and yelling mob of several hundred people, of all ages and colors," Davis was arrested and black excursionists came under increased attack

\footnotetext{
${ }^{48}$ Masur, "A Rare Phenomenon of Philological Vegetation"; Fahs, The Imagined Civil War.

${ }^{49}$ Philadelphia Public Ledger, July 12, 1876; West Jersey Press, July 2, 1879; Philadelphia Public Ledger, August 8, 1876; See also, Brian E. Allnut, "The Negro Excursions: Recreational Outings among Philadelphia African Americans, 1876-1926," Pennsylvania Magazine of History and Biography, 129 (January, 2005): 73-104.
} 
for betraying the decorum of leisure spaces and inciting social disorder by "creating a nuisance on the street. ${ }^{, 50}$

The racial incidents at Asbury Park, Gloucester City, and Lakeside Park exposed broader political tensions over the meaning of the public in postwar leisure spaces. As many whites claimed, the everyday sociability of the workday public was a much different social space than the pleasure-seeking settings of the Jersey shore. The workday public reaffirmed a society committed to free labor ideology, in which common artisans, mechanics, clerks, and factory workers met as equals, each laboring in a burgeoning democratic society dedicated to the promise of social mobility. Although this everyday public witnessed heated political debates concerning job discrimination, interracial contact seemed less likely to overturn the nation's political economy. In contrast, the interracial public of beaches, boardwalks, and amusements parks elicited fears of social equality and consumer rights that threatened to radicalize critical components of Gilded Age America's economic and social foundations.

Throughout the late 1880s, white tourists increasingly pressured tourism promoters and business owners to market their sites as segregated leisure destinations. To do so, several northern whites sought to downplay the emancipationist narrative constructed by Radical Republicans and Black political leaders elsewhere in the 1860s and 1870s. Writing in the Daily Journal, one patron of Asbury Park lectured the town's local officials and northern blacks that the effort to provide political and legal aid to African Americans during Reconstruction was a paternal and "generous aid" provided by the "Christian spirit of right-minded white men." The Constitutional amendments which followed Emancipation and the Civil Rights Act extended by the Republican Congress

\footnotetext{
${ }^{50}$ Philadelphia Inquirer, June 26, 1885.
} 
were soon replaced, the individual explained, by the ungrateful attitude of African Americans who clamored for social equality. ${ }^{51}$

Although many scholars have addressed the multiple ways that Civil War memory was created and contested through monuments, parades, pageants, and southern plantation tours, white middle-class tourists who took to the boardwalks and beaches of resort communities and the editorial pages of the northern press created their own narratives of emancipation in the postwar period. Indeed, the recent inclination of scholars to place emphasis on northerners' southern tourism as a cultural marker of national reunion has obscured the postwar realities of leisure and the distinct regional interests and political meanings that white middle-class tourists placed on leisure time and space in the post-Reconstruction period. ${ }^{52}$ Most northern citizens lacked both the time and money for extended southern trips. Leisure time was precious and often included weekend getaways to the seashore, rather than lengthy vacations to southern tourist sites. Working-class whites that visited the Jersey shore offered their own views on the legacy of Reconstruction that had less to do with reuniting with the South than they did with protecting their privileged access to leisure marketplaces through the execution of segregation laws. Instead, those who visited the Jersey Shore sought to create rules for public leisure spaces by clinging to pre-war notions of racial and class separation that rejected the justifications of proprietors as well as black claims for integrated leisure. Uncomfortable with the way in which the postwar political and social climate had diverged into a program for black Civil Rights, many white tourists who

\footnotetext{
51 “The Offenders," The Daily Journal, June 29, 1887.

${ }^{52}$ Nina Silber, Romance of Reunion: Northerners and the South, 1865-1900, (Chapel Hill, 1997); Shaffer, See America First.
} 
visited the seashore reminisced fondly of a time when racial tension had been muted by slavery and more oppressive forms of class subordination. ${ }^{53}$

In seeking to strip the towns of Asbury Park and Atlantic City of their former spiritual and rehabilitative identity, summer guests pressured the proprietors and town councils of the Jersey shore to create segregation laws that mirrored their own northern neighborhoods, while re-writing the history of the Civil War and Reconstruction to justify the policies. As whites in Asbury Park explained to business owners and local officials, "There were those among the colored race," who were not satisfied with what had already been done, but wanted more. It was not enough to possess all the rights and privileges as white citizens, but those rights must be insolently demanded." To black activists they explained, "respect and equality can never be gained." Instead, they argued that only through passive acceptance of the current social standing could the cultural stereotypes accompanying black grievances be eliminated. ${ }^{54}$ These competing historical narratives between white business owners and white tourists reveal the public relations dilemma marketing agents faced in promoting beach resorts in a postemancipation age of mass consumption.

Marketing agents and northern journalists responded to the complaints from white tourists by downplaying the racial tension to a few agitators and by highlighting the racial progress they witnessed at popular beach resorts. A reporter for the Philadelphia Times

\footnotetext{
${ }^{53}$ For a sample of the large body of scholarship on race and memory during the Reconstruction period, see David Blight, Race and Reunion: The Civil War in American Memory (Cambridge, 2001); W. Fitzhugh Brundage, The Southern Past: A Clash of Race and Memory (Cambridge, 2005); Andrew Kahrl, "The Political Work of Leisure: Class, Recreation, and African American Commemoration at Harpers Ferry, West Virginia, 1881-1931," Journal of Social History 42 (2008): 57-77; Kirk Savage, Standing Soldiers, Kneeling Slaves: Race, War, and Monument in Nineteenth Century America (Princeton, 1997); Leslie Schwalm, Emancipation's Diaspora: Race and Reconstruction in the Upper Midwest (Chapel Hill, 2009); Nina Silber, The Romance of Reunion: Northerners and the South, 1865-1900 (Chapel Hill, 1997).

${ }^{54}$ The Daily Journal, June 29, 1887.
} 
observed that on the famed Atlantic City boardwalk that "all nations and races" mingled freely during the bathing hours without the slightest hint of Jim Crow tensions. "Sit on the beach for an hour and you see the widest diversity of human types" the Times declared. "The Saleswoman brushes her best all-wool against the silk of the millionaires wife, and the millionaire" is forced to interact with the "waiter who just handed him his bill of faire. ${ }^{, 56}$ A correspondent dispatched to Long Branch observed similar sights and sounds. "Up and down the beach," the reporter observed that "bathers of all sizes" mingled "happily in the water without reference to age, sex, or previous condition of servitude., 57

To these white observers, the integrated atmosphere of the Jersey shore seemed to reaffirm broader changes in northern race relations after the Civil War. The editor of the Atlantic City Review explained, "While the colored people have never attempted to secure accommodations at a hotel, they have in perhaps all cases been supplied with refreshments at the bar. ${ }^{, 58}$ Covering the racial tension in Asbury Park, the New York Times similarly observed that the region's leisure destinations witnessed "greater social mobility than at Long Branch or at any other place along the coast.. ${ }^{, 59}$ When these observations were not enough to appease blacks that insisted on unregulated access to public amusements, white citizens occasionally called on Bradley to erect public spaces and establishments that would cater solely to the interests of its black residents. Criticizing the "colored invasion" of its space, one objector in the Daily Journal asked

\footnotetext{
55 "The Negro by the Sea," Philadelphia Times, July 25, 1890.

${ }^{56}$ Philadelphia Times, July 20, 1890.

${ }^{57}$ New York Times, August 23, 1885, 3.

${ }^{58}$ Atlantic City Review, August 21, 1884, 1.

59 “The Colored Controversy,” New York Times, July 21, 1885.
} 
whether "Mr. Bradley could be persuaded to build a pavilion for their use and locate it in the immediate neighborhood." 60

To defuse the racial tension, white business owners and local political figures sought a variety of temporary compromises. In Asbury Park, local officials instituted clock-time segregation by temporarily yielding the boardwalks and beaches to workingclass blacks after regular business hours. As the Philadelphia Inquirer explained, “Everybody turns out upon the promenade after 6 o'clock, and fill the pavilions and all the seats and gaze upon the majority." This "keeps in motion" the paper noted "until 10 and 10:30, when the colored population turns out, as if at a pre-concerted signal, and swarms over the boardwalk." ${ }^{61}$ Uncomfortable with allowing African Americans free rein over its public sphere after dark, Atlantic City and Lakeside Park dividing up the summer vacation season, reserving the months of August and September for African American vacationers, a form of seasonal segregation, which served as an intermediate move between integration and full segregation. In doing so, northern whites believed they could appease both constituents. White tourists could enjoy summer outings during the prime summer months without having to interact with seasonal laborers or black tourists, and African Americans would be granted unrestricted access to leisure accommodations during the latter part of the summer when other working-class tourists usually took their vacations. ${ }^{62}$ To market the proposal to African Americans, the northern press touted the measure as the extension of a working-class holiday season to blacks, rather than a Jim

\footnotetext{
60 "Colored Invasion," Daily Journal, August 5, 1886.

${ }^{61}$ New York Times, October 22, 1893; “Asbury Park: Why People Are Living in Hotels Rather than Cottages," New York Times, July 13, 1890. The Times noted that "For years the question, "What to do about the colored people," has been a vexed one. Their presence on the beach in large numbers was last year for a time offensive... This trouble was overcome by appointing certain hours, late in the evening, for their pleasure along the beach walks. This year, the same difficulty will be met in the same way."

${ }^{62}$ Camden County Courier, June 5, 1880; Camden County Courier, July 28, 1883; West Jersey Press, August 20, 1884.
} 
Crow policy aimed to shield black protests. When African Americans criticized the measure during the 1890 summer season, the Philadelphia Times explained that blacks were not the only ones restricted to the late summer months. "The last two weeks of August," the Times instructed, was also the "popular holiday time for the great company of Philadelphia store girls, and for the respectable working-classes generally." ${ }^{63}$

Highlighting the late summer excursions of other marginalized working-class groups allowed segregationists to offer a Jim Crow justification based on class difference rather than race prejudice, forestalling more permanent solutions to the escalating problem. During the summer of 1887 , Bradley appointed a beach superintendent to enforce "modest bathing suits," which allowed law enforcement, as one local observer noted to "prevent the colored people from monopolizing the beach to the exclusion of visiting white people., ${ }^{\prime 64}$ However, Bradley's ad-hoc approach to segregation allowed blacks to consistently ignore his "polite requests" and informal policing tactics. In the years that followed many black workers and tourists continued to refuse the requests to enjoy their leisure elsewhere or restrict their excursions to August and September. Unable to prevent blacks from holding all-night parties, James Bradley relocated the black population to facilities set up exclusively for their own recreation. In the months leading up to the 1889 summer season, Bradley commissioned the construction of three Jim Crow bathing facilities set apart from those used by whites. However, that summer, tensions once again arose as many blacks ignored the requests to stay off the beaches and boardwalks during the day, and continued to use the old bathing pavilions. The New York Times explained in June 1889 that despite requests to keep away from whites during

\footnotetext{
${ }^{63}$ Philadelphia Times, August 16, 1890.

${ }^{64}$ Camden Courier, June 25, 1887.
} 
prime bathing hours, the "teeming negro settlements in West Asbury Park shows no decrease. ${ }^{95}$ In response, Bradley posted an official notice asking area blacks to again "please refrain from using the beach during the fashionable hours of the day.",66

To defend the new Jim Crow statutes, business owners and the northern press compared the irrationality of black behavior to the traditionally liberal attitude many white business owners exhibited toward black leisure. A defender of Bradley's notices explained to the northern press that ordinances were adopted as a reaction to the "swarthy African" who has become "bolder year by year." Documenting the preference of whites to police the color line through informal measures, the town's segregationist defenders insisted that bolder plans were initiated only after "the other side responded with mass meetings," and "zealous pastors" called on area blacks to "maintain their rights at any cost." In its coverage of the escalating racial tension, the New York Times declared that Bradley consistently expressed his public support for the town's black community by explaining that his request was in the best interest of all black workers who wished to retain summer employment in a profitable service industry. ${ }^{67}$

In 1890, Bradley's gradual approach to enforcing segregation introduced new problems when whites attempted to use the Jim Crow beach facilities during hours reserved for blacks. The Asbury Park Press noted on July 19, 1890 that "now whites have to be watched to keep from trespassing on the colored people" since "white people do not seem to understand" that the cordoned off area at Second Avenue is "not for their use, and the authorities are having a considerable trouble in causing the rule to be

\footnotetext{
65 "The Color Line at Asbury Park: Visitors Annoyed at Colored Servants on the Beach," New York Times, June 30, 1889.

66 "Colored People Indignant: Likely to Place Obstacles in Founder Bradley's Way," New York Times, July 20, 1893.

${ }^{67}$ New York Times, June 30, 1889.
} 
understood. ${ }^{968}$ Before the start of the 1893 summer season, Bradley moved to officially restrict all African Americans, both those who worked as well as those who sought to vacation in Asbury Park, from the beaches and other shore facilities. Posting signs throughout the community and stationing officers at pertinent shore locations, Bradley prohibited all black citizens from entering the beaches, bathing houses, pavilions, and promenades. ${ }^{69}$

Reluctant to embrace Jim Crow for the same reasons that many white tourists did, Bradley and local business owners instead carefully crafted segregation notices and adopted gradual social boundaries to avoid interruptions to business. To separate themselves from the mass of white racists, they used phrases like "Please refrain" and "We ask that you" in their public notices. As these decisions indicate, the postReconstruction period required new methods of marketing and enforcing segregation from those deployed before the Civil War. In particular, the sporadic and impromptu strategies that segregationists developed reflected the instability of racial imagery to peacefully police the public sphere. Yet, business owners and local officials struggled to define what message and tactic would replace older strategies, consistently failing to manage the pubic behavior of black consumer activists or the public sentiments of white tourists through informal requests and ad-hoc policing tactics. Realizing the failure of their approach, segregationists implemented a new Jim Crow strategy throughout the 1890s to sustain segregation at the Jersey shore, one built around reconfigured ideas about the common law and political economy. How business owners, white tourists, and

\footnotetext{
68 "The Tables Are Turned," Asbury Park Press, July 19, 1890.

69 "Bradley Statement," Shore Press, July 8, 1887.
} 
black workers came to view these early battles would shape the future implementation and contestation of segregation at the Jersey Shore in the years ahead. 


\section{Chapter 2: Occupying Jim Crow, 1885-1893}

On the night of June 28, 1889, William Nelson, a black employee of an ice cream parlor, stood watching a carousel ride inside the Palace, an indoor amusement arcade located on the boardwalk of Asbury Park. When a white security guard attempted to remove him from the facility, Nelson fought back, prompting a fist fight with the officer, John A. Krause, outside of the Palace premises. After both men were arrested and fined for the incident, the Palace owner Ernie Schnitzler responded by restricting entrance into the pavilion to season ticket holders, which, according to an account published in the town's Shore Press, were sold and distributed only to the Palace's white patrons. However, after immediate public protests from black demonstrators, Schnitzler reversed his decision and allowed black citizens back into the Palace. ${ }^{1}$ Concluding its coverage of the altercation a few days later, the Shore Press predicted, "It is probable that no future trouble will result."2

The decision by Ernie Schnitzler to readmit black customers and the desire of Asbury Park's local officials to downplay the incident did not put an end to segregation, and it did not limit civil rights protests from local blacks. Violence erupted again four years later when black waiters at the Plaza Hotel refused to honor recently instituted segregation ordinances restricting them from accessing the dinning rooms and bars of Asbury Park's hotels. After four black waiters completed their shift on the night of August 4, 1893, they attempted to access the hotel bar before the hotel's manager John H. Quinn stopped them. When the four men refused Quinn's request to vacate the area, Quinn attempted to remove one of the waiters by force, but not before the other three

\footnotetext{
1 "Defining the Color Line," Asbury Park Press, June 27, 1889.

2 "Palace Guard Incident," Shore Press, June 28, 1889.
} 
jumped him, initiating a full-scale brawl on the barroom floor. The next day, the hotel proprietors ejected all black members of the wait staff and replaced them with white men and women. Refusing to leave their posts when the white replacements arrived, area police were finally dispatched and arrested the remaining black workers. In the days that followed, racial tension pervaded the town as white guests and area blacks waited for a final resolution. Despite threats announcing "another round of race riots," the Plaza Hotel finally readmitted the black workers to their posts the following week. ${ }^{3}$

The violent public encounters between blacks and whites in Asbury Park demonstrate the serious lengths northern blacks pursued to ensure admission to leisure space, as well as the victories they could achieve through collective consumer activism. Throughout the 1880s and early 1890s, African Americans saw the region's emerging Jim Crow social relations as part of a disturbing nationwide trend toward racially defined public and commercial boundaries. In their collective decision to demand integrated leisure, local black workers put the region's leaders on notice that antebellum era strategies of resistance and accommodation would no longer be pursued. During the antebellum period, many northern black intellectuals and Civil Rights leaders believed that African Americans should devote their leisure hours to self-improvement rather than consumption and entertainment. ${ }^{4}$ Yet after the Civil War, northern black workers and tourists argued that until they were provided equal access to leisure venues, broader claims to social progress and racial equality would be incomplete. In asserting their claims to leisure space as the fulfillment of their citizenship rights, black consumer

\footnotetext{
3 "Riots Feared at Asbury Park: Colored Waiters Will Resist Their Supplanting by Whites," The Evening World, August 4, 1893.

${ }^{4}$ Leslie Harris, In the Shadow of Slavery: African Americans in New York City, 1626-1863 (Chicago, 2003); Joanne Pope Melish, Disowning Slavery: Gradual Emancipation and "Race” in New England, 1780-1860 (Ithaca, 1998).
} 
activists not only reframed the postwar debate for white citizens, but also signaled an end to a time when only black political leaders and intellectuals set the political agenda for their race. ${ }^{5}$

African Americans' civil rights claims to integrated public accommodations also signaled the divided political power of white supremacy in leisure spaces. While journalists, cartoonists, and tourists helped popularize white supremacist imagery, black workers, reformers, and tourists regularly manipulated class divisions among whites and fought against discrimination by claiming full rights as citizens, access to public space, and free choice as consumers. Black workers and tourists at the Jersey shore believed that to overturn northern segregation laws, African Americans needed not only to challenge the traditional political and legal barriers that limited black mobility and consumption, but also to confront white northerners in public and in print by disputing and disrupting the cultural hierarchies of race that often defined Jim Crow boundaries.

The intellectual history of Jim Crow at the Jersey Shore demonstrates the efforts of northern black tourists and workers to reestablish authority over the historical construction of race that whites fought to reconfigure throughout the postwar period. In recent years, historians have captured the myriad ways whites used understandings about ethnicity, political economy, and sensory imagery to reconfigure racial meanings. ${ }^{6}$

\footnotetext{
${ }^{5}$ The claims by working-class blacks to spend their leisure time at public amusements initiated a lengthy and contentious conversation within the black community. See, Willard Gatewood, Aristocrats of Color: The Black Elite, 1880-1920 (Fayetteville, 2000); Jacqueline Moore, Leading the Race: The Transformation of the Black Elite in the Nation's Capital, 1880-1920 (Charlottesville, 1999); Michele Mitchell, Righteous Propagation: African Americans and the Politics of Racial Destiny after Reconstruction (Chapel Hill, 2004); Andrew W. Kahrl, “ 'The Slightest Semblance of Unruliness': Steamboat Excursions, Pleasure Resorts, and the Emergence of Segregation Culture on the Potomac River," Journal of American History, 94.4 (March, 2008):1108-1136.

${ }^{6}$ Mark Smith, How Race Is Made: Slavery, Segregation, and the Senses (Chapel Hill, 2006); I.A. Newby, Jim Crow's Defense: Anti-Negro Thought in America, 1900-1930 (Baton Rouge, 1965); Orlando Patterson, The Ordeal of Integration: Progress and Resentment in America's Racial Crisis, (New York, 1997);
} 
However, the ways in which black protestors resisted white racial constructions and subverted the various discursive, legal, and political barriers of segregation has received only cursory attention. Indeed, while we know much more about black civil rights efforts during the Civil War and Reconstruction, as well as the formation of black political organizations at the turn of the century, there remains a sizable gap in the secondary literature concerning the civil rights successes northern blacks achieved throughout the final two decades of the nineteenth century. ${ }^{7}$ The claims by African Americans for integrated leisure at the Jersey shore invites new ways to approach how black workers and tourists navigated and undermined the dominant racial language deployed by northern politicians, businessmen, and ordinary white citizens after Reconstruction. In a service economy that demanded a silent and subservient working class, the routine deployment of written challenges by black workers and community leaders helped to counter the emerging Jim Crow laws and justifications along the Jersey Shore in the years before Plessy.

Matthew Pratt Guterl, The Color of Race in America, 1900-1940, (Cambridge, 2001); Thomas Guglielmo, White on Arrival: Italians, Race, Color, and Power in Chicago: 1890-1945 (New York, 2003); David Roediger, The Wages of Whiteness: Race and the Making of the American Working-Class (New York: Verso, 1991); Nikhil Pal Singh, Black Is a Country (Cambridge, 2004); Eduard Bonilla-Silva, Racism Without Racists: Color-Blind Racism and the Persistence of Racial Inequality in the United States, (Lanham, 2003).

${ }^{7}$ Blair Kelley's Right to Ride is one of few works that addresses the Gilded Age civil rights campaigns of northern black activists and consumers. Blair Kelley, Right to Ride: Streetcar Boycotts and African American Citizenship in the Era of Plessy vs. Ferguson (Chapel Hill, 2010). By and large, though, southern scholars have done a much better job exploring the Civil Rights achievements between the end of Reconstruction and the formal declaration of Jim Crow in 1896. See, Jane Dailey, Before Jim Crow: The Politics of Race in Postemancipation Virginia (Chapel Hill, 2000); Glenda Gilmore, Gender and Jim Crow: Women and the Politics of White Supremacy in North Carolina, 1896-1920 (Chapel Hill, 1996); and Leslie Schwalm, Emancipation's Diaspora: Race and Reconstruction in the Upper Midwest (Chapel Hill, 2009). For an excellent treatment on the ways in which African Americans negotiated leisure space and historical memory in the postwar border South, see, Andrew W. Kahrl, "The Political Work of Leisure: Class, Recreation, and African American Commemoration at Harpers Ferry, West Virginia, 1881-1931," Journal of Social History 42 (2008): 57-77. 
Denied entry to public leisure spaces, blacks responded by evoking the common law tradition and their rights as consumers. In a series of public acts northern black patrons were readmitted to beaches, dancing halls, and amusement venues by arguing that leisure venues were not private space, but were instead critical components of the public sphere that sustained a free market society. Thus, when whites justified new segregation laws as a defense of private property, blacks countered that an overregulated marketplace was restricting their consumer rights in an effort to mask unpopular racial animosities. As many blacks argued, the political power of Jim Crow often rested on the ability of whites to narrow the definition of a free labor society. Many white segregationists maintained that the degradation of property under the guise of consumer rights would corrupt the free market system, allowing a host of disreputable and illegitimate political actors to operate uninhibited. Black workers, on the other hand, argued that the right to consume was equal to the right to work; that the dignity one received from work was as important as the respectability one attained from leisure. By couching their arguments within the same political vocabulary used to win the right to vote and to integrate public transit systems, black protesters gradually regained access to beaches, boardwalks, and other entertainment venues that attempted to exclude them throughout the late 1880 s and early 1890s.

In the late-nineteenth century, local black fraternal and religious organizations took the lead in promoting black recreation in segregated beach resorts. When the issue of leisure and consumption was largely ignored by leading black activists and race experts and given secondary priority by national black organizations, it was left up to 
local civic leaders and ordinary black workers and consumers to shape the strategies and tactics for defeating Jim Crow at northern beach resorts. When whites began to stigmatize, confine, and punish black leisure activities at the Jersey shore in the mid1880s, local black activists used their leisure hours to formulate oppositional tactics and strike against the intrusive boundaries of segregationist defenders. Guided by the political and religious leadership of the African Methodist Episcopal Church (AME), civil rights organizers in Asbury Park and Atlantic City helped lead regular rallies, demonstrations, and public meetings denouncing the discursive attacks on black leisure habits and their culturally assigned place within the public sphere. ${ }^{8}$

The proactive strategies and tactics initiated by local blacks in these popular shore towns signaled a significant shift in the political philosophy of leisure and civil rights in the postwar North. Antebellum era religious organizations and race leaders were often hesitant to embrace popular amusement venues as an appropriate leisure outlet for middling blacks. To many antebellum black leaders, northern amusement settings were lawless sites that led to economic ruin for working-class blacks and social discrimination for the race's "better elements." Honoring the antebellum era's republican ethos, northern Civil Rights leaders and leading black intellectuals admonished northern black laborers to vacate the region's urban amusement districts and instead replicate the respectable leisure habits of black aristocrats. ${ }^{9}$

\footnotetext{
8 "Defending Their Race," New York Times, July 20, 1885; “Color Line at Asbury Park: Negroes Indignant at Threatened Exclusion from the Beach," New York Times, June 25, 1887; and The Shore Press, "250 People," July 1, 1887.

${ }^{9}$ Gatewood, Black Aristocrats; Harris, In the Shadow of Slavery; Melish, Disowning Slavery, 279; and Elizabeth Raul Bethel, The Roots of African American Identity: Memory and History in Free Antebellum Communities (New York, 1997), 55; Leon Litwack, North of Slavery: The Negro in the Free States, 17901860 (Chicago: University of Chicago Press, 1961); James Oliver Horton, Free People of Color: Inside the African American Community (Washingtonn, D.C., 1993); Patrick Rael, African-American Activism Before the Civil War: The Freedom Struggle in the Antebellum North, (New York, 2008); Phyllis F. Field, The
} 
After the Civil War, however, many working-class blacks argued that these narrow political objectives ignored the broader implications of segregation. Overtime, black religious and fraternal organizations also came to embrace claims for integrated public amusement venues. As pastors witnessed new generations of blacks denied access to public accommodations, popular amusements became the latest visible reminder of Jim Crow's ascent during the nineteenth century. To fight for integrated leisure and reclaim public accommodations as a political right due to all citizens, civil rights leaders often reconfigured the political functions of religious institutions. Before the Civil War, many religious organizations served as fraternal lodges where middle- and upper-class blacks could sharpen their rhetorical and performative skills. After 1865, however, many organizations shifted their organizational priorities and became grassroots legal and political venues that aimed to promote and refine the political skills of all blacks so that they could collectively fight the cultural authority and political power of Jim Crow. ${ }^{10}$ Religious institutions served an important function in civil rights debates at the Jersey shore because they were often the black community's most visible and vocal moral arbiter, publicly discrediting the immoral logic of Jim Crow in churches, streetcorners, and area beaches. Objecting to the ways in which many northern white tourists linked the public presence of black residents to indecent social behavior, northern black citizens and civic leaders reminded northern proprietors and tourists about the common

Politics of Race in New York: The Struggle for Black Suffrage in the Civil War Era (Ithaca, 1982); Julie Winch, Philadelphia's Black Elite: Activism, Accommodation, and the Struggle for Autonomy, 1787-1848 (Philadelphia, 1988); Gary B. Nash, Forging Freedom: The Formation of Philadelphia's Black Community, 1720-1840 (Cambridge, 1988); John Ernest, Liberation Historiography: African American Writers and the Challenge of History, 1794-1861 (Chapel Hill, 2004).

${ }^{10}$ Stephen Kantrowitz, "Intended for the Better Government of Man: The Political History of African American Freemasonry in the Era of Emancipation," Journal of American History 96.4 (March, 2010): 1001-1026; John Ernest, A Nation Within a Nation: Organizing African-American Communities Before the Civil War (Chicago, 2011). 
law's oath to uphold the moral responsibility of public venues to allow unregulated access. At a large meeting held at the A.M.E. Church of West Asbury Park in the summer of 1887, Reverend J. Francis Robinson called on his congregation to attack "all class legislation and race distinction where the statutes of citizenship and of good behavior introduce the common right." Robinson declared that the "man who advocates the separation of whites and blacks from the equal enjoyment of civil prerogatives solely on the grounds of color places himself in a position to be questioned as to his patriotic proclivities and the genuineness of a Republic form of government." ${ }^{, 11}$ Reverend A.J. Chambers, Pastor of the Bethel Methodist Church in Asbury Park, denounced the editorial staff of the town's Daily Journal for promoting policies that were "uncalled for, unwarranted, unchristianlike, and cruel. ${ }^{.12}$

Reflecting on the "color question" and the idea of moral responsibility, Reverend J.H. Morgan also asked whether the moral and civic lapses by a few people of a given class could be held against an entire race. Morgan commented that,

It does seem strange that so many of our friends on the other side do not seem able to distinguish any difference between colored people as regards to moral, religion or the right of manhood; and those of them who admit it seem to view it in the same light as the boy who visited the country fair and saw a cow that looked for all the world like his father's cow. You could not tell them apart, only one was white and [the] other black. 'All colored people are alike' seems to be the maxim (especially if there is finance to be considered) either by action against us or indifference for us. ${ }^{13}$

To counter prevailing Jim Crow sentiments, many black political leaders called on segregationists to enforce social boundaries on the basis of conduct and inquired about

\footnotetext{
11 "Answering Mr. Bradley: Colored People at Asbury Park Speak Out In Meeting," New York Times, June 28, 1887.

12 "Drawing the Color Line at Asbury Park: Negroes Who Offend the Residents of Asbury Park," New York Times, July 19, 1885.

13 “Asbury Park Colored Question," The Christian Recorder, Aug. 3, 1893.
} 
why white people did not object to the presence of black servants serving their meals and handling their laundry. ${ }^{14}$ As G.W. Johnson, a waiter in Asbury Park's Sheldon House, instructed, "If a white man acts boisterous, rude, or ungentlemanly, he is arrested and/or fined." Yet, Johnson attested, "the white people as a class are not blamed for the actions of one man." ${ }^{15}$ A black protestor who penned an editorial in The Sun, echoed Johnson's sentiments. "It seems that the white visitors, even when they are fellow Methodists," the man exclaimed, "are not averse to employing them as servants," but "are outraged when they find the privileges of the beach largely enjoyed by the colored visitors."16

To defend their claim to public leisure spaces, African Americans used the northern press to provide proof that such claims could be substantiated from actual encounters and experiences. In promoting black lawlessness and stigmatizing the “degraded" and "criminal" nature of black leisure, white segregationists pointed to “impartial” empirical evidence to justify racial policies. ${ }^{17}$ In contrast, many black leaders made it a point to catalogue and report instances of orderly black behavior. A frequent visitor to Asbury Park recalled that the majority of black tourists and workers are "very fine-looking men and women, and generally they are remarkable for the dignity of their behavior." Indeed, most blacks displayed, he noted, "more taste than the run of white

\footnotetext{
14 “A.J. Chambers and 'The Journal'," The Christian Recorder, Aug. 6, 1885; NYT, “Answering Mr. Bradley."

15 "From a Colored Man's View," Daily Journal, July 21, 1885.

16 "The Color Line at Asbury Park," The Sun, June 29, 1887.

${ }^{17}$ Khalil Gibran Muhammad, The Condemnation of Blackness: Race, Crime, and the Making of Modern Urban America (Cambridge, 2010); William H. Tucker, The Science and Politics of Racial Research (Chicago, 1994); Kali N. Gross, Colored Amazons: Crime, Violence, and the Black Women in the City of Brotherly Love, 1880-1910 (Durham, 2006). Northern efforts to explain away white racism date back to the late-nineteenth century when a new generation of race experts argued in favor of a color-blind approach to explaining the "plight of the negro." See, Frederick L. Hoffman, Race Traits and Tendencies of the American Negro, (New York, 1896); Nathan S. Shaler, "The Negro Problem," Atlantic Monthly 54 (1884): 696-709; Science and the African Problem, Atlantic Monthly 66 (July 1890); The Nature of the Negro," The Arena, December 1890, 23-35; Francis A. Walker, The Colored Race in the United States," Forum 11, (September, 1891), 501-509; Katherine B. Davis, "The Condition of the Negro in Philadephia," The Journal of Political Economy 8:2 (1900) 248-260.
} 
people of same circumstances." ${ }^{, 18}$ A.J. Chambers similarly instructed the New York Times that he had "never seen anything in the conduct of the colored people here that would cause me to feel ashamed," noting that 3,000 black tourists visited the Jersey shore annually during the summer months. After each visit, Chambers pointed out that Dr. Stokes, President of the region's jubilee association invited the excursion party to return the following summer. In the event that black excursions did become unruly, Reverend Chambers made it clear that African American leaders would not hesitate to discipline such persons if their behavior betrayed the respectable tastes of white and black clientele. "Once this year, when some colored people were a little noisy in seeing some friends off at a station," Chambers recounted, "I spoke from the pulpit about the propriety of good behavior in the street." After the public denunciation, Chambers noted that he had visited the beach every day and "never saw the colored people misbehave themselves there.",19

Other black tourists followed up Chambers' defense of black behavior with incidents of white unruliness. While white tourists and business leaders complained about late-night black entertainments, a "white haired negro" recounted to the New York Times an incident involving the boisterous public performances of the Salvation Army Band. Observing the "noisy dwarf and some young women with tambourines," he noted that "one of the women said that she 'couldn't sing, but she could holler,' and holler she did, like a drunken women." Standing up, other interested observers recalled that the man "raised his cane and said very impressively: "Now will anybody in this crowd tell me whether Asbury Park's colored would disgrace God or man in such a manner as this?"

\footnotetext{
${ }^{18}$ The Sun, June 29, 1887.

${ }^{19}$ New York Times, July 19, 1885.
} 
The reporter who covered the incident wrote that the congregation of black observers stood up and cheered the man, before retiring quietly for the evening. ${ }^{20}$

In making their case for integrated public leisure, black political and religious protestors used moral justifications to defend their rights under the common law. For northern blacks, their ability to access places of leisure revealed the fate of public institutions everywhere and called into question the legitimacy of the common law tradition. Throughout the Civil War era, black activists, litigators, and political leaders struck at the legality of segregated public conveyances and popular amusements by successfully building their cases on the defense of the common law. ${ }^{21}$ While white segregationists attempted to absolve their obligations and duties under the common law by evoking the emerging discourse of individual rights and social propriety, African Americans used Civil War era legal precedent to uphold the legal legitimacy of the common law to repeal segregation in public conveyances and facilities. In a speech given at Oberlin College in 1874, John Mercer Langston explained that the fate of the common law lay in its ability to protect the rights of northern blacks to access popular amusements and other public accommodations. Explaining that common law rules are "explicit and rigid", Langston went on to argue that such complaints by northern blacks for integrated leisure were "indispensable to rational and useful enjoyment of life that without them citizenship itself loses much of its value and liberty seems little more than a crime." ${ }^{22}$ After the Supreme Court ruled in favor of segregationists in 1883, John P. Green, the first

\footnotetext{
${ }^{20}$ Ibid.

${ }^{21}$ A.K. Sandoval-Strausz, "Travelers, Strangers, and Jim Crow: Law, Public Accomodations, and Civil Rights in America," Law and History Review, 23.1 (Spring, 2005); Kelley, Right to Ride; Judith Giesberg, Army at Home: Women and the Civil War on the Northern Homefront (Chapel Hill, 2009).

${ }^{22}$ John Mercer Langston, "Equality Before the Law," In Philip S. Foner, eds., The Voice of Black America: Major Speeches by Negroes in the United States, 1797-1971 (New York, 1972).
} 
black Senator of Ohio, defended the rights of African Americans to regain access to popular amusements. In a speech delivered in May 1884, Senator Green explained that blacks would continue to fight for integrated access under the common law as the "means necessary to the enjoyment of our civil rights. ${ }^{23}$

When Asbury Park Mayor James Bradley moved to enforce segregation in the summer of 1893, northern black lawyers offered similar threats to defend the common law. Speaking to an Asbury Park audience on July 20, 1893, Alfred C. Cowan, a black New York lawyer, explained that James Bradley's ordinances violated Reconstructionera federal statutes along with the laws of New Jersey. Noting that both white or black citizens would have a "good case of action against Mr. Bradley," he called on area blacks to justify integrated leisure by claiming their rights under the 'Fourteenth and Fifteenth Amendments to the Constitution' as well as the civil rights law of New Jersey. ${ }^{24}$ Speaking after Cowan, T. McCants Stewart, a black member of the Brooklyn Board of education and a frequent visitor to Asbury Park, defended Cowan's legal judgment. "He has drawn a distinct color line that the law will not support," Stewart explained, instructing his "good friends, professional and business men in all walks of life" to call the Mayor's bluff. If he insisted on following through on his threat to impose segregation in leisure venues, Steward instructed all area blacks to "call on every provision of the law to ensure that "justice" is restored. Such demonstrations, he insisted, would prove the

\footnotetext{
${ }^{23}$ John P. Green, "These Evils Call Loudly for Redress," in Philip S. Foner, eds., The Voice of Black America: Major Speeches by Negroes in the United States, 1797-1971 (New York, 1972).

24 "Colored People Indignant: Likely to Place Obstacles in Founder Bradley's Way," New York Times, July $20,1893$.
} 
seriousness with which African Americans approached their right to public space and "would make a large hole in his finances" if Bradley continued to refuse service. ${ }^{25}$

Even after the Supreme Court ruled the 1875 Civil Rights Act unconstitutional in 1883 , northern blacks continued to find favorable judges and courtrooms that would decide in their favor. African Americans who lobbied for integrated public leisure at the Jersey shore found occasional legal success by evoking New Jersey's own 1884 Civil Rights law, which prohibited hotels, theatres, restaurants, and graveyard from discriminating against any person based on race. In 1895, Robert Holland, brought James F. Angel, a restaurant keeper of Asbury Park to court after Angel refused to serve him a meal. Ruling in favor of Holland, the court ordered Angel to pay Holland \$1,000 in damages. ${ }^{26}$ Two years earlier, African Americans in Boston found that Massachusetts's own civil rights laws could protect them against hotelkeepers that denied them accommodations. On December 23, 1893, the Worcester Central District Court, ordered Mrs. Mary Place, the owner of the Colenade Hotel, to pay a $\$ 100$ fine for refusing to accommodate the Fisk Jubilee Singers. ${ }^{27}$

At the same time, African Americans who brought business owners and hotel proprietors to court and religious leaders who persuaded others to defend their rights under the common law, stopped short of promoting social equality. While white segregationists at the Jersey shore and elsewhere used the threat of social equality to limit Civil Rights initiatives, black activists appealed to the rights of all citizens to gain access to public spaces, while drawing a line between public and social arenas. A citizen

\footnotetext{
${ }^{25}$ Ibid.

26 "Colored People Aroused: Suits Begun All Over the Country Against Men Who Have Refused to Recognize Their Rights," New York Times, July 26, 1895.

27 "The Cost of Drawing the Color Line," The Boston Transcript, December 21, 1893.
} 
identified as the "Negro Menard" by the Minnesotian-Herald, summarized the position of many black protesters when he claimed "a black man can ride squeezed up by the side of a finely dressed white lady in the street car, and nobody can think anything of it. Is that social equality? Of course not. Street cars are public, not private conveyances. Are theatres public places? Yes." Menard, went on, however, to distinguish between public amusements and private social clubs, noting that "we do not demand admission into the private social circles of whites, but we do demand and intend to gain admission to any seat in the theatre, steamboat, steamcar, hotel, saloon, omnibus, or any other place designed for public accommodation, provided that we pay the common fare."28

African Americans at the Jersey shore evoked the sentiments of Menard by drawing a distinction between public rights and social privacy. In an interview with the New York Times, Alfred Cowan explained that despite white claims to contrary, the boardwalks, beaches, and bathing facilities were not protected by private property claims. "By opening up the beach and the board walk to the public," Cowan pointed out that Bradley "gave an easement to the lessees and owners of cottages and hotels which they had the right to enjoy and which their guests and servants had the same right to enjoy." Yet in pointing out the public functions of such establishments, Cowan stopped short of calling for social equality for black workers. He asserted that "Founder Bradley should have been fair and made his notice read "No servants" allowed. In that case, "no one could have found fault, for there is a distinction in the public mind," he instructed, "between servants and guests at public resorts which all recognize., ${ }^{, 29}$ T. McCants Steward, who agreed that blacks tourists should not be denied public access to leisure

\footnotetext{
28 "The Black and White Problem," Minnesotian-Herald, March 12, 1870.

${ }^{29}$ New York Times, July 20, 1893.
} 
spaces, also stopped short of demanding such rights to the resort community's seasonal laborers. "So far as the colored servants go," Steward explained, "I can understand the desire on the part of Founder Bradley or anybody else to keep them separate...not because they are colored, mind you, but because of the universally accepted idea that the servants should be kept apart from the guests. ${ }^{30}$

As the sentiments of Menard, Cowan, and Stewart demonstrate, the use of the common law defense provided African Americans legal leverage against individual hotel proprietors. In Asbury Park and other northern resort communities, African Americans were granted favorable settlements and allowed integrated access under the common law defense that theatres, hotels, and restaurants served public functions. Yet, the area's leading black legal scholars and civic leaders were hesitant to push for broader social rights. Since the 1830s, African Americans who lobbied for social equality were routinely denied access to public amusements by public officials and private businesses, while courtrooms rolled back Civil Rights laws that sought to dissolve the division between public and private space. Ohio State Senator John P. Green acknowledged this political reality in May 1884, when he explained that African Americans did not look to the government to regulate "matters of a strictly social nature." Every citizen, Senator Green explained, "has a right to select his own company, no gentlemen or lady of color demands or expects any legislation on this behalf, for to do so would be superlative nonsense. ${ }^{\prime 31}$

Lawyers for the Hyer Sisters traveling singing troupe established precedence for this strategy in 1877 , when they declared that the right of the singing troupe to gain

\footnotetext{
${ }^{30} \mathrm{Ibid}$.

${ }^{31}$ John P. Green, "These Evils Call Loudly for Redress," 502.
} 
admittance to northern hotels was not a call for social equality. On September 1, 1877, the Hyer sisters were performing at the Grand Opera House in Indianapolis when they attempted to secure lodging at the accompanying Grand Hotel. When the front desk clerk refused to tender them accommodations, the members of the singing company attempted to enter the Hotel's dining room facilities, but were turned away by a police officer. Charging the hotel with violating section 5.510 of the Civil Rights Act, members of the hotel's management staff were arrested, with bail set at $\$ 400$ each. ${ }^{32}$

In taking the Grand Hotel to court, the Hyer sisters and their legal team declared that their protests reflected the "right to occupy the same places as other freemen in hotels, traveling conveyances and pubic places of amusement." Yet in bringing their suits against the Grand Hotel, the group's manager declared that the Hyer sisters were only "insisting upon its constitutional right. Being placed upon an equality with white men in his privileges at public houses does not place the negro upon social equality with anyone." Differentiating between the dignified behavior and appearance of the Hyer sisters and the area's working-class blacks, the group's manager noted that whites had nothing to fear from the entrance of respectable black entertainers. The "depraved and ignorant," he instructed, would "never be acknowledged the social equals of the virtuous and the intelligent." ${ }^{33}$ On September 3, 1877, the Judge ruled in favor of the traveling musical troupe. By noon the next day, the Cincinnati Daily Gazette reported that members of the musical troop "marched into the dining room and were served a square meal. ${ }^{34}$

\footnotetext{
32 "Civil Rights at Indianapolis," Cincinnati Daily Gazette, September 1, 1877.

33 "The Trouble at the Grant Hotel," Indianapolis Sentinel, September 1, 1877.

34 "That Civil Rights Case," Cincinnati Daily Gazette, September 3, 1877.
} 
The decision by northern blacks to downplay social equality was not just a clever political strategy. Unlike white northerners, who saw any admission of equality as an invitation for political corruption and miscegenation, many black activists did not define integrated leisure as the desire to dine, flirt, or swim with whites. Instead they pressed to partake in these activities without the fear of social pressure or racial exclusion. For black workers and race leaders alike, the freedom of leisure was the right to choose how and where they spent their free time. Integration, as blacks explained, implied the right to choice and the ability to enjoy public venues that the common law and the free market sanctioned.

On August 24, 1888, black tourists ended a pro-longed struggle to close down an "African Dodger" booth in the beachfront community of Gloucester City. A standard carnival game at northern amusement parks, the African Dodger challenged whites to test their accuracy by throwing a series of balls at the live head of a black attendant. For many African Americans who protested the use of the racist "bulls-eye" contest, the "African Dodger" was a familiar visible reminder of the many damaging popular culture images that whites created to degrade black leisure habits and manipulate market behavior after the Civil War. ${ }^{35}$ They argued that the presence of such games was not only a personal affront to the dignity and social status of respectable black tourists, but also a visible political reminder that the cultural authority of Jim Crow rested on its ability to use fraudulent market forces to restrict the entertainment and consumption habits of African Americans.

\footnotetext{
${ }^{35}$ Camden County Courier, August 25, 1888.
} 
Since the antebellum period, northern black intellectuals and political leaders utilized the ideologies of the market revolution to protest economic inequality and racial prejudice. ${ }^{36}$ In a speech given in 1847 , leading black abolitionists called on blacks to challenge the discursive hegemony of Jim Crow and become a "ruler of opinions." Noting that all African Americans "struggled against opinions, the signers of the document exclaimed that "our warfare lies in thought." ${ }^{37}$ As abolitionists and later black civil rights demonstrators knew all too well, an "invisible hand" did not dictate the ability of black northerners to access consumer districts. Instead, blacks took every opportunity to point out that the white business community created and enforced the rules of the marketplace - regulations that rested upon white supremacist images and rhetoric that effectively restricted black recreation. Yet despite these challenges, antebellum black protestors still retained faith in the market to correct itself if certain regulatory features such as racial prejudice could be eradicated. In pamphlets and public speeches, leading black intellectuals routinely embraced the logic of market principles to contest the corrosive regulations that inhibited upward mobility and denied black wage earners from competing in a meritocratic economic order. As Charles Remond explained to the Massachusetts House of Representatives in 1842, segregation enabled the market economy to become corrupted under a system in which "the most vicious is treated as well as the most respectable. ${ }^{38}$ In the emerging Civil rights debates of the Jersey shore during the Reconstruction era, black tourists and seasonal workers called on white segregationists to confront a similar contradiction in the way the free market operated at

\footnotetext{
${ }^{36}$ Patrick Rael, Black Identity and Black Protest in the Antebellum North (Chapel Hill, 2002).

37 "Proceedings of the National Colored People," 1847, in eds., Patrick Rael, Pamphlets of Protest: An Anthology of Early African American Protest Literature, 1790-1869 (New York: Rutledge, 2001), 167.

${ }^{38}$ Charles L. Remond, "Address to a Legislative Committee in the Massachusetts House of Representatives, 1842,” in Liberator, February 25, 1842.
} 
its beach resorts. They asked whites to make a choice between the prejudicial market of Jim Crow and the free market of mass consumption. Were the right of consumers only reserved for white tourists, and if so, how could black workers embrace a free labor system that restricted their ability to enjoy the fruits of their labor?

To combat an economic and social order that denied blacks a place in a meritocratic system, leading black activists at the Jersey shore used the popular press and public political stages to denounce and correct the regulatory prejudices of northern marketplaces. In particular, they refuted the promotional narratives of the Civil War and Reconstruction that white marketing agents and boosters drafted to appease white tourists, and called into question the sincerity of the Republican Party to support blacks' civil rights. In recounting the unofficial means by which skating parlors were segregated in Asbury Park in 1885, W.H. Dickerson insisted that blacks should look cautiously toward their allegiance with Northern Republican leaders. "When we are called on as 'our colored friends'," Dickerson explained, "there is always a purpose to serve as tools or instruments. We would ask those who for many years have been using us to further their plans and fill their coffers," he continued, "if they think we will always remain docile subjects to their dictation and the plain minions of their selfish interests." ${ }^{39}$

Like many white residents had done, African Americans used these incidents and others to give the Civil War and Reconstruction alternative meanings. While white citizens increasingly viewed wartime emancipation as the benevolent gift of white Union soldiers and moderate Republican leaders, African Americans who lobbied for integrated

\footnotetext{
39 “For Our Colored Friends," Daily Journal, July 8, 1885.
} 
leisure at the Jersey shore articulated a more radical history of those years. ${ }^{40}$ Mirroring the complaints expressed by black civil rights protesters throughout the nation after emancipation, Reverend Robinson reminded Asbury Park's white audience of the achievements and struggles of black men who fought to preserve the Union. "We are here," he exclaimed, "to defend our citizenship and our manhood." He reiterated to the white members of the audience that:

We colored people fought for our liberty some years ago, and we do not propose to be denied it at this late date. We will not be dictated to in this manner by $\mathrm{Mr}$. Bradley or any other man. The colored man contributes largely to the wealth of this country, including the town of Asbury Park, and we are here to stay. We fought to save the Union as the white man did. This country is for the whites and blacks alike, including even the beach of Asbury Park. ${ }^{41}$

After James Bradley ordered local police to remove black tourists and workers from Asbury Park's public spaces in 1893, Joseph Francis Smith, a wholesale druggist protested that the move violated the "spirit" of emancipation and the Reconstruction period. "It is pretty late in the day," Smith complained, "for a white man in this part of the country, where the color question has been so freely discussed and so literally agreed upon, to attempt to draw the color line so sharply as Founder Bradley has drawn it." ${ }^{\text {42 A }}$ spokesman for the Fisk Jubilee Singers, offered a similar complaint against white hotel owners who refused admittance to the traveling black troupe in 1877. "It is not only in violation of the law," the spokesman announced, "but of the spirit of the age, which

\footnotetext{
${ }^{40}$ For a sample of the large body of scholarship on race and memory during the Reconstruction period, see David Blight, Race and Reunion: The Civil War in American Memory (Cambridge, 2001); W. Fitzhugh Brundage, The Southern Past: A Clash of Race and Memory (Cambridge, 2005); Andrew Kahrl, "The Political Work of Leisure: Class, Recreation, and African American Commemoration at Harpers Ferry, West Virginia, 1881-1931," Journal of Social History 42 (2008): 57-77; Kirk Savage, Standing Soldiers, Kneeling Slaves: Race, War, and Monument in Nineteenth Century America (Princeton, 1997); Leslie Schwalm, Emancipation's Diaspora: Race and Reconstruction in the Upper Midwest (Chapel Hill, 2009); Nina Silber, The Romance of Reunion: Northerners and the South, 1865-1900 (Chapel Hill, 1997).

${ }^{41}$ New York Times, "Answering Mr. Bradley."

${ }^{42}$ New York Times, July 20, 1893.
} 
recognizes no distinction among men based on color or nationality." Appealing to the better elements of the northern white public to vote down the sentiments, he chastised those who persisted in popularizing "a relic of the race prejudice engendered by slavery," which "all right minded people should assist in frowning down."43

When the Fisk Jubilee Sisters were refused admission to the Troy Hotel in Chautauqua, New York, in December 1885, their manager Henry Cushing again reiterated that the move was "an old story" that did not belong in a post-Civil War world. Charting the troupe's northern touring stops throughout the year, Cushing outlined the racial discrimination they encountered in their travels. In Springfield, Ohio, "the home of Abraham Lincoln," Cushing recounted that the troupe was "refused accommodations in two hotels, and "obtained shelter in the third only on condition that we should hide ourselves from the other guests." While performing at resorts in New Jersey, he acknowledged, "we have been treated more shamefully than we ever were in a southern state." On the other hand, he reminisced fondly over touring stops in Great Britain and "on the continent" where the "slave songs have been sung before nearly every throne" and the troupe were treated as proper guests "at the tables of the noblest houses in England, Ireland, Scotland, France, Germany, and Austria." Demanding that northern establishments acknowledge integrated access to public amusements overseas, Cushing justified the complaints for integrated leisure. "With such remembrances to look back upon," he declared, "we can well afford to treat with contempt, the petty indignities offered by the Troy" hotel proprietors." 44

\footnotetext{
${ }^{43}$ Cincinnati Gazette, September 1, 1877.

44 “Jubilee Singers' Trials,” New York Times, December 25, 1885.
} 
By claiming that their rights as workers and consumers entitled them to integrated leisure, African Americans were often able to attain significant concessions from white businesses and politicians. Reverend J. Francis Robinson informed a congregation of black protesters in 1887 that, despite the presence of signs prohibiting their access, they should continue to resist their exclusion by visiting the beaches after hours. After many black residents heeded his calls, Robinson found that African Americans mingled freely with each other and other white working-class residents on Asbury Park's beaches. As Robinson informed the Daily Journal, "The fact is that neither the paper nor Mr. Bradley can keep us off the beach. I went down there last night and saw some elegant colored ladies. There were Chinamen there too, and Italians."

A few miles inland at the popular town of Red Bank, black protestors mobilized to fight the implementation of segregation ordinances drafted to reassign seating arrangements in local theaters. Noting the domino effect of Jim Crow laws instituted at Asbury Park, local race leaders organized an indignation meeting to instruct local blacks how to refuse instructions to sit in the balconies and upper corners of the area's assorted entertainment venues. Led by Lewis Sommerset, editor of Monmouth County's leading black newspaper, The Mail and Express, members of the meeting expressed outrage that they could no longer "sit where we could pay to sit." Pointing out that the new proprietor of the venue, H.J. Garrity hailed from Asbury Park, "where race prejudice in amusement places is almost as thick to cut with a knife," Sommerset declared that local blacks would not allow similar Jim Crow policies to divide Red Bank's peaceful race relations. Before Garrity's appointment, The Mail and Express declared, “there were not many white

\footnotetext{
45 “Asbury Park's Warfare: Colored People in Mass Meeting Denouncing Mr. Bradley's Actions, New York Times, July 6, 1887.
} 
people who were afraid to sit alongside a decent, self-respecting colored in the opera house or any other place." For those reasons, Lewis Sommerset noted that he would mobilize a series of mass meetings and sit-ins to challenge any policy that refused to acknowledge past interracial precedent. "Colored people have always sat where they wanted to in the opera," Sommerset explained, and “Mr. Garrity's color line will not prevent them for fighting for those rights in the future." 46

The successful application of both violent resistance and peaceful protest allowed African Americans to confidently challenge many of the Jersey's shore's Jim Crow boundaries. In the summer of 1891, the New York Times remarked that "the colored waiters are in hot water" after they refused to put an end to all-night dance parties held in the Convention Hall pavilion. Despite complaints by neighbors and white tourists, African Americans ignored repeated threats by Mayor James Bradley to raid the pavilion if the dancing continued. Indeed, the Times admitted that the "colored people will resist any interference from the authorities," and "there is likely to be a lively time" if African Americans wanted one. ${ }^{47}$ In a meeting protesting Bradley's threats to segregate black workers and patrons from the beaches, Reverend Robinson insisted that "they may put up signs telling us to keep off ... they may put up notices to keep us off the beach," but the Reverend warned, "we will go there just the same. If there were notices tacked up to the doors of hell, telling them not to go there, some of them would because they have a right to go there." In many instances, the complaints were correct. The New York Times reported that three large excursions of black tourists arrived from Newark, Jersey City, and Orange, New Jersey, as well as from New York City and Philadelphia for the annual

\footnotetext{
46 “Jim Crow Theater Seats," New York Times, October 10, 1904.

47 “The Prosperous Season Seems to Have At Last Arrived," New York Times, Aug. 10, 1891.
} 
black "Jubilee day" on July 20, 1887. Ignoring the signs restricting them from the beaches and bathing houses, the black patrons visited the beaches at Ocean Grove and Asbury Park in "droves and sat for several hours on the sand." In addition, "a dozen or so" applied for bathing suits at the bathhouses, but were refused. In each instance, the Times reported that the patrons took the refusal of service in "good spirits," but remained nonetheless. $^{48}$

White citizens also quickly discovered their limitations in enforcing segregation ordinances in Atlantic City. During the summer of 1890, the Washington Post complained that "local blacks by the hundreds were invading the bathing districts heretofore patronized by the best visitors." Off the beach, the article noted that the situation was "similarly lax." "After the colored waiter serves his master's supper," the columnist explained, "he can go out and elbow him on the boardwalk, crowd him in cars, or drink at the very next table in almost any café. ${ }^{49}$ Responding to the Philadelphia Inquirer's plea to "keep blacks in their place," the Atlantic City Daily Union admitted that only the "collaboration of all the beachfront proprietors could keep the blacks in their place, a collaboration which (one suspects) was unlikely., 50

The refusal by black northerners to abide by the segregation statutes not only spoke to their desire to maintain their moral dignity and assert their postwar claims to rights as citizens and workers for leisure time, but also reflected their claims to consumer rights. As these black workers and tourists at the Jersey shore argued, they not only wanted to "joy their freedom," but also desired the assigned cultural status that access to

\footnotetext{
48 "Their Jubilee Day," New York Times, July 21, 1887.

49 "Washington Post Complained," Atlantic City Daily Union, July 23, 1900.

50 "What Are We Going to Do?" Atlantic City Daily Union, July 23, 1893.
} 
leisure time and space provided. ${ }^{51}$ For black and white citizens in the post-Civil War North, public space was the proving ground for citizenship and social affirmation of individual rights. While white citizens sought to group all African Americans within a subaltern racial class, black workers and tourists insisted that they were autonomous individuals capable of competing in a free labor system and enjoying their rights as consumers in a responsible manner. At the same time, engaging in leisure and recreational activities was not only an individual act of freedom but also an explicitly communal activity that white northern citizens thought should be enjoyed in the company of others. Both white and black citizens lobbied with each other for inclusion and acceptance as persons worthy of leisure time and space. Just as white, working-class tourists desired the acceptance of their middle-class "betters," black citizens sought the public approval of white northern tourists to establish their social position and permanent citizenship. This self-conscious sensibility dictated social rules and reinforced the region's cultural values that all citizens sought to emulate. As the noted literary critic and shore correspondent Stephen Crane observed, the guests of the Jersey shore came not for the "sea nor the cacophonous brass bands," but rather "to see the people, for there is joy in the heart of the crowd." ${ }^{, 52}$

By staging public protests against white business owners and local officials, blacks at the New Jersey shore transformed the segregation debate by destabilizing the cultural symbols and texts that shaped the region's legal and social rules. Whereas whites sought to legitimate segregation as a system that the invisible hand of the market - and not the personal prejudice of northern citizens - sanctioned, African Americans argued

\footnotetext{
${ }^{51}$ Tera Hunter, To 'Joy My Freedom: Southern Black Women's Lives and Labors after the Civil War (Cambridge, MA, 1998).

${ }^{52}$ Stephen Crane, "On the Jersey Coast," New York Tribune, July 24, 1892.
} 
that the postwar northern marketplace carried specific racial values that often trumped its supposedly neutral ones. They reiterated to those who sought to deny them their right to leisure space that race had an economic value in the postwar north that prevented citizens - even those with the financial means - from taking part in a rapidly expanding mass consumer society on account of race. In a short speech protesting the emerging segregation laws in Asbury Park, Robinson spoke of the discriminatory language of Asbury Park's Daily Journal, whose resentment and prejudice encouraged "one to think it was edited in Georgia." Robinson explained that "at a place set apart for temperance and religion we witness a spectacle that should shame the boasted civilization of the North. Let us devote ourselves to stripping off false religious sentiment and hypocritical philanthropy, that we may expose before the people just how far race hatred can go in New Jersey." Fellow A.M.E. Minister, Rev. H.H. Monroe of St. Mark's Church, similarly remarked that talk of exclusion and separation "would be bulldozing if it was reported from Texas," and pointed out that in many northern public spaces devoted to leisure and consumption, the same "ante-war spirit of race distinction still prevailed."

By nationalizing the problem of segregated leisure, black northerners contributed to the postwar tradition that white industrial workers in the 1860s and 1870s initiated in arguing for "eight hours for what we will." ${ }^{54}$ Yet, while many industrial laborers rejected the consumption habits and amusement venues of New England's leisure class, black workers and tourists who traveled to the New Jersey shore claimed those cultural spaces as their own. "Let the necessity of labor," W.M Dickerson instructed, "never take away a

\footnotetext{
${ }^{53}$ Ibid., "Asbury Park's Warfare."

${ }^{54}$ Roy Rosenzweig, Eight Hours For What We Will: Workers and Leisure In An Industrial City, 1870-1920 (Cambridge, 1983); Kathy Peiss, Cheap Amusements: Working Women and Leisure in Turn-of-the-Century New York (Philadelphia, 1986); Nan Enstad, Ladies of Labor, Girls of Adventure: Working Women, Popular Culture, and Labor Politics at the Turn of the Century (New York, 1999).
} 
person's claim to respectability. One's ability to board at a hotel and dress well is no criterion of one's moral worth. ${ }^{, 55}$ Reverend Robinson of the A.M.E. Church in Asbury Park instructed the town's white boosters that the "poor colored people did as much for the prosperity of the park as the poor whites, and yet the poor whites wanted protection from them. ${ }^{, 56}$ Andrew Chambers, writing in the Christian Recorder, mirrored Reverend Robinson's complaints. Chambers challenged Bradley and others to answer, "To whom are we a source of annoyance? To whom are we an offense and an eyesore?" Noting the interracial contact between black domestic workers and white tourists throughout the town's business establishments, Chambers answered that "it surely cannot be those whom we pass the butter dish in hotels and boarding houses," since he pointed out, "if it were, then they would seek other resorts, if it be possible for them to find anywhere they will not find some of us." ${ }^{57}$

The debate between segregationists and northern blacks reflected broader nineteenth-century struggles over the category of the "social" in deciding the rights of consumers and shaping the political vocabulary of segregation. Throughout the nineteenth century, legal rulings evoked the defense of the social to justify the exclusion of blacks and other outsiders - especially those who lobbied for rights that the marketplace had supposedly denied. ${ }^{58}$ According to James Bradley and other business owners of the Jersey shore, such measures were legitimate regulations not because they were motivated by racial prejudice, but because they were sanctioned by the economic realities of leisure enterprises - a special circumstance that allowed all public and

\footnotetext{
55 “A Colored Man's View," Daily Journal, August 12, 1886.

${ }^{56}$ Ibid., "Answering Mr. Bradley."

57 "A Travesty Upon Justice and Truth," The Christian Recorder, Aug. 6, 1885.

${ }^{58}$ Saidiya Hartman argues that the "social" in nineteenth century political thought encompassed an "asylum of inequality." Hartman, Scenes of Subjection, 201.
} 
commercial space to fall under the realm of the social, thereby officially eliminating the "public" sphere until it was permanently privatized. ${ }^{59}$

Black workers and tourists, on the other hand, argued for a limited definition of the "social," one that reflected the public and democratic nature of the old common law tradition, while also allowing them freedom of movement and the right of "choice" they had come to believe was inherent in a consumption-oriented market economy that northern Republicans had championed throughout the Civil War era. Writing in the Christian Recorder on August 3, 1893, J.H. Morgan offered an alternative solution to the values northern whites attached to the common law and the postwar marketplace. "We think Mr. Bradley's position is better illustrated," Morgan instructed, "by a party who owns a house and turns it into a public inn for the accommodation of the public," with the exception, Morgan acknowledged, "of ejecting all disorderly and obnoxious persons, but not simply on the ground of color."60

The right of African Americans to enjoy integrated leisure accommodations was important to many blacks because it defended the right of choice many believed was integral to preserving an open marketplace. In redefining the legal and ideological parameters of public and private in a free market system, blacks and whites reached opposing definitions of choice. Northern whites believed that the market permitted segregation because its economic sanctions and regulations were based on social tastes and public opinion, a feature of the market, which if deregulated, would erode the moral

\footnotetext{
${ }^{59}$ The impact of commercialization on the Gilded Age public sphere is well documented. Few of these works, however, address the influence of northern race relations in reconfiguring the ideological and political parameters of public and private space. See, William Leach, Land of Desire: Merchants, Power and the Rise of a New American Culture (New York, 1994); Mary P. Ryan, Civic Wars: Democracy and Public Life in the American City during the Nineteenth Century (Ithaca, 1992); David Scobey, Empire City: The Making and Meaning of the New York City Landscape (Philadelphia, 2002); Alan Trachtenberg, The Incorporation of America: Culture and Society in the Gilded Age (New York, 1982).

60 “Asbury Park Colored Question," The Christian Recorder, August 3, 1893.
} 
foundations of civil society. Black protestors, however, believed the right of consumer choice was absolute, and that to deny such rights, would allow other industries to promote racially restrictive covenants. In an editorial to The Sun, a black visitor to Asbury Park remarked that the right of consumers to make unregulated choices was a basic civil right. "If seats are provided for the public, the unnamed visitor to Bradley's resort noted, "the colored people have as much right to them as the white people. First come first served must be the rule, and whoever finds an empty seat is at liberty to take it, whatever his complexion." Noting the insistence by many whites that private property precluded demands for integration, the editorial forcefully declared that the religious origins of towns like Asbury Park disallowed such harsh measures. "Nor even if they are private property," the visitor exclaimed, "is it possible to make any reasonable discrimination against their use by decent color people.",61

To counter the Jim Crow sentiments and segregation laws, many working-class African Americans also resorted to a variety of infrapolitical tactics and strategies to desegregate the region's public sphere. Although many black tourists and working-class men and women faced increasing restrictions in accessing the Jersey shore's public and commercial spaces, they still had the freedom, in Michel de Certeau's words to "poach." Poaching, as Certeau explains, allows restricted groups to manipulate official readings into subversive ones. ${ }^{62}$ By intruding in spaces white citizens had deemed off limits to black visitors, African Americans stripped those spaces of their cultural value, and, as a

\footnotetext{
${ }^{61}$ The Sun (NY), June 29, 1887.

${ }^{62}$ Michel de Certeau, The Practice of Everyday Life (Berkeley, 1984). My conceptual understanding of infrapolitics is also drawn from the work of Robin G. Kelley, Stephen Hahn, and James C. Scott. See, Robin D.G. Kelley, Race Rebels: Culture, Politics, and the Black Working Class (New York, 1994); Stephen Hahn, A Nation Under Our Feet: Black Political Struggles in the Rural South from Slavery to the Great Migration (Cambridge, 2003); James C. Scott, Domination and the Arts of Resistance: Hidden Transcripts (New Haven, 1992).
} 
result, their economic value. In 1893, the Atlantic City Daily Union reported that after a black waiter became disgruntled with the food options available to him during his shift he decided to order a meal from the main menu. Upon refusing the waiter's request because the menu was off limits to black workers, the waiter rounded up the wait staff and walked out. ${ }^{63}$ A similar demonstration took place when black workers at the Albion Hotel in Atlantic City walked off the job to help secure better wages and integrated access to the hotel's leisure accommodations during their free time. ${ }^{64}$

In even less visible ways, many black service workers deployed what Clifford Geertz has termed different "scripts" or cultural protocols that depended on the audience. $^{65}$ As one Atlantic City black worker explained, a waiter might act the role of a dutiful servant in front of white patrons, but back in the kitchen, he or she often resorted to more subversive and rebellious behavior. A black college student who waited on white guests in Atlantic City recounted, "We suffered from rude or half drunk guests who called us degrading names because of our color. We could in a way always get back at them. We could spit in their soup or in their beer ... Rebellion caused us to think of ways to get even the very minute we stepped on the floor." ${ }^{, 66}$ For these and other black domestic workers, consumer culture offered a way to reject both the class ideologies that black political leaders sometimes defended and the ideologies of the marketplace that white, middle-class northerners assigned to the northern public sphere in defense of segregation.

\footnotetext{
${ }^{63}$ Atlantic City Daily Union, June 14, 1893, 1.

${ }^{64}$ Atlantic City Daily Union, Aug. 11, 1899.

${ }^{65}$ Clifford Geertz, Negara: The Theatre State in Nineteenth Century Bali (Princeton, 1980).

${ }^{66}$ William M. Ashby, Tales Without Hate, (Newark, 1980), 36-37.
} 
These political protests proved that while capitalist culture could sometimes serve to undermine and limit the rights of African Americans to access northern amusement venues, it also provided many black seasonal laborers with unique opportunities to reconfigure the Jim Crow debate. By relying solely on black seasonal labor, civil rights protests from black northerners made the project of Jim Crow in the North-particularly in places along the New Jersey shore—as difficult for northern business owners and politicians as it did for those in the South. While many white northerners might have viewed black industrial laborers as a threat to white wages and free labor ideology, as David Roediger and Heather Cox Richardson argue, the demands of a service economy placed greater restraints on the marketing agents and proprietors of leisure venues than they sometimes did for other northern capitalists. ${ }^{67}$

As producers of a popular culture landscape dedicated to amusement and mass consumption, as well as consumers whose spending and social habits threatened the tastes and customs of a northern Jim Crow culture, black tourists and seasonal workers found themselves in a unique position to challenge and undermine the cultural hierarchies and legal boundaries of segregation that often restricted the consumption habits of most northern black laborers. James Bradley, for example, acknowledged that many families left his resort because they could not "endure the crowds of Africans infesting every promenade and public space, day and evening with their presence." ${ }^{98}$ After the barroom brawl at Asbury Park's Plaza Hotel in 1893, the hotel's proprietor remarked that his decision to readmit the black waiters came after he was unable to persuade whites to dine in the hotel. Many families, Proprietor Bly noted "have been compelled to get their meals

\footnotetext{
${ }^{67}$ Roediger, Wages of Whiteness; and Richardson, The Death of Reconstruction.

68 "It Must Be Stopped," Daily Journal, July 30, 1886.
} 
elsewhere, as the waiters would not allow any one to enter the dining room to serve the families. ${ }^{.69}$

As a result of these protests, James Bradley was forced to assemble Asbury Park's black civic leaders and working-class residents to town hall meetings throughout the 1880s and 1890s to reassure his black constituents and seasonal laborers that such decisions were not made to appease his personal prejudices, but enacted as a last resort to protect area businessmen who relied as much on seasonal white tourists as he did on black service workers. ${ }^{70}$ Speaking to local audiences in Asbury Park, Red Bank, and Long Branch, Bradley attempted to win local black support by hosting elaborate galas and allowing black audiences a chance to voice their concerns. The move backfired, however, when many northern black voters believed Bradley was resorting to bribery to retain black support. Members of the black press criticized the events as an attempt to "draw the wool over their eyes" with music and refreshments. Criticizing "Founder Bradley's case" in The Sun on October 3, 1893, New York civil rights leaders challenged black voters at the Jersey shore to protest the events and defeat him at the polls. "They ought to vote against him, and knock him out at the polls," the editorial declared, not only because of his segregation policies, but also "because of his conduct since he became a candidate for political office." ${ }^{, 71}$ Speaking at a final campaign stop in Long Branch on November 2, 1893, Bradley began speaking when a black voter sprang to the podium and listed the offenses Bradley's Jim Crow ordinances rendered against local blacks. Following the protestor, several black preachers and lawyers also took the stage and

\footnotetext{
${ }^{69}$ The Evening World, August 4, 1893.

${ }^{70}$ Ibid., "Founder Bradley Explains."

71 "Founder Bradley's Case," The Sun (NY), October 3, 1893.
} 
called on the black voters in attendance to refuse Bradley's appeals for support and reject his candidacy. ${ }^{72}$

The politics of segregation in leisure settings thus offered black seasonal laborers and community leaders an opportunity to engage in political issues of regional and national significance that were often denied to them by mainstream northern politics. While black intellectuals and national Civil Rights leaders struggled to overturn Jim Crow laws throughout the country, black tourists and working-class individuals at the New Jersey shore employed an array of successful strategies and tactics to upset the social and legal boundaries that many white northerners fought to maintain throughout the late-nineteenth century. By lobbying local Republican officeholders, engaging in infrapolitical protests, and challenging the rhetorical cover of white supremacy that many white northerners deployed in the northern press to justify segregation laws, black seasonal laborers and tourists helped make issues of leisure, entertainment, and consumption indispensable from other educational, electoral, and economic concerns that preoccupied the nation's more famous black political figures. In doing so, they made sure that free labor ideology could not be reinterpreted to exclude black recreation or to forestall political decisions on the rights of consumers. Instead, by occupying the Jim Crow spaces of the region, they actively fought to reshape segregation policy—and won—by consistently calling on white segregationists to institute a more democratic form of market capitalism that defended the rights of all consumers.

\footnotetext{
${ }^{72}$ The Sun, November 2, 1893.
} 


\section{Chapter 3: Marketing and Managing Segregation, 1893-1900}

On October 24, 1893, James Bradley invited the region's black population to the Red Bank Opera House to explain to those who had protested his segregation laws that he was "not opposed to the colored man." Addressing three hundred and fifty local black residents and workers, Bradley argued that the notices outlawing blacks from the town's public and commercial spaces were posted because "boarders refused to mingle with the colored folks." Reminding those assembled that he was a "Republican from head to foot," Bradley attempted to justify to the congregation that he "did not post the notices to offend the Negroes," but did so to protect the economic interests of area businesses that employed many blacks. ${ }^{1}$ James Bradley's attempt at reconciliation reveals the political dilemma many northern business owners and tourist promoters continued to face in marketing and managing segregation after Reconstruction.

To local Jersey shore businessmen, the prospect of free consumption in the name of black civil rights threatened to be every bit as revolutionary as free labor ideology had been for southern merchants and planters after the Civil War. Thus, by the early 1890s, white politicians, marketing agents, and business owners were at a crossroads in their attempts to implement Jim Crow laws. If they were going to proceed with a stricter segregation policy — as their public notices indicated - they had to decide how to promote and justify Jim Crow in a way they had been unable to do throughout the 1880 s. Since 1885, white tourists consistently complained about African Americans overstepping their bounds by frequenting area boardwalks, beaches, and amusement facilities during peak leisure hours. In an effort to keep the peace, many Jersey shore officials adopted a policy of moderation. Attentive to the racial sensibilities of the town's black patrons and the

\footnotetext{
1 “Founder Bradley Explains," New York Times, October 24, 1893.
} 
"spirit of the times," Bradley and others avoided bold declarations couched in racial tones by drafting notices that asked for, rather than demanded compliance. In a placard placed above one of the town's bathing pavilions in 1892, Bradley drafted the following plea: "Colored persons are asked not to occupy this pavilion." ${ }^{2}$ As his remarks to area blacks at the Red Bank opera house had indicated, Bradley preferred to appeal to African American clergy and business leaders to discipline noncompliant working-class blacks. Admonishing the black working-class for ignoring his good will gestures and projects, he informed the congregation's leaders of donations to local Jubilee singers, Asbury Park's first black church, and the many "needy colored persons" who he befriended and employed. ${ }^{3}$ Yet to black tourists and workers committed to integration, the language and instructions of the signs reflected a confession of weakness, inviting many black consumers to ignore warnings they believed were not accompanied by the threat of declarative and legitimate force.

By 1893, James Bradley decided he needed to be bolder in enforcing his segregation laws. When black workers and tourists continued to violate his ordinances in the opening weeks of the 1893 summer season, Bradley commissioned law enforcement personnel to police the Jim Crow areas and eject any black individual found violating the written notices. In an interview with the New York Times, James Bradley reflected on his decision. "At first I paid little attention to these complaints," he explained, "but when they became so numerous that I was compelled to give up several hours a day to listen to them, I decided it was time to act."

\footnotetext{
2 "Color Line at Asbury Park: Negroes Who Go on the Pavilion Will Be Arrested," The Evening World (NY), July 18, 1893.

${ }^{3}$ New York Times, October 25, 1893; "Founder Bradley's Case," The Sun (NY), October 3, 1893.

4 “Asbury Park's Pavillions," New York Times, June 4, 1894.
} 
Throughout the Reconstruction era, vacation destinations exposed the ambiguous state of whiteness in ways incomparable to other public settings. As a result, most scholars have focused on the political and racial claims of tourists, arguing that the implementation of Jim Crow segregation in postwar leisure communities arose from an uncertain white supremacy. ${ }^{5}$ However, for the business owners and politicians who ultimately drafted and adopted Jim Crow measures at the Jersey shore, the decision to act in favor of segregation was not made solely to strengthen or rescue white tourists' fragile sense of race. As the political campaigns of black consumer activists made clear, the promotion of mass consumption during the late-nineteenth century made business owners, marketing agents, and local officials vulnerable to charges of economic hypocrisy from African Americans - and potentially other consumer rights groups who attacked or subsequently might attack proprietors for condoning an inconsistent application of capitalist principles. In the years after the 1893 segregation notices were accompanied by police power, Bradley and other local authorities developed a Jim Crow strategy built around a defense of market values and public propriety, necessary

\footnotetext{
${ }^{5}$ The intersection of race and recreation in northern leisure resorts is explored in a number of important works. See, Catherine Cooks: Doing the Town: The Rise of Urban Tourism in the United States, 18501915, (Berkeley, 2001); John Sterngrass, First Resorts: Pursuing Pleasure at Saratoga Springs, Newport, and Coney Island (Baltimore, 2001); Cindy Aron, Working at Play: A History of Vacations in the United States (New York, 1999; David Nasaw, Going Out: The Rise and Fall of Public Amusements (Cambridge, 1999). A public defense of whiteness as the primary catalyst for segregation remains the standard explanation for the maintenance of Jim Crow after the Civil War. See, George Fredrickson, The Black Image in the White Mind: The Debate on Afro-American Character and Destiny, 1817-1914; David Roediger, The Wages of Whiteness: Race and the Making of the American Working-Class (New York, 1991); Alexander Saxton, The Rise and Fall of the White Republic: Class Politics and Mass Culture in Nineteenth Century America, Matthew Frye Jacobson, Whiteness of a Different Color: European Immigrants and the Alchemy of Race (Cambridge, 1999); Noel Ignatiev, How the Irish Became White (New York, 1995); Thomas C. Holt, "Racism and the Working Class," International Labor and Working-Class History, 45 (1994); Andrew Neather, “' 'Whiteness' and The Politics of Working-Class History," Radical History Review, 61 (1995); George Lipsitz, The Possessive Investment in Whiteness: How White People Profit from Identity Politics, (Philadelphia, 1998). In recent years, a few historians have offered critical rebukes of whiteness studies. See esp. Eric Arnesson, "Whiteness and the Historians' Imagination," International Labor and Working-Class History, 60 (2001): 3-32; Peter Kolchin, "Whiteness Studies: The New History of Race in America," Journal of American History, 8.1 (June, 2002).
} 
regulations that they believed would prevent a whole-sale disintegration of core capitalist principles and Victorian assumptions of respectability. Thus, while black consumer activists argued for unlimited consumer access, local authorities insisted that only proprietors could grant such rights. In doing so, they attempted to make the segregation debate about political economy instead of race, castigating black consumer activism as a disruptive social act that threatened the popularity and financial growth of the region. ${ }^{6}$

The decisions undertaken by white authorities to regulate beaches and boardwalks highlight as well the complicated legal world that businesses inhabited following Reconstruction. While federal court decisions overturned the Reconstruction era's more radical civil rights laws, subsequent state laws were quickly implemented throughout the 1880s to corroborate the decisions of the Fourteenth Amendment and the defunct 1875 Civil Rights Act. These rulings not only threatened to restrict the ability of local authorities to decide racial policy, but were equally burdensome for business owners who long cherished the right to personally regulate marketplace exchanges. In facing a hostile legal environment that increasingly privileged the rights of consumers-white and black - business owners at the Jersey shore struggled to retain moral and political claim to their property. It was within this political backdrop that segregation was implemented and enforced during the 1890s. In justifying the enforcement of segregation notices, area merchants laid claim to local social precedent that operated outside the formal restrictions of state and federal jurisdiction and overrode the buying power of consumers; a process

\footnotetext{
${ }^{6}$ My understanding of Jim Crow's origins at the Jersey Shore is taken, in part, from Heather Cox Richardson's arguments about the northern retreat from Reconstruction and Amy Dru Stanley's work on Gilded Age contract law. Both argue that ideas about political economy, and not just racism, contributed to northern efforts to ostracize political opponents and discredit civil rights. Heather Cox Richardson, The Death of Reconstruction: Race, Labor, and Politics in the Post-Civil War North, 1865-1901 (Cambridge, 2001); Amy Dru Stanley, From Bondage to Contract: Wage Labor, Marriage, and the Market in the Age of Slave Emancipation (New York, 1998).
} 
that offers a prescient reminder about the cultural hegemony of marketplace ideas in shaping a color-blind liberalism during the early Jim Crow era. ${ }^{7}$

The late-nineteenth century was a rare time of both unprecedented legal victories for African Americans and racial confusion for northern whites. No other period since the American Revolution witnessed as dramatic a granting of rights and privileges as the late 1860s and 1870s did. Even after the Supreme Court ruled most of the period's more progressive Civil Rights laws unconstitutional in 1883, several states, including New Jersey, circumvented the Court's ruling by passing their own Public Accommodations laws, permitting local blacks to sue proprietors who refused them access to public institutions and popular amusements. For these reasons, Eric Foner has famously declared Reconstruction a revolutionary era; a time when nineteenth-century AfricanAmerican claims to freedom, citizenship, and access to political power knew few limits. ${ }^{8}$ For northern whites, however, the Reconstruction period signaled an ambiguous new era in which laws no longer controlled social interaction or racial customs. At a time when many whites were obstructed by a revised narrative of "rights" that no longer privileged whiteness, they saw the law as subverting the customs and rules of etiquette that governed social boundaries in other public and private spaces. By the $1880 \mathrm{~s}$, northerners began to turn away from the courtroom to control social and racial boundaries. The preference by northern whites to adjudicate interracial interaction through informal means did not mean that the law did not play a leading role in mediating

\footnotetext{
${ }^{7}$ Charles Mills, The Racial Contract, (Ithaca, 1997); Shannon Sullivan and Nancy Tuana, Race and the Epistemologies of Ignorance, eds. (New York, 2007); David Theo Goldberg, The Threat of Race:

Reflections on Racial Neoliberalism (Malden, MA, 2009); Eduard Bonilla-Silva, Racism Without Racists: Color-Blind Racism and the Persistence of Racial Inequality in the United States, (Lanham, MD, 2003).

${ }^{8}$ Eric Foner, Reconstruction: America's Unfinished Revolution (New York, 1998).
} 
political and physical boundaries. Throughout the nation, a host of legal statutes segregated schools, public accommodations, restricted interracial marriage, and denied the vote to countless numbers of African Americans. As Ariela Gross writes, "Jim Crow was not just an ideology, it was a set of laws." ${ }^{, 9}$ At the same time, in many public and commercial spaces, northerners turned to the cultural laws of the period to justify and enforce segregation. This was particularly true in leisure settings. While summer vacations could serve to relax some social standards, they also served to re-negotiate and harden others. If there were too few restrictions and rules, white northerners believed the race, class, and gender hierarchies that governed daily life outside of the Jersey shore might also be overturned. In a postwar public of social counterfeits whose racial identity could not be determined by sight alone, northern business leaders and tourists turned to the written and visual images of Gilded Age culture to market and define the color line in leisure communities.

The proliferation of etiquette manuals and advice literature provided a convenient device for justifying segregation without admitting racial preferences. Public complaints from white tourists throughout the postwar period revealed that they took this advice as serious guidelines for dealing with unruly blacks that refused to comply with segregation statutes. ${ }^{10}$ Explaining the utility of etiquette, Timothy Howard instructed northerners that "a nation is a number of people associated together for common purposes, and no one can question the right of those people to make laws for themselves." To those black

\footnotetext{
${ }^{9}$ Ariela Gross, What Blood Won't Tell: A History of Race on Trial in America (Cambridge, 2008); Leon Higginbotham, Jr., Shades of Freedom: Racial Politics and Presumptions of the American Legal Process (New York, 1996).

${ }^{10}$ The importance of advice literature in directing social boundaries during the late-nineteenth century is explored in a few popular works. See, John F. Kasson, Rudeness and Civility: Manners in NineteenthCentury Urban America (New York, 1990); Saidiya Hartman, Scenes of Subjection: Terror, Slavery, and Self-Making in Nineteenth Century America (New York, 1997).
} 
northerners who felt themselves wronged by the emergence of segregation, Howard cautioned that "no one, however fine his education, or however great his wealth, power, or fame, should feel himself wronged in the least if this society refused him admission until he has made himself fully acquainted with the laws." ${ }^{11}$

Mirroring the sentiments of these advice guidelines, northern business owners and local civic leaders rejected the notion that segregation violated the spirit of emancipation. Instead, they argued that Gilded Age etiquette laws helped police social arenas that neither legislation nor legal rulings could effectively govern. Those who agreed with Asbury Park's Jim Crow ordinances routinely pointed out that blacks were not the only ones who were forced to abide by Bradley's rules. In defending Bradley, the New York Times explained, "after getting to the beach," all visitors "found that they could remain there only by doing precisely as Mr. Bradley wanted them to." If you combed the town, the Times instructed that both blacks and whites would find "numerous printed cards with specific rules and regulations," informing visitors "that they must not peddle anything, must not use profane language, must not wear bathing suits open to a suspicion of immodesty, must not pose in attitudes that might be considered questionable, must bathe within certain hours, and on Sundays not after 8am." ${ }^{, 12}$

Aside from these formal declarations, local officials pointed out that the public was also informed that "most respectable people would wish to be off the promenade by 10:30pm." This last point was an instructive one when it came to justifying segregation.

\footnotetext{
${ }^{11}$ Timothy Edward Howard, Excelsior; or, Essays on Politeness, Education, and the Means of Attaining Success in Life, Part I (Baltimore, 1868); Our Manners at Home and Abroad: A Complete Manual on the Manners, Customs, and Social Forms of the Best American Society (Harrisburg, 1883), quoted in Kasson, Rudeness and Civility, 60.

12 "Drawing the Color Line at Asbury Park: Negroes Who Offend the Residents of Asbury Park," New York Times, July 19, 1885.
} 
In order to be incorporated into polite society, Gilded Age Victorians believed that citizens needed to have a familiarity with society's discourse and customs; an informal set of guidelines that instructed decent and respectable people in the appropriate social rules to follow besides the formal laws of a given place. In taking stock of Bradley's rules, the Times reported, "the majority of white people observe them, so that Mr. Bradley has little cause for complaint. Yet, "not so it is claimed with the colored folks." Frequent visitors recounted to the Times that too many blacks "do not read the rules, and consequently do not obey them."13

In permitting African Americans to congregate in Asbury Park's public venues after 10:30pm, Bradley avoided civil rights complaints from most local blacks. Yet in choosing 10:30pm as the designated Jim Crow time, he conveniently placed African Americans in a precarious predicament. If they followed Bradley's stated rules and isolated themselves from the beaches and boardwalks until after 10:30pm, they would remain in compliance with the law and not risk further restrictions. Yet by socializing in public after 10:30pm, they risked the cultural stigma of violating the informal laws and customs that marked late-night recreation as unruly, dangerous, and immoral.

Bradley's clever manipulation of law and custom was part of a broader effort on the part of northern whites to downplay charges of racism that emanated from black protests, and instead to justify stricter social regulations as consistent with market principles. To do so, Bradley and other white segregationists rewrote the origins of Jim Crow by castigating black political activists as the perpetrators who destroyed the prospect of future interracial cooperation in leisure resorts. "It has always been custom," many whites admitted in recounting the offenses of blacks, "to allow them considerable

${ }^{13} \mathrm{Ibid}$. 
liberty." Indeed, few visitors remembered a time when black workers and tourists had not "mingled freely on the beach, disported in the surf, skated in the rinks, and rolled baby carriages in the avenues." These reshaped narratives thus told a story of discontinuity, in which, as Bradley explained, a period of peaceful interracial cooperation in public leisure spaces was interrupted when a new coalition of African American activists proved themselves unfit for unregulated social interaction. "The result has been," the New York Times noted in 1885, "that white guests have complained to hotel keepers that colored persons were overstepping their bounds, intruding themselves in places where common sense should tell them not to go, and monopolizing public privileges to the exclusion of whites." ${ }^{14}$ In 1890, the Times again noted that debates over integration came down to the "presumption of some of the colored people who offensively assert themselves where they are not wanted." 15

For many whites, African Americans' inability to abide by what they termed "common sense," reaffirmed their belief that most black consumers were incapable of understanding the social prerequisites for admission into public leisure space. In observing the inability of black civil rights demonstrators to conform to the social standards of Gilded Age advice literature, whites came to see black behavior as strange, grotesque, and politically dangerous, requiring the permanent implementation of segregation until blacks could prove themselves worthy of integration. Just as the recreational activities of African Americans after 10:30pm reaffirmed whites' attitudes toward black's social habits, the large excursions of black tourists in September also served to exacerbate racial feelings toward black leisure and further justify segregation.

\footnotetext{
${ }^{14}$ Ibid.

15 “Asbury Park: Colored Question Settled,” New York Times, July 20, 1890.
} 
"One of the harbingers of fall," the Philadelphia Inquirer exclaimed in September 1896, is the "annual excursion of colored citizens from Philadelphia, Delaware, and New Jersey to the seashore." However, unlike the articles that appeared in the Inquirer in June and July, which noted the daytime theatrics of the city's nobility, regional coverage of black excursions emphasized the comical "antics" of African-American tourists whose behavior was "excruciatingly funny and furnished a fund of amusement to the whites who visited the vicinity out of curiosity. ${ }^{, 16}$ Covering the excursions of black tourists in September 1898, the Philadelphia Record spoke to one observer who noted "their white brethren enjoy the antics of the naturally care-free colored folks...their dark faces smiling all the time and the picturesque costumes of women with their great love of color and sensuality interested and amused the spectators."17

Reports of black leisure were also often undercut with a foreboding sense of danger, criminality, and lewdness. A visitor who came to amuse himself with the sights of black vacationers pointed out that one particular beach in Atlantic City was littered with black women in "grotestque" costumes. However, he acknowledged that he was disappointed that he did not get to witness the gangs of unruly blacks he was promised. "There were very few arrests made," he admitted, and "the race weapon, the 'razor,' was conspicuously absent. ${ }^{" 18}$ One of the revealing observations made in these reports was the characterizations of black women as "picturesque" and "grotesque," whose apparent "sensuality" displayed for many whites an unfamiliarity—and perhaps worse, neglect— among blacks in general, with Victorian notions of respectability. This stood in contrast to the evolving perception of white women throughout the late-nineteenth century. In

\footnotetext{
16 "City by the Sea: Excursion to Atlantic City," Philadelphia Inquirer, September 6, 1896.

${ }_{17}^{17}$ Philadelphia Record, September 4, 1898; Philadelphia Evening Bulletin, September 8, 1905.

${ }^{18}$ Philadelphia Inquirer, September 6, 1896.
} 
unprecedented numbers, working-class women demanded greater access to recreational venues, frequenting dancehalls, amusement parks, beach towns, and eventually movie theatres throughout the Gilded Age. These new women—independent, promiscuous, and decidedly modern — recast leisure spaces and codes of etiquette once reserved for men. Labeled "rowdy girls" by Progressive reformers, working-class women told risqué jokes, swapped stories about their sexual experiences, and courted male companions in open defiance of conventional protocol. ${ }^{19}$

Despite the success working-class women achieved in popularizing and legitimizing leisure time for themselves, Gilded Age stigmas on un-occupied and unchaperoned women still prevailed, attaching themselves to a growing public concern about the proliferation of commercial sex and making it that much harder for workingclass black women to enjoy their leisure time without offensive or degrading remarks accompanying their public outings. ${ }^{20}$ When white women "stepped out" alone to participate in leisure activities, it only hurt them as individuals, and usually only when they behaved poorly. However, black women were rarely represented as individuals. Instead, their actions, conversations, and style were held up as representative features of the entire race. ${ }^{21}$ For these reasons, the leisure activities by black women and their demands for integrated public accommodations added to the litany of complaints whites

\footnotetext{
${ }^{19}$ For accounts of working-class women's leisure activities, see Kathy Peiss, Cheap Amusements: Working Women and Leisure in Turn-of-the-Century New York (Philadelphia, 1986); Nan Enstad, Ladies of Love, Girls of Adventure: Working Women, Popular Culture, and Labor Politics at the Turn of the Twentieth Century (New York, 1999); Cindy S. Aron, Working at Play: A History of Vacations in the United States, (New York, 1999).

${ }^{20}$ Timothy Gilfoyle, City of Eros: New York City, Prostitution, and the Commercialization of Sex, 17901920, (New York, 1994).

${ }^{21}$ For works that address the intersection of race, gender, and sex during the Gilded Age, see, Kali N. Gross, Colored Amazons: Crime, Violence, and the Black Women in the City of Brotherly Love, 1880-1910 (Durham, 2006); Kevin Mumford, Interzones: Black/White Sex Districts in Chicago and New York in the Early Twentieth Century, (New York, 1997); Mason Stokes: The Color of Sex: Whiteness, Heterosexuality, and the Fictions of White Supremacy (Durham, 2001); Gail Bederman, Manliness and Civilization: A Cultural History of Gender and Race in the United States, 1880-1917 (Chicago, 1995).
} 
publicized to defend the claim that blacks could not effectively participate in social life. Disgusted whites in Asbury Park recounted to the New York Times that as soon as the day's work was done, colored women "flocked by the hundreds to Bradley's beach, jostled for room on the plank walk, and said impudent things to persons who resented any effort at familiarity." The situation became worse, the individual noted after " 9 o'clock every evening," when "the negro waiters from the hotels would join them, and by giving full play to the spirits natural to the race, drive white persons back to the cottages and hotels long before Mr. Bradley's" curfew kicked in. Another white woman recounted to her husband an incident involving four black women who "jostled her off her seat." After protesting, she reported that one of the women exclaimed, "Oh, sho! 'Ts time fo' de white folks to moobe around' when we gits hyar." ${ }^{22}$ Reporting these incidents allowed whites to pile onto the already unending catalogue of crimes segregationists trotted out to justify segregation.

It was not just the replaying of black criminality that whites used, but also the goodwill gestures from local white officials that segregationists deployed to control the political debate. Correspondents to the Asbury Park Press defended Bradley as a "friend to the negro," who unlike many southern segregationists went "to the trouble and expense of fitting up grounds and bathing houses especially for them," and through generous financial contributions, contributed "\$1 per week to the supper of every" black church in the town. ${ }^{23}$ Echoing the sentiments of the Asbury Park Press, the New York Times reminded Asbury Park's black population that "Mr. Bradley has earnestly endeavored to solve the light and dark problem without giving offense to either shade of it," yet

\footnotetext{
${ }^{22}$ New York Times, July 19, 1885.

23 "That Vexatious Bathing Question," Asbury Park Press, July 14, 1890.
} 
continues to face "a large amount of vituperation because, as was aptly said, he undertook to separate the sheep from the goats at the bathing pavilions and on the boardwalks. ${ }^{, 24}$ In this early period of "separate but equal" at the Jersey shore, claims of white generosity served to limit and confine the charges of racism that black protesters consistently brought against Bradley and other white businessmen.

Through public reprisals, the laws of etiquette helped local authorities police public space without the interference of law enforcement personnel or courtroom legal judgments that white northerners believed were destructive to the social harmony many had come to expect in leisure and recreational venues. Instead, many beach towns officials relied on the physical stages and platforms themselves; they expected beaches, boardwalks, and viewing rooms to compel obedience. In tandem with the discursive boundaries outlined in the era's advice literature, these physical spaces contributed to the Victorian spectacle of public surveillance and self-reflection, allowing ordinary white citizens to maintain and manage self constraint, mediate disputes, and ensure the coherence of social boundaries by themselves.

Whites also advanced an aggressive defense of the rights of businessmen to deny African American access to recreational spaces and to control how they managed their time. In an editorial to the New York Times, a frequent visitor to Asbury Park complained that the "colored servant" who calls on Bradley to maintain "God's beach, depopulates it of every paying Caucasian," forcing Bradley "into the abyss of bankruptcy" and dooming his "hotels to tumble into a ruinous wreck of live slapboards and Indian red shingles." Another white visitor to Bradley's community, in what could have been adopted as the

\footnotetext{
${ }^{24}$ New York Times, July 20, 1890.
} 
resort's unofficial slogan, declared, "this is a white people's resort and it derives it support from white people."25

As a "white people's resort," white middle-class tourists marked black citizens who sat beside them in streetcars or mingled with them on the beaches and boardwalks as “evil." ${ }^{26}$ A white visitor from New York lamented to the Journal that in his excursion into Asbury Park, he confronted first hand the "evils" of black servants who served as waiters, cooks, and dishwashers in Bradley's resort community. The unidentified "Hotel Man" observed that on trains from New York and Philadelphia, as well as on the benches and seats at train depots, a sizable black faction seemed to "regard themselves as owners of all below the sky and are offensive and indecent." ${ }^{27}$ A reporter for the Philadelphia Inquirer similarly noted during the summer of 1893 that "never before" has the town "seem so overrun with the dark skinned race...It is easy to see," the reporter continued, "what an evil it is that hangs over Atlantic City." 28 The widespread use of the term "evil" by white citizens demonstrates the ways in which political contests over postwar social boundaries forced segregationist defenders to defend the moral economy of consumption; a critical component to the integrity and preservation of free labor ideology. ${ }^{29}$ Indeed, for many whites, the market itself had become a dangerous threat to property and propriety because of its occasional tendency to homogenize social relations and equalize access. In response, local authorities attempted to promote a version of the market defined less by

\footnotetext{
25 "Africa and Asbury Park," New York Times, July 7, 1885.

26 "Impudents," Daily Journal, July 7, 1885; "Two Distinct Factions," Shore Press, October 22, 1885.

26 "What Can Be Done?" Daily Journal, July 21, 1885.

${ }^{27}$ Daily Journal, July 21, 1885.

${ }^{28}$ Philadelphia Inquirer, July 23, 1893.

${ }^{29}$ Daniel Horowitz, The Morality of Spending: Attitudes Towards the Consumer in America, 1875-1940 (Chicago, 1992); John Joseph Goux, Symbolic Economies: After Marx and Freud (Ithaca, 1990); Stephen Mihm A Nation of Counterfeiters: Capitalists, Con Men, and the Making of the United States (Cambridge, 2007); Jocelyn Wills, "Respectable Mediocrity: The Everyday Life of an Ordinary American Striver, 1876-1890," Journal of Social History, 37 (2003): 323-349.
} 
profit, and instead, one that defended the interests of property owners from the claims and actions of consumer groups.

Alongside the routine use of the word "evil," white citizens also used more explicit economic language in their efforts to control the social behavior and consumption habits of black northerners. In editorials calling for the end of interracial space on the trains that carried tourists to the shore, whites insisted that blacks were "monopolists," "intruders," and "idle" paupers who sought to disguise their racial features for economic and social gain. ${ }^{30}$ The Philadelphia Inquirer complained, "both the boardwalk and Atlantic Avenue fairly swarm with them during bathing hours, like the fruit in a huckleberry pudding." ${ }^{31}$ In a July editorial titled 'Too Many Colored People," an Asbury Park visitor described the black "monopolists" who had become a "nuisance" to the resort's white tourists by demanding that unless "the number of black monopolists becomes smaller, we shall urge the proprietor of the beach to assert his right as owner and exclude them out."32

Such statements reflected the tendency of many segregationists to frame black consumer activity as fraudulent and politically disruptive. Throughout the Civil War period words like "contraband," "occupiers," and "intruders" entered the public's vocabulary to reveal the undefined place of African Americans in the public sphere and to mark them as saboteurs and social counterfeits whose ability to access consumer districts could only be assigned by whites. ${ }^{33}$ These practices were familiar strategies

\footnotetext{
30 "Intruders," Daily Journal, July 29, 1886; Stephen Crane, “Crowding Into Asbury Park,” New York Tribune, July 3, 1892.

${ }^{31}$ Ibid., July 23, 1893.

${ }^{32}$ Ibid., "Too Many Colored People."

${ }^{33}$ Kate Masur, "A Rare Phenomenon of Philological Vegetation": The Word "Contraband" and the Meanings of Emancipation in the United States," Journal of American History, 93.4 (March, 2007):1050-
} 
employed by antebellum white northerners, who during the 1840 s and 1850 s took pride in their ability to observe the workplace and personal habits of slaves and other industrial black workers. The practice of taking in the "spectacle" of black work during leisure hours allowed whites to delineate the divisions between work and play among racial groups, while highlighting the role that race and class played in constructing the economic boundaries of consumer culture. ${ }^{34}$ Yet in taking stock of the racial attitudes of white tourists, many white business owners and cultural tastemakers were less concerned with preserving white supremacy then they were in defending their new interpretation of free labor ideology. To white authorities confronting a new political coalition of consumer activists, ideas about free labor became less a defense of workers' rights to labor, than it did a convenient expansion of property rights. In tightening social restrictions on area boardwalks and beaches, local authorities embraced and marketed Jim Crow policies as the rational outcome of a market that was publicly sanctioned, voluntary, and consistent with a capitalist culture dedicated to the sanctity and preservation of private property.

To honor these new commitments, many business owners and resort promoters revised their previous motives for advertising the region's beach communities as progressive retreats. Mayor John Gardner of Atlantic City reflected that "in the early days, experiments had to be resorted to which nobody desired, because they were necessary to life." He noted further that "when the cheap excursions had to come, when questions about who came on them could not be raised" or when "other desperate expedients to raise the cash" were explored, that all "deplored it." As Gardner and others

1084; Alice Fahs, The Imagined Civil War: Popular Literature for the North and South, 1861-1865, (Chapel Hill, 2001).

${ }^{34}$ Aron, Working at Play, 136. 
who promoted Atlantic City in its "early days" noted, the delicate balance between giving "the people what they wanted" and the "hard business reality" of maintaining a profitable and popular summer resort exposed the public relations dilemma many resort owners faced under the regulations of the old common law tradition. ${ }^{35}$

Throughout the Civil War era, African Americans used the common law defense to pursue integration and gain legal admission to popular amusement venues. In hotels especially, proprietors faced a litany of requirements instructing them how to treat and care for paying customers. Local ordinances prohibited hotel proprietors from refusing service to paying customers who behaved themselves, and also held them responsible for providing meals and looking after the belongings of their guests. ${ }^{36}$ Litigators justified these restrictive measures by arguing that in taking care of the public welfare of travelers, proprietors were maintaining the peace of local communities and ensuring that confidence men and other illegitimate swindlers would not cheat decent, well-paying customers.

Throughout the antebellum era, a financially restrictive leisure marketplace that made beach resorts and other popular amusement venues too expensive for working-class Americans also aided the common law. In the aftermath of Reconstruction, however, a new generation of white and black tourists flooded northern beach towns for the first time, violating — in the minds of white elites — conventional social tastes and respectable

\footnotetext{
${ }^{35}$ Alfred M. Heston, Absegami: Annals of Eyren Haven and Atlantic City, 1609 to 1904, 2 vols, (Camden, NJ, 1904), 327.

${ }^{36}$ Tunis Campbell, Hotel Keepers, Head Waiters, and Housekeepers' Guide, (Boston, 1848); S.A. Frost, The Laws and By-Laws of American Society (New York, 1869); R. Vashon Rogers, The Law of Hotel Life of the Rights and Wrongs of Host and Guest, (San Francisco, 1879); Samuel H. Wandell, The Law of Inns, Hotels, and Boarding Houses: A Treatise Upon the Relation of Host and Guest (Rochester, NY: 1888); John Tellman, The Practical Hotel Steward, (Chicago, 1900); A.K. Sandoval Strauss, "Travelers, Strangers, and Jim Crow: Law, Public Accomodations, and Civil Rights in America, Law and History Review, 23.1 (Spring 2005), 62-65; Gregory J. Service, Hotel-Motel Law: A Primer on Innkeeper Liability (Springfield, Illinois, 1983).
} 
etiquette. For these reasons white business owners maintained their suspicions of national and state courts' willingness to defend social customs and justify segregation. Unable to defend their property rights against black protestors in particular, proprietors of public accommodations became increasingly subjected to local fines, disruptions of service, and jail time for refusing to obey common law rulings. ${ }^{37}$ As a result, African Americans successfully desegregated streetcars and other common carriers in New York City, Philadelphia, and Washington D.C. ${ }^{38}$

The segregation debate at the Jersey Shore, however, allowed whites to reconfigure local understandings of the common law. In Asbury Park, James Bradley's position as both proprietor and mayor blurred the lines between public and private upon which the common law defense rested. John Coffin, one of Bradley's advisors, explained Bradley's unique position in defending segregation. "To reach the bathing pavilions or the bath houses or to walk on the wide stretch of hard sand where the billow came tumbling in," Coffin instructed, "visitors must encroach on the territory of James A. Bradley, who bought property here when it was a barren waste." Yet Coffin noted that Bradley did not restrict his property to his own private affairs. Instead, he "built clusters of little houses, pushed poles beneath the sand, made comfortable pavilions for people to sit and enjoy the salt breezes, and laid down a solid plank walk wider than the average street pavement. ${ }^{39}$ Coffin's narrative of Asbury Park's humble origins was intended to

\footnotetext{
${ }^{37}$ For examinations on the Common law's influence upon public accommodations and popular amusement venues see, William Novak: The People's Welfare: Law and Regulation in Nineteenth Century America (Chapel Hill, 1996); Sandoval-Strausz, "Travelers, Strangers, and Jim Crow," Barbara Welke, Law and Borders of Belonging in the Long Nineteenth Century United States (Cambridge, 2010); Rebecca Scott, "Public Rights, Social Equality, and the Conceptual Roots of the Plessy Challenge," Michigan Law Review, 106.777 (March, 2008):777-804.

${ }^{38}$ Ibid., Kelly, Right to Ride; Judith Giesberg, Army at Home: Women and the Civil War on the Northern Home Front, (Chapel Hill, 2009).

${ }^{39}$ New York Times, July 19, 1885.
} 
dispel local blacks' complaints that beach towns were the public domain. In advertising Asbury Park to prospective tourists, Bradley consistently remarked that his town did not fall squarely within either category, but was instead his property to do as he pleased. Like other Gilded Age resorts, which sought to relinquish the public's demands on its proprietors, Bradley called on northern "guests" to "come make yourself at home." ${ }^{, 40}$ The choice of the words "guests" and "home" by Bradley was supposed to signal to potential civil rights protestors that Asbury Park was an apolitical sphere, a resort that responded only to the desires and tastes of its proprietor, in which tourists were expected to act as if they had entered someone's home.

Asbury Park was not alone in circumnavigating the common law. Many cities throughout the late-nineteenth century found creative ways to violate local civil rights statutes by passing restrictive ordinances that permitted proprietors to eject any person found to be creating "disturbances" in hotels, theatres, or restaurants. ${ }^{41}$ To defend the restrictions, whites defined "disturbances" in expansive ways. This could include a drunk or thieving patron, or it could include anyone whose actions violated agreed upon decorum or social tastes. Part of the laws of etiquette upon which "respectable people" agreed was the idea that politics should be kept out of polite conversation and leisure spaces. African Americans who publicly demonstrated in favor of integration were cast as illegitimate social guests who ruined the vacation experiences for others by violating standardized rules of etiquette. As such, white proprietors declared that they were within their rights as arbiters of the public's welfare to refuse admission and uphold segregation.

\footnotetext{
${ }^{40} \mathrm{Ibid}$.

41 “The Civil Rights Act,” San Francisco Bulletin, March 8, 1875.
} 
To defend the restrictions against those who pressed for their rights as consumers, segregationists maintained that similar impediments to consumer rights were already established in theatres, which long held to the established practice of denying ticket-goers admission to shows with tickets purchased by someone else. However, most segregationists maintained that a blanket complaint of consumers' rights was beside the point of the Civil Rights Act. "Educated colored men will not force an offensive interpretation," one innkeeper noted, and "coarse ones will not be sustained by the sentiment of the people, save to protect them against discrimination in public conveyances. ${ }^{\not 2}$ Thus, while the right of consumers should be respected, whites insisted that it was not an absolute and certainly did not trump the rights of proprietors. As one advice book advised, northern blacks citizens needed to understand that true respectability was 'contained in the homely maxim, 'Mind Your Own Business,' which means by a pretty evident implication, that you are to let you neighbor's business alone. ${ }^{43}$

Benjamin Butler, a vigorous champion of blacks' civil rights throughout the Civil War era, exemplified this view when he upheld the common law's oath to defend the rights of African Americans, but stopped short of promoting complete integration. Interviewed shortly after the passage of the 1875 Civil Rights Act, Butler reiterated that the laws of etiquette trumped traditional interpretations of the common law and modern notions of consumer rights. Asked about the rights of blacks to enjoy popular amusements alongside whites, Butler noted that while he was "willing to concede" that

\footnotetext{
${ }^{42}$ Ibid.

${ }^{43}$ Quoted in Michael McGerr, A Fierce Discontent: The Rise and Fall of the Progressive Movement in America (New York, 2003), 209. See also, Cecil B. Hartley, The Gentleman's Book of Etiquette and Manual of Politeness, (Boston, 1860); George Winfred Hervey, The Principles of Courtesy: With Hints and Observations on Manners and Habits, (New York, 1852).
} 
he was a "friend to the negro," he was also committed in his belief that "the white race may have at least this one superior privilege to the colored man." Like those who justified segregated leisure elsewhere by noting that respectable blacks would never place civil rights above the laws of etiquette, Butler argued that whites who ejected blacks from saloons and other leisure venues would be doing the "colored man no greater kindness." With respect to the common law, Butler refused to acknowledge that any Civil Rights act was a promotion of unregulated liberty. "All ideas that the civil rights bill," Butler explained, "allows the colored man to force himself into any man's hop, or into any man's private house, or into any eating house or establishment other than those I have named," is not supported by the law. Indeed, he justified the rights of "private business and private parties" to eject any African American consumer attempting to interfere with the rights of proprietors since "it is beneath the dignity of any colored man to do so." 45 Like the expansive definition of "disturbances" that whites created to justify segregation, politicians like Butler, and local officials at the Jersey shore used a liberal understanding of "force" to deny African Americans admission to leisure venues. When whites talked about "force" they were not only taking about maintaining the peace from the illegal activities of conventional criminals, but were also conjuring up an implied threat to privacy, property, and propriety.

Part of the difficulty both whites and blacks had in defending the common law was that it made a tenuous case for both sides. While many African Americans successfully applied the common law in protesting segregation, white northerners in the 1880s and 1890s also retained faith in the common law tradition by evoking its private

\footnotetext{
44 "Butler on Civil Rights," The Inter Ocean, March 23, 1875; “Enforcement Guaranteed," The Sunday Times (Chicago), March 21, 1875.

${ }^{45}$ Ibid.
} 
property qualifications. For example, while proprietors were held responsible for the well-being of travelers, the same rights did not apply to local residents. Community officials were routinely notified of out-of-town guests so that appropriate steps could be taken to remove unwanted or unsightly locals. In State v. Wilby, the Delaware Supreme Court upheld these decisions by allowing proprietors flexibility in defining "disturbances" and "force." Although the court reaffirmed the right of admission to "all persons," it offered one important caveat. Any guest, the court declared, "has a right to remain there so long as he behaves himself peaceably and properly, he paying for the entertainment." ${ }^{, 46}$ These exceptions aided segregationists by legitimizing two of the most important components that Jersey shore proprietors drafted in justifying Jim Crow laws. By permitting the refusal of service based on behavior, whites were free to invoke the laws of etiquette that universally marked African Americans as unfit for social life. In addition, the court ruled that integration was only absolute for paying customers, a condition that excluded most blacks, since the majority of African Americans enjoyed their leisure time in venues that were free of charge.

In most northern settings, the right to access beaches, boardwalks, and other free leisure venues would have allowed African Americans legal options, since the common law denoted differences between public and private dwellings, and those spaces generally fell within the domain of public spaces. Yet as James Bradley's defense indicated, the unique make-up of many Jersey shore beach towns complicated the definition of public space. Bradley routinely pointed out that the borough of Asbury Park stopped short of the boardwalks and beaches, allowing him to choose whether he wanted to charge admission to visitors for right to access those areas.

\footnotetext{
${ }^{46}$ State v. Whitby, 5 Har. (Del.) 494 (1854).
} 
The flexibility that beaches, boardwalks, and bathing pavilions provided segregationists highlights the problematic functions of the common law defense for integrationists. Even the most ardent common law proponents and advocates of integration believed that social space could not be regulated by the state or infringed upon by activist courts. Many leading legal advocates had made this clear throughout the nineteenth century. Charles Goorich, for example, explained that any legal statute had to conform to the "habits of the people." Horace Wood echoed these sentiments in $A$ Practical Treatise on the Law of Nuisances. Of importance for Jersey shore segregationists were Wood's ideas about the limits of liberty and the sanctity of property. "No man is at liberty," Wood declared, "to use his own without any reference to the health, comfort, or reasonable enjoyment to like public or private rights by others. ${ }^{, 47}$ By defining personal liberty in relationship to the preservation and health of the community, Wood reassured officials at the Jersey shore that local notices and practices did not conflict with the state's anti-segregation laws. Because the common law rested on a restrained notion of liberty and individual rights, segregationists remained committed to the common law since it allowed them to counter the civil rights appeals of black protesters.

Wood's interpretation of the common law also offered segregationists a way around African Americans claims for consumer rights. By arguing that a person's liberty could not endanger or sacrifice the health and welfare of the community, he reaffirmed key components of a service industry's responsibilities. Both Asbury Park and Atlantic City, segregationists maintained, were not typical communities. White business owners were obligated to provide a service to high paying customers, which required that they

${ }^{47}$ Horace G. Wood, A Practical Treatise on the Law of Nuisances, 2 d ed. (Albany, NY, 1883) 21. 
sometimes pander to the interests and opinions of more valued guests. Activities by

African American consumers, which endangered the financial solvency of that enterprise by dissuading white tourists to frequent their resorts, justified the enactment of certain regulations.

As segregationist defenders at the Jersey shore articulated, a defense of privacy and property denoted that African Americans could not rush public sentiment or speed up the pace of racial feelings. To do so would violate the core philosophy of late-nineteenth century liberalism, which emphasized the primacy of the individual as the sole arbiter of his actions. The widespread acceptance of beach towns as anti-political spaces exacerbated and complicated these beliefs. Because the leading political and legal figures were also the region's captains of industry, the entire notion of individual rights was highly fluid. ${ }^{48}$ While Reconstruction politics enshrined individual rights in a host of political and legal documents throughout the postwar period, northern whites retained a contradictory approach to maintaining the peace in northern beach resorts. Indeed, the great irony of Jim Crow at the Jersey shore was that the same language used to legitimize individualism was the same one used to stifle it. In the end this became the double bind of the common law and the Gilded Age marketplace. African Americans could look to each as appropriate templates for integration, while segregationists could manipulate and recreate certain features of both to justify Jim Crow.

\footnotetext{
${ }^{48}$ In several critical ways, northern leisure venues approached the law and individualism in similar ways as southerners did. Ideas about the law, justice, and freedom in the nineteenth century South were radically particular, often conforming and responding to the interests and values of a specific community and locale. As Laura Edwards writes, southerners applied the law "as their modality of rule, a system that responded to their problems and could express their own conceptions of justice." Laura Edwards, The People and Their Peace: Legal Culture and the Transformation of Inequality in the Post-Revolutionary South (Chapel Hill, 2009), 79.
} 
Throughout the late 1880s and early 1890s, white officials in Asbury Park and Atlantic City would apply the common law to justifying segregation. After officially barring African Americans from the region's beaches, boardwalks, and bathing facilities, white property owners and local officials appealed to a reconfigured common law tradition that linked the public welfare with a defense of private property and economic prosperity. James Bradley explained that African Americans were denied the same rights accorded to white tourists, because as both "colored citizens" and as "servants," their presence decreased the attraction to white visitors and threatened the economic value of the community. ${ }^{49}$ In a personal letter to the Daily Journal, Bradley explained that although racial prejudice had declined in the years since the Civil War, the presence of black tourists still provoked anxieties that would need to be worked out through public opinion, rather than through legal rulings. "There are undoubtedly many whites," Bradley explained, "who object to the mere presence even of well behaved and well conducted colored people" desiring the same leisure and commercial spaces as white tourists. ${ }^{50} \mathrm{~A}$ frequent visitor to Asbury Park explained in an editorial to the Daily Journal that "we allow them to vote, to have full standing of the law, but when it comes to social intermingling then we object most seriously and emphatically."51

When Atlantic City proprietors began posting segregation ordinances in its hotels, restaurants, and other venues throughout the late-nineteenth century, local officials explained the need to revise the common law. "Until recently," one proprietor declared, "hotel men were disinclined to force the issue, which to them would look like

\footnotetext{
${ }^{49}$ Ibid., "Intruders."

50 “'Letter from Wiesbaden,” Daily Journal, August 17, 1886.

${ }^{51}$ Ibid., "Too Many Colored People."
} 
discrimination." Yet "when it reached the issue of dollars, the hotel men acted." ${ }^{, 52}$ Signs posted in the employee sections of restaurants and hotels notified black workers that "we therefore require that you, our colored employees, and your family and friends, not to bathe or lounge in front of our respective properties." In an attempt to preempt claims from black workers that the new statutes were in violation of their rights or reflected the growing racist sentiments of white northerners, the notice concluded its instructions by reiterating: "feeling sure that you will appreciate the appeal in the spirit in which it is made and that its observance will benefit both yourselves and ourselves." ${ }^{, 53}$

The segregationist appeals to the public's welfare revealed the defensive state of free labor ideology in an age of mass entertainment and the new discourse of consumer rights. While white elites heralded the independent worker "on the make" as the embodiment of the free labor ethic, they also sought to use the market to restrain those undesirable citizens whose personal ambitions and consumption habits threatened to undermine the social profile of northern beach resorts. ${ }^{54}$ James Bradley explained that, "In order that those people may earn their living it is necessary," that only citizens of the "Caucasian race shall find Asbury Park attractive." "The question of color or rights," he informed, was not "to enter into consideration." ${ }^{, 55}$ John Coffin, who edited Asbury Park’s Daily Journal, responded to those who criticized the paper for inflaming racial tension by insisting, "perhaps people who have not been troubled with such a disagreeable monopolization of both private and public places by Negroes will think our action harsh

\footnotetext{
${ }^{52}$ Atlantic City Gazette, June 29, 1906, 4.

${ }_{53}^{53}$ Atlantic City Review, June 26, 1906, 1.

${ }^{54}$ Michael O'Malley, "Rags, Blacking, and Paper Soldiers, Money and Race in the Civil War," in eds. James W. Cook, The Cultural Turn in U.S. History: Past, Present, and Future (Chicago, 2009); Brian P. Luskey, On the Make: Clerks and the Quest for Capital in Nineteenth-Century America (New York, 2010). ${ }^{55}$ Ibid., "Intruders."
} 
and unjustifiable." Yet Coffin warned that "something must be done or we cannot induce visitors to come here." 56

Mirroring Coffin's justifications, the northern press often rushed to Bradley's aid, explaining that economic realities, and not personal prejudice, justified Asbury Park's new segregation laws. "When he forms the opinion that a particular line of conduct on the part of a particular class of people is injuring the place," the New York Times declared, "it must be supposed that this is his opinion as a man of business, and has nothing to do with his personal sentiments. ${ }^{, 57}$ During the 1880 s and 1890 s, white northerners thus came to see two types of African Americans in places of leisure: those who worked diligently for wages without laying claim to consumer rights, and those who threatened the integral relationship between the social order and the market economy by refusing to yield to the judgments of the market.

The comments by Bradley and his supporters reveal key distinctions between how blacks and whites interpreted the role public opinion played in regulating market behavior. While many officials tried to ignore the racial comments posted on the editorial pages of Asbury Park's periodicals, they could not always prevent members of the northern press and ordinary citizens from admitting that racism was the primary catalyst for the appearance of Jim Crow laws in the region. The New York Times confessed that the "majority of the white people" in Asbury Park "do not conceal the fact that they are pleased" with the new laws. Yet, for the most part, white northerners reaffirmed a discontinuous white supremacy. "There is no doubt," a visitor remarked to a reporter, that the calls for segregation "only reached its present outspoken vehemence after much

\footnotetext{
56 "Drawing the Color Line: Negroes Who Offend the Residents of Asbury Park," New York Times, July $19,1885$.

57 “Africa and Asbury Park,” New York Times, July 7, 1887.
} 
forbearance and long suffering. Matters have simply gotten a pitch," the individual insisted, "where the white people must sit quietly down and let the negroes run the place," or act decisively in enforcing stricter segregation ordinances. ${ }^{58}$

Other segregationist defenders, however, denied that public sentiment was against black recreation. A group of defensive white patrons resented the claims by Bradley and other local officials that the racism of white tourists ensured the justification for segregation, a notion that they believed sidetracked the debate from matters of economic philosophy. Drafting a letter to the The Sun, the individuals exclaimed that "we except to those portions of the article which declare that Mr. Bradley does not care to draw the color line, but public sentiment insists in drawing it for him, and that hotel keepers might almost as well admit a small-pox patient as a negro, and that white people refuse to go where they will be brought into contact with large numbers of negroes." Instead, the individuals noted that the liberal spirit of Reconstruction had ensured just the opposite sentiments. "Was it not a public sentiment," the group asked, "which was brought about by the very general feeling that the negro was justly and honestly entitled to his citizenship and all that it entailed, and should have it?" To this question they answered, "If the color line was then drawn, it was drawn in the interest of justice and in consonance with what I would believe was an American idea of fair play." 59

Like the racially coded language of "common sense," "disturbances," "force," and "nuisance," whites often resorted to the term "fair play" to denote segregation's marketbased origins. "It is not a race war," an editorial in New York's The Sun declared. Instead, it was "purely a matter of business policy," conducted for the "practical purpose

\footnotetext{
${ }^{58}$ New York Times, July 19, 1885.

59 "Race Prejudice," The Sun (NY), July 17, 1887.
} 
of making money." Another individual interviewed for the article, agreed, exclaiming that if "Mr. Bradley could make Asbury Park more profitable by turning it into a negro resort exclusively, we have no doubt he would make the change. The color of his patrons' money, not the color of their faces, is what he is interested in." ${ }^{60}$ To white tourists tired of explaining themselves to white liberals and black activists, discussions of race were irrelevant to the segregation debate. As a matter of sound business policy, segregation was legal, legitimate, and necessary to ensure basic market principles, without which the system would cease to remain solvent.

The arguments over the uses and role of public opinion illustrate conflicting versions of the market's social responsibilities. African Americans insisted that socialand not just political - equality was a precondition for an unregulated marketplace. Whites, however, insisted that political constraints like equality imposed their own set of regulations upon the market that denied white consumers and producers free choice. "Social relations," one Jersey shore business owner maintained, "are entirely voluntary. They cannot be controlled by force." In denouncing the claims of African Americans that equality must predate an invisible hand, the businessman instructed, "the negroes are free politically. They have the same legal rights as the rest of the people, and the same social rights. Social equality, on the other hand, is an impractical request in a democratic and market-based society. Neither a white man or a Negro can compel people to like and associate with him." Segregation was thus legitimate, others noted, because it was not a function of the law, but rather a function of social tastes that resided outside the realm of government or the courts. "If white people at Asbury Park objected to the association of

\footnotetext{
60 "The Colored People at Asbury Park," The Sun (NY), August 3, 1893.
} 
the negroes with them in the pavilions," another white visitor to the beach town remarked, "no law can prevent them from expressing the objection.",61

In defending segregation as a policy that promoted free expression and social choice, local authorities argued that the market was functioning properly since it allowed black citizens the freedom to pursue other recreational options if they encountered choices of amusement or consumption that violated their tastes. African Americans could either accept the free expression of opinions by following the rules of a given social environment, or they could choose to frequent a more hospitable public or commercial area. If neither of these choices were acceptable, whites provided a third alternative, informing African Americans that if they desired integrated and interracial leisure options, that they could do so only by preparing themselves to better meet the tastes and preferences of prejudiced whites. A frequent visitor to Asbury Park explained, "the best advice their preachers can give them is to keep quiet and improve himself or herself individually, so that they will be more valuable to industry." Yet rather than follow this advice, the individual noted that African Americans were letting their "restlessness under social discrimination interfere with their practical prosperity.... They cannot change the feeling by fighting against it any more than they can change the color of their skin by washing it.",62

Justifying segregation as a defense of political economy, rather than of race entailed a careful manipulation of cultural and legal ideologies. By making the choice of integration and segregation entirely one for blacks, whites challenged African Americans to violate both the laws of etiquette and the laws of the marketplace-a tactic that would

${ }^{61}$ The Sun (NY), August 4, 1893.

${ }^{62}$ Ibid. 
allow segregationist defenders to justify their policies as just, rationale, and inoffensive. For white business owners and local officials, this narrative was a crucial prerequisite for maintaining the appearance of a color-blind public sphere. If blacks conformed to the standardized modes of behavior drafted by whites, the public language of Jim Crow signs could be less offensive, allowing future generations of liberal policymakers to manage racial change by defending market-based solutions. This strategy still left white business owners exposed to charges of discrimination from African Americans, but it prevented local officials from having to correct these flaws through legal or political means. 


\section{Chapter 4: Boycotting Jim Crow, 1890-1920}

In July 1911, the Crisis proudly announced to black tourists the opening of the Dale Hotel in Cape May, NJ. Constructed with the financial backing of prominent businessman and popular community leader, Edward Dale, the Jersey shore's newest hotel symbolized the long-fought efforts of local blacks to counter the disparaging attacks on black leisure and to fill the void of respectable tourist accommodations for out-oftown guests. Recognizing that black consumers were often turned away from many of the region's respectable hotels and confined to ill-kept and cramped accommodations, the Crisis proudly exclaimed that the Dale Hotel was the "finest and most complete hostelry in the United States for the accommodation of our race." Boasting magnificent views, modern amenities, and convenient access to the seashore, the Dale hotel—and other similar ventures — became proud symbols for African American tourists and political models for blacks entrepreneurial skill and responsible recreation. ${ }^{1}$

In the mid-1890s northern blacks faced important decisions in their quest for recreation and consumption. Should they continue to fight segregationists for admission to area leisure spaces or should they begin to finance their own recreational venues? Was black behavior or white racism to blame for segregation? Did dance halls, gambling dens, and pool halls constitute legitimate leisure options? In the 1880 s, the preference for civil rights activism and the lack of capital prevented many African Americans from developing an entertainment and leisure district of their own. By the turn of the century, however, many local leaders reconsidered their approach to segregation by calling on

\footnotetext{
1 "Hotel Dale" (Advertisement), The Crisis, July 1911.
} 
black workers and tourists to boycott establishments and public venues that denied them entry and instead to "spend your money among your own people."2

The decision to abandon the Jersey Shore's white marketplaces underscored the evolving attitudes blacks held toward integration in the face of mounting Jim Crow boundaries. Although integrated leisure remained the preference of many black workingclass residents, others began to reevaluate their approach to segregation and white racism. The Philadelphia Call issued a warning to northern black leaders, urging them to rethink civil rights demonstrations in favor of economic development. Remarking that it was "strange that the colored people of the North have not taken hold of this color question in a practical way," the paper instructed potential black entrepreneurs that there was "money as well as dignity in the scheme if properly managed." Recognizing the urgent need for economic expansion and moral reconstruction, many black ministers and entrepreneurs argued that the public image and financial solvency of the black community rested on whether or not African Americans could build lucrative leisure ventures capable of providing affordable, safe, and popular recreational options to black consumers.

Black-owned hotels and other "respectable" leisure venues not only answered the community's economic challenge, but also served to counter the damaging popular culture image of blacks' leisure that segregationists employed to legitimize and sustain

\footnotetext{
${ }^{2}$ Colored American Magazine, "Atlantic City," October, 1906. For studies that detail the history of Jim Crow boycotts during the early 1900s, see esp. David E. Alsobrook, "The Mobile Boycott of 1902: African American Protest or Capitulation," Alabama Review (April 2003): 83-103; David S. Bogen, "Precursors to Rosa Parks: Maryland Transportation Cases between the Civil War and the Beginning of WWI," Maryland Law Review 63 (2004): 721-751; Cheryl Greenberg, "Don't Buy Where You Can't Work," in Lawrence Glickman, eds, Consumer Society in American History: A Reader, (Ithaca, 1999): 241-276; Blair M. Kelly, Right to Ride: Streetcar Boycotts and African American Citizenship in the Era of Plessy vs. Ferguson (Chapel Hill, 2010); Meier and Rudwick, "The Boycott against Jim Crow streetcars in the South;" Andor Skotnes, " 'Buy Where You Can Work: Boycotting for Jobs in African American Baltimore, 1933-1944," Journal of Social History 27 (1994): 735-762; Andrew Wiese, Places of Their Own: African American Suburbanization in the Twentieth Century (Chicago, 2004).

3 “An Asbury Park of Their Own," Philadelphia Call, June 29, 1887.
} 
Jim Crow throughout the late-nineteenth century. As black entrepreneurs observed, the degradation of blacks' leisure and public denunciations of black morality were not only reserved for civil rights demonstrations or limited to the pre-Jim Crow era. Beginning in the mid-1890s, black leisure districts became the focus of voyeuristic "slummers" as well as the targets of law enforcement raiders who singled out black-owned vice venues to publicize their aggressive response to bootlegging, illegal gambling, and prostitution. ${ }^{4}$ To many black northerners, the completion of the Dale Hotel represented the political urgency of protecting their claims to free consumption through socially respectable capitalist ventures.

The history of these entrepreneurial and political efforts rebukes the static narrative of accommodationism that often pervades the secondary literature. According to conventional historiographical wisdom, northern blacks who refused to push for integration did so to preserve their class status, gain the social acceptance of disapproving whites, or to protect their individual financial ventures. As the story goes, these were individuals whose privileged upbringing allowed them the ease of "moving with the times;" "black aristocrats" who developed a class-conscious "settler" outlook that made them weary of working-class migrants who threatened to undermine the race's hard-

\footnotetext{
${ }^{4}$ For works detailing the political discourse of black criminality and policing tactics undertaken in turn-ofthe-century northern black urban communities, see Marcy S. Sacks, “'To Show Who Was in Charge': Police Repression of New York City's Black Population at the Turn of the Twentieth Century," Journal of Urban History 31 (September 2005): 799-819; Khalil G. Muhammad, The Condemnation of Blackness: Ideas About Race and Crime in the Making of Modern Urban America (Cambridge, 2010); Kevin Mumford: Interzones: Black/White Sex Districts in Chicago and New York in the Early Twentieth Century (New York, 1997). The ways in which segregationists worked to uncut black coastal property in the Jim Crow South is explored in a number of recently published works. See esp. Andrew Kahrl: The Land Was Ours: African American Beaches from Jim Crow to the Sunbelt South (Cambridge, 2012); Nathan D.B. Connolly, "By Eminent Domain: Race and Capital in the Building of An American South Florida" (Ph.D. diss., University of Michigan, 2008); Michael N. Danielson, Profits and Politics in Paradise (Columbia, SC, 1995); and Russ Rymer, American Beach: A Saga of Race, Wealth, and Memory (New York, 1998).
} 
fought victories. ${ }^{5}$ To be sure, many black moralists at the Jersey shore held these views, were outspoken with their displeasure of unruly black pleasure seekers, and at times questioned the practicality and sustainability of civil rights. Yet while clearly defined class tensions pervaded internal discussions over segregation, this narrow interpretive framework ignores the intricacies of intraracial leisure efforts undertaken by black entrepreneurs to boycott segregation by building an independent black leisure industry. Individual and collective campaigns for intraracial leisure by many northern African Americans help to show that the internal segregation debate was not one that can be defined solely by issues of class and conflicts over individual morality. Instead, intraracial political discussions over leisure options revealed a multifaceted and at times politically contentious conversation over consumer protests and cultural independence. Throughout the early Jim Crow era, black entrepreneurs who risked their capital in the pursuit of personal wealth and racial uplift by boycotting white establishments proved as vital to the northern black freedom struggle for free consumption as civil rights demonstrators who fought segregationists through direct political action in the 1880 s and early 1890 s. $^{6}$

\footnotetext{
${ }^{5}$ Many prominent works have long noted the importance of class dimensions in framing political debates in turn-of-the-century black communities. See, Willard B. Gatewood, Aristocrats of Color: The Black Elite, 1880-1920 (Fayetteville, 2000); Kevin Gaines, Uplifting the Race: Black Leadership, Politics and Culture in the Twentieth Century, (Chapel Hill, 1996); Glenda Gilmore, Gender and Jim Crow: Women and the Politics of White Supremacy in North Carolina, 1896-1920 (Chapel Hill, 1996); Joe R. Fergin, Living with Racism: The Black Middle-Class Experience (Boston, 1994); Mark S. Foster, " 'In the Face of Jim Crow': Prosperous Blacks and Vacations, Travel, and Outdoor Leisure, 1890-1945," Journal of Negro History 84 (Spring 1999); Lawrence Otis Graham: Our Kind of People: Inside America's Black Upper Class (New York, 1999); Andrew W. Kahrl, “" 'The Slightest Semblance of Unruliness': Steamboat Excursions, Pleasure Resorts, and the Emergence of Segregation Culture on the Potomac River," The Journal of American History 94.4 (March 2008); August Meier and Elliot Rudwick, "The Boycott Movement against Jim Crow Streetcars in the South, 1900-1906," in Along the Color Line: Explorations in the Black Experience (Urbana, 1976): 267-89; and Michele Mitchel, Righteous Propagation: African Americans and the Politics of Racial Destiny after Reconstruction (Chapel Hill, 2004).

${ }^{6}$ John H. Burrows, The Necessity of a Myth: A History of the National Negro Business League, 1900-1945 (Auburn, AL, 1988); Horace Cayton and St. Clair Drake, Black Metropolis: A Study of Negro Life in a
} 
To promote and sustain a black leisure industry, black business owners negotiated land deals with skeptical developers, sought out fundraising dollars to promote their ventures, fought against prevailing cultural norms that denied the prospect of black entrepreneurial skill, and fought to keep away the long arm of law enforcement and scheming whites who sought to belittle, shut down, and exploit their enterprises. In their efforts to remake the black community by boycotting white-owned leisure establishments, these men and women became consumer advocates of a different sort, working tirelessly to adapt to changing political realities in the hopes of shielding black workers and patrons from the damaging moral and financial effects of Jim Crow's reach.

Throughout the late-nineteenth century, northern race leaders seldom agreed on how African Americans should spent their free time. In 1897 W.E.B. DuBois declared that the "manner, method, and extent of a people's recreation is of vast importance to their welfare." ${ }^{, 7}$ Yet even DuBois offered few specific plans regarding how blacks should promote entertainment and consumption without sacrificing traditional ideas about racial uplift and political economy. To many black political thinkers, the traditional notion that consumption of even "cheap amusements" led to the long-term impoverishment of the race prevented many from developing a comprehensive and modern civil rights plan for

Northern City, 2 vols. (New York, 1945); Walter D. Greason, The Path to Freedom: Black Families in New Jersey, (New York, 2010): 105-124; Kenneth Marvin Hamilton, Black Towns and Profit: Promotion and Development in the Trans-Appalachian West, 1877-1915 (Urbana, 1991); Sharon Ann Holt, Making Freedom Pay: North Carolina Freedpeople Working for Themselves, 1865-1900 (Athens, 2000); Juliet E.K. Walker, The History of Black Business in America: Capitalism, Race, Entrepreneurship (New York, 1988); and Robert Weems, Jr., Desegregating the Dollar: African American Consumerism in the Twentieth Century (New York, 1998).

${ }^{7}$ W.E.B Dubois, “The Problem of Amusement," Southern Workman 26 (September 1897). Du Bois would later speak more extensively about the problems of public amusements and the exclusionary practices enacted against black pleasure seekers. See, DuBois, "The Color Problem of Summer," Crisis (July 1929); and Pittsburgh Courier, "About Vacations," September 18, 1937. 
meeting the challenge of segregated leisure. In the antebellum North, the black press spoke openly about the "cruelty of idleness" and the lack of respectable outlets for spending one's leisure time. In 1837, the Colored American admonished its readers for "always finding some excuse for killing that precious time," which could be better spent, in the "cultivation of our minds," by building libraries, frequenting reading rooms, and attending "useful lectures." ${ }^{8}$ For conservative black leaders concerned with how the examples of black workers affected racial progress, the "pernicious example of idleness" presented a "national burden to others" interested in discrediting racist imagery and Jim Crow policies that denied African Americans equal access to civic and consumer life. ${ }^{9}$

To set an appropriate example, many members of the northern black elite retreated from public leisure venues. They spent their summers in peripheral and secluded spots at Saratoga Springs and Newport. In the "off-season," many families and well-to-do individuals entertained guests in private residences, turning parlors, verandas, and gardens into inclusive leisure outings. These class-based enclaves dominated preCivil War black leisure life. ${ }^{10}$ Even after the war, many black consumers who desired to participate in the Gilded Age marketplace chose to do so through the anonymity of mailorder catalogs. ${ }^{11}$ Yet the growing popularity of commercial leisure during the latenineteenth century compounded the moral and economic dilemma that race leaders believed impeded national progress. Throughout the Gilded Age, regional journalists, community pastors, and civic activists frequently admonished working-class blacks for their reckless behavior in area resorts, amusement parks, and street-corners. Challenging

\footnotetext{
8 "Leisure Hours," Colored American, March 18, 1837.

9 "The Cruelty of Idleness," Colored American, February 7, 1838.

${ }^{10}$ Gatewood, Aristocrats of Color.

${ }^{11}$ Lawrence Glickman, Buying Power: A History of Consumer Activism in America (Chicago, 2009); Greenberg, "Don't Buy Where You Can't Work;" and Weems, Desegregating the Dollar.
} 
black workers to "think well of yourself," they called for a national referendum on "good manners" and the eradication of the "noisy and dirty negro." ${ }^{12}$ By the turn-of-the-century, scores of advice literature outlined appropriate public decorum and scrutinized attendance at interracial social clubs, gambling dens, and prostitution houses. ${ }^{13}$

Despite the proliferation of these advice manuals, members of the black elite never completely surrendered their claim to public leisure. Throughout the postwar period, the progressive rhetoric of the Jersey shore's early promotional strategies and evolving attitudes toward mass consumption motivated many to reclaim a space in public life. Joining other well-to-do black vacationers for extended summer stays at the Jersey shore, they found themselves in competition for public space with members of the black middle and working classes, whose own class ambitions conflicted with the standard protocol of their social superiors. Compounding these long-standing class tensions was the advent of the excursion trip. A product of modern transportation, excursions were often financed and popularized by church groups and other fraternal affiliations. A truly democratic creation, the excursions placed well-to-do black professionals on board with the North's working-class tourists. Yet once the trains and boats that ferried blacks to their destinations docked, those on board quickly separated. Well-to-do blacks took up residence in cottages and sought out peaceful refuge on secluded stretches of sand, often out of white tourists' sight. Many working-class excursionists, on the other hand, spent time in the more public sections of town. To the disappointment of black elites and white

\footnotetext{
${ }^{12}$ Washington Bee, August 10, 1901; New York Age, December 3, 1908.

${ }^{13}$ E.M. Woods, The Negro in Etiquette: A Novelty, (St. Louis, 1899); Richard R. Wright, Jr., "The Economic Condition of Negroes in the North," Southern Workman 40 (May 1911): 306; Ida Joyce Jackson, "Do Negroes Constitute a Race of Criminals?" Colored American Magazine 12 (April 1907): 252-263; DuBois, "The Black North;" R. Henri Herbert, "Our Problems and Our Burdens," Colored American Magazine 12:5 (May 1907): 346.
} 
tourists, they demanded entrance to crowded boardwalks and other cheap amusement venues.

The popular appeal of the excursions made it increasingly difficult for conservative black leaders to contain the activities of black working-class consumers. Throughout the 1880s and 1890s, more and more black laborers left behind the folk traditions and local leisure districts of Philadelphia, New York City, and Baltimore for the diversified marketplaces of the Jersey shore. Out of the watchful eye of moral guardians, and unrestrained by local politics, black tourists adopted the language, behavior, and political sensibilities of free consumers. Worried that unrestrained consumption would bankrupt black laborers and incite white backlash, elite blacks kept a close watch over the behavior of excursionists and pressured promoters and religious groups to curtail their activities.

To the North's more conservative black reformers, the appeal of commercial leisure posed a direct challenge to traditional conceptions of race, gender, sexual morality, and political economy. To these elite black leaders, excursions gave license to immoral and indecent behavior that discredited careful savings, humble living, and public propriety; capitalistic prerequisites that many believed secured their own financial success and good character. In turn, they pressured churches and fraternal bodies to eliminate the excursions altogether. Reverend R.R. Downs of Philadelphia lobbied area organizations to disallow the practice, noting that they "are a curse to the people of the Negro race, an injury to them financially and morally, destructive to both religion and society." Highlighting the example of many excursionists who "with barely a decent chair in the house spends nearly ten dollars fixing for the excursions," Downs reiterated 
the sentiments of many conservative northern blacks who questioned the day-to-day decisions of working-class residents. He pointed out that too many participants were "too poor, children too barefooted and ragged," and their "homes too scantily furnished" to spend extra money on day trips to the seashore. ${ }^{14}$

The economic relationships that formed between churches and excursion outings also prompted many critics to question whether black ministers should be involved in coordinating and funding excursion trips. Noting that it causes "too many people to lose faith in the financial institutions of the church," Downs exclaimed that the inability to separate faith and finance from such activities left working-class blacks at the mercy of swindlers and susceptible to fraud from potentially corrupt religious leaders. For traditional religious figures like Downs, churches were to serve black parishioners and congregations in moral matters. While social welfare operations were encouraged, Downs wondered whether the promotion of consumption-oriented activities and profit-making schemes-however well intentioned—disrupted the appropriate ecclesiastical distance necessary to attain moral authority and uphold traditional ideas of political economy. "Loss of respect for the pulpit," Downs lectured, is inevitable when religious figures become immersed in the profit-making schemes of entertainment. "The Preacher is looked upon as a railroad agent, a huckster of tickets, both manager and flunkey on the train." Becoming part of the hustle itself, Downs argued that excursions placed preachers and other religious leaders into the raucous and deviant fray of the "bowery," embedded in the hisses, cat-calls, and jive-talk of such scandalous spaces. In "attempting to play the gallant in providing the comfort of ladies," Downs noted that instead, moral figures found themselves, "jested, hinted at," and returned home "assailed by scandalous rumors." No

\footnotetext{
${ }^{14}$ Reverend R.R. Downs, Christian Recorder, June 29, 1893.
} 
one placed in such a precarious environment, he reasoned, could "maintain his dignity and run an excursion at the same time."

The vulgar language, coarse behavior, and sexual tension of the excursion train was particularly troubling for northern blacks who wished to discredit the image of black female impropriety. Observing the give-and-take between female passengers and male suitors on excursion trains, Downs exclaimed that even the most innocent of women are given over to the "hounds." "The abandoned women glories and exults in her shame. She sits in the laps of men associates, who regard it as fun." Even respectable females, Downs acknowledged, became entangled in the seditious trap of crude language, binge drinking, and sexual gropes. "Females, who respect themselves," he narrated, "hurridly leave one coach to go to another, while the polluted queens of the slums display their degradation and beastly propensities." Husbands who dropped off innocent young women, returned later to collect "disgraced wives;" their homes thereafter fouled by "enraged husbands."15 In 1896, the Federated Colored Women's Club thus moved to abolish all excursions to the shore, explaining as Downs did, that "not a too few ruined women can date the beginning of their downfall to their first ride on one of these short trips."16

In his critiques of black excursions, Downs was accompanied by the editorial rebukes of the northern black press, who kept a watchful eye on blacks' recreational outings. A reporter for the New York Age recounted to black leaders the "deplorable acts" of black men and women who arrived in excursion cars. "Just picture in your mind a tarin of eight or ten coaches," the Age reporter declared, "literally packed with men, women, and children until standing room is at a premium." Add to that the "whiskey in

\footnotetext{
${ }^{15}$ Ibid.

16 “Club Work Among Colored Women," Colored American Magazine, August 1906.
} 
abundance, cigars, tobacco, bad language, whooping and yelling, and you have a fair sample of the average Sunday excursion." ${ }^{, 17}$ The concerns expressed by the Age and other periodicals troubled many northern blacks that worried about the public image leisure outings inflicted on white observers. Bystanders who witnessed an 1883 brawl in Lakeside Park recounted later that even respectable African American tourists were sometimes taken to violence when "loaded up with bad rum." On one Sunday afternoon in particular, an excursion party descended into a street brawl as "knives, razors, and blackjacks flashed through the air," an event that one black observer acknowledged was the "most boisterous crowd of excursionists that ever visited Lakeside Park."18

It was not just violence, however, that attracted the judgment of black elites and religious figures. Seemingly innocent popular cultural traditions like the "cakewalk" became scenes for white ridicule and black moral instruction. Popular among black tourists of all social classes, the cakewalk appeared to many African American participants to be an innocent amusement activity. For whites, though, the cakewalk became a voyeuristic stage upon which to ridicule black comportment and social expression. The Philadelphia Record recorded that white attendees "enjoy the antics of the carefree colored folks." ${ }^{19}$ Attuned to these Jim Crow judgments, cautionary black leaders saw within the theatrical displays of the cakewalk a minstrel act for white amusement and a cultural justification for exclusionary public policies. Observing the scene for himself, Pastor Elijah Jenkins of Atlantic City instructed his congregation to avoid the cakewalk competition, an act that in his view was the "most degrading spectacle, which Atlantic City offers her visitors." To skeptical black participants, he

\footnotetext{
${ }^{17}$ New York Age, June 2, 1888.

${ }_{18}^{18}$ Philadelphia Tribune, February 24, 1883.

${ }^{19}$ Philadelphia Record, September 4, 1898.
} 
instructed them to observe the smiling faces and mocking gestures of white observers, reiterating, "white people go because they always like to see the colored man make a fool of himself., ${ }^{20}$

In Asbury Park, where racial tension and civil rights protests had been a definable part of the political culture during the 1880s and 1890s, divisions among blacks over civil rights became most pronounced. To some church leaders, civic reformers, and local business owners, Asbury Park was more than an excursion destination. Many longstanding residents operated cottages, inns, and other modest enterprises, and in the offseason managed social welfare agencies for seasonal workers. They formed partnerships with Asbury Park's white officials, including James Bradley, whose collegial relationship with West End leaders and generous financial contributions, led many long-time residents to defend the Mayor's policies throughout the 1880s and early 1890s.

In a public defense of James Bradley in 1887, Reverend Gould of West Asbury Park noted angrily that black citizens were routinely the beneficiaries of the Mayor's generosity. Denouncing civil rights protests, he argued that those who objected to the color line were members of the community who had made their presence unwelcome by unruly and "objectionable behavior." Although he acknowledged that recently instituted segregation laws concerned many year-round residents, he also insisted that the "spirit" of Asbury Park was "as liberal as is generally found" in any other northern community. "There may be traces of the color line visible," Gould acquiesced, yet "when the average colored man or woman shall meet the average white with the same gentlemanly and ladylike courtesies and bearings, I do not believe the color line will amount to much.” Objecting further to the "uncouth and unbecoming manners" of black working-class

\footnotetext{
${ }^{20}$ Philadelphia Evening Bulletin, September 8, 1905.
} 
citizens and tourists, Gould called on his community to be as vigilant in enforcing fairness and equality as they were in calling on the town's white citizens to uphold. "While we ask our white brother and sister to lay aside their prejudices, we must not forget," he insisted, "to lay aside our own, and if possible treat them with more of a Christ-like spirit than is manifested by them toward us."21

Gould was not alone in Asbury Park in calling for a referendum on the behavior of working-class blacks. Reverend John P. Sampson of the AME Church broke rank with his fellow ministers and approved Bradley's actions, refusing to attend the civil rights meetings or to endorse the group's political protests. Along with A.W. Lowrie, pastor of the Baptist Mission, the two defended Bradley to the Asbury Park Press, noting that, "in regard to bathing facilities for the colored people, the colored people as a rule, were satisfied with the change."22 To mobilize against the West End's civil rights coalition, they joined outspoken members of the black ministry and neighboring black civic leaders in Philadelphia and New York. These groups insisted that class, not race, should dictate the shore's social and cultural boundaries. Labeling themselves the "better elements," they sought to distance themselves from "the speakers at the indignation meeting." Instead, they singled out the agitation to the "floating colored population" who "abused their privileges," and promised to hold their own meeting "at which they will approve Mr. Bradley's action in the matter."23

Echoing the sentiments of Asbury Park's conservative black clergy was Col. William Murrell, a politician and editor of the New Jersey Trumpet, who spent most of

\footnotetext{
${ }^{21}$ The Christian Recorder, Aug. 11, 1890.

22 " The Colored People Satisfied," Asbury Park Press, July 15, 1890; "That Vexatious Bathing Question," Asbury Park Press, July 14, 1890.

23 “The Better Elements Views," New York Times, July 2, 1887.
} 
his summers at Asbury Park making acquaintances with James Bradley and other influential white officials in the shore town. Defending the policies initiated by the Mayor to separate white and black vacationers, Morrell offered a scathing rebuke of black workers and their integrationist backers. In particular, Murrell criticized civil rights protestors who refused to recognize or endorse traditional interpretations of market theory and social customs. "In ordering the scum of my race to keep away from the pavilions, Mr. Bradley is right.. ${ }^{24}$ For Murrell and others who defended the actions of Bradley, the denial of equal access to leisure illuminated not just accommodationist rhetoric and class-infused moral judgment, but dovetailed with disagreements about political economy. Civil Rights advocates argued that the right to consumption was equal to the right to property. Conservative black leaders like Murrell offered a more traditional explanation of public space and market relations. "Decent color people are not obtrusive and do not monopolize seats or make loud and insulting remarks," Murrell pointed out. "Mr. Bradley owns the pavilions and can keep anybody out if he liked to." Reiterating that consumer rights was not absolute, he concluded by stating, "it is nobody's business" but his. "If I owned Asbury Park I would drive these people away." 25

The argument against civil rights activism by some of Asbury Park's conservative black leaders represented the judgment evoked by many successful conservative nineteenth century black activists that the route to success in life was not to be found through collective action, political protests, or rejecting traditional marketplace principles. In an earlier nineteenth-century debate over the proper path to prosperity, the famous political activist Samuel Cornish exclaimed that "each one for himself, must

\footnotetext{
24 “Commends Mr. Bradley,” The Sun (NY), July 21, 1893.

${ }^{25}$ Ibid.
} 
commence the improvement of his condition." It is "not in mass," he declared, but in "individual effort, and character, that we are to move onward. ${ }^{26}$ Morell and other prominent entrepreneurs who repeated Cornish's judgments considered their own humble origins and successful careers a blueprint for entrepreneurial success and social satisfaction. Dreams of integration were not only impractical as business-minded black leaders reasoned, but they also fed black workers to the vice-ridden activities that stunted their upward mobility, left them impoverished, and hardened the exclusionary resolve of segregationists.

Eager to highlight the political arguments of the region's conservative black leaders, the white press picked up on their announcements and activities to marginalize the West End's civil rights protests, praising Gould, Sampson, Lowrie, and Murrell for their reasoned approach to racial politics. Covering Asbury Park's racial tension in 1890, the New York Times noted that civil rights activists were "a few too conspicuous colored men," and that the "attack was promptly resented by the better class of colored people." Given the continued racial tension and civil rights protests that gripped Asbury Park throughout the decade, the Times' coverage appears ill-informed and premature. Yet its in-depth look at blacks' political disagreements displayed the contentious nature of black politics over the issue of integrated leisure, as conservative black leaders debated with black activists in defining civil rights, public behavior, and political economy.

Despite their reluctance to embrace civil rights protests during the 1880s, Asbury Park's black business class remained sensitive to their economic and political

\footnotetext{
${ }^{26}$ Quoted in Patrick Rael, "The Market Revolution and Market Values in Antebellum Black Protest Thought," in eds., Scott C. Martin, Cultural Change and the Market Revolution in America, 1789-1860 (Lanham, Md, 2005) 31.

27 “Asbury Park: The Colored Question Settled,” New York Times, July 20, 1890.
} 
vulnerability, even when they supported local authorities. The Christian Recorder, for example, explained that its defense of James Bradley was rooted in the financial backing and generosity of the Asbury Park Mayor. "He gave us a lot on which the Church property stands today," the town's ministers declared, "and he gives employment to hundreds of our people...It would come in bad taste for us to lead in a crusade against the good name of founder Bradley. ${ }^{, 28}$ Yet to many local black businessmen, such statements reiterated and reinforced the lack of viable entertainment and consumption options for black consumers.

Since the antebellum period, many leading black intellectuals and activists spoke openly and frequently about solving the dilemma, as Martin Delany aptly put it, where "white men are producers" and "we are consumers." In a sentiment drafted by many black entrepreneurs at the Jersey shore a half-century later, Henry Bibb declared defiantly in 1851 , "we must consume what we produce. ${ }^{, 29}$ For those who embraced the market revolution during the antebellum era, the goal was often economic interdependence rather than isolation. " ${ }^{30}$ "An address to the colored people" of Cleveland, Ohio, dated September 6, 1848 declared to those in attendance that northern blacks should strive to "make white persons as dependent on us, as we are upon them."”31 Turn-of-the-century black advocates, however, were not so ambitious to reconfigure the market culture or Jim Crow system of the Jersey shore. Instead they called on black workers and tourists to boycott Jim Crow leisure spaces.

\footnotetext{
${ }^{28}$ Christian Recorder, July 27, 1893.

${ }^{29}$ Henry Bibb, "Voice of the Fugitive," March 26, 1851.

${ }^{30}$ Patrick Rael writes that "Black leaders strove not so much for independence from whites as for a greater degree of mutual dependence between whites and blacks. They strove not so much for the early republic's concern with economic and hence political independence as they did the Jacksonian era's gradual concession to the developing fact of economic and social interdependency among all." Rael, 34.

31 "An Address to the Colored People of the United States," in Report of the Proceedings of the Colored National Convention, Held at Cleveland, Ohio, on Wednesday, September 6, 1848 (Rochester, NY, 1848).
} 
The urgency with which many black civic leaders and entrepreneurs approached these matters in the 1890s and early 1900s reflected, in part, the rapid development of segregation at the Jersey shore in the preceding decade. In 1883, a correspondent for the New York Globe noted that in Atlantic City, "we learn of one of two kept" places that refuse black patrons, "but it is not general and our race do a good deal of business." Prejudice," the Globe exclaimed, "is not felt here. ${ }^{, 32}$ Although Atlantic City would not begin to institute segregation officially until 1904, many black leaders of the resort town's "Northside" felt the pressure of Jim Crow's cultural and economic power rapidly mounting in the 1880s and 1890s. Black domestic workers, for example, who had been a mainstay in northern resort towns since the antebellum period were slowly being replaced by white female "help" at the turn of the century. White tourists welcomed the change as long overdue by expressing their distain for the "poor service" and incessant political demands exhibited by the city's black domestic servants. A drummer for a white traveling band in 1903 noted that many whites began to abandon hotels that employed only black waiters. "It is not the tip they object to," he explained, "for girls get that, too; but it is the poor service they get unless a colored waiter feels sure beforehand he is going to get something., ${ }^{33}$

In the years immediately following the Plessy decision, it was not enough for black leaders and capitalists to push for behavior modification or consolidate class status. In northern resort towns, and elsewhere, blacks consumers faced a tightening of entertainment options in white-controlled economies, and black workers found their employment opportunities increasingly restrained by a diversified labor pool. By the

\footnotetext{
${ }^{32}$ New York Globe, July 28, 1883.

33 "Prefer Girls as Waiters," New York Times, July 2, 1903.
} 
1890s, religious leaders, civic boosters, and small-business owners began to boycott Jim Crow restrictions - exhibiting collective action and individual creativity — to combat the shifting racial politics and financial realities of the region's political economy. In keeping with the moral reform impulse of many black progressives, local blacks also sought to reconfigure the ideas associated with public leisure, moving to eliminate degrading amusements and scandalous entertainment venues that made black communities the focus of national ridicule, local police raids, and curious "slummers" in other northern cities.

In an effort to promote intraracial consumption, northern black activists scorned the influx of "Black and Tans" and other interracial social clubs that proliferated in many urban centers in the post-Civil War North. Throughout major northern cities, the "Black Bottoms," "Badlands," and “Tenderloins" of Chicago, New York, and Philadelphia became synonymous with social recklessness and sexual deviancy that the white sociologist Walter Reckless described as the defining features of "open Negro community life. ${ }^{34}$ In an era in which segregation was best understood through the political vocabulary of privacy and property rights, the idea of an "open community life" symbolized to many white northerners an alternative political economy that made deviancy both exotic and dangerous to those on the other side of the color-line.

One such individual who best understood the economic and moral stakes of segregation was George Walls. A long-time resident of Atlantic City, Walls was a familiar face to both white and black tourists in the shore town during the early Jim Crow period. In 1894, he teamed with other local businessmen to fund the Northside's first

\footnotetext{
${ }^{34}$ Quoted in Mumford, Interzones, 41.
} 
YMCA after recognizing the lack of recreational venues available to black residents. ${ }^{35}$ Walls' entrepreneurial ventures were not limited to the Northside, and in the years that followed, he founded and helped run a popular bath house for both white and black sunbathers on Texas Avenue. ${ }^{36}$ Like the publicity that accompanied the opening of the Dale Hotel, the northern black press hyped Walls' establishment as a glowing example of financial ingenuity and racial progress. One northern newspaper touted it as the "Great Mecca" of black leisure accommodations, noting with pride that "this place is of the colored people, by the colored people, and for the colored people." Unlike many black venues that were tucked away from Atlantic City's boardwalk marketplace, Walls' bathhouse straddled the city's informal Jim Crow line. On sun-soaked summer days, white bathers carved out convenient spots in the sand directly in front of Walls' establishment. Black bathers, however, were encouraged to walk two blocks to the assigned Jim Crow beach on Missouri Avenue. The spatial parameters of northern segregation culture - reflected on crowded beaches in many summer days at Atlantic City—prompted many black residents and local businessmen and women to reconfigure their approach to leisure and consumption. ${ }^{37}$

Joining Walls in building a separate amusement district for black tourists was B.G. Fitzgerald. Fitzgerald, who had moved to Atlantic City from the South in the 1890s, quickly discovered the lack of leisure accommodations for black consumers. Traveling Atlantic City's famed boardwalk upon his arrival, he observed the seemingly endless array of amusement venues, snack stands, and bathing pavilions operated and attended by

\footnotetext{
${ }^{35}$ Lola L. Allen, "Social Agencies," Federal Writers Project, N.J., New Jersey Ethnic Survey, Box WK-2, 2123.

${ }^{36}$ Milton Palmer, "The Negro in Business," Federal Writers Project, N.J., New Jersey Ethnic Survey, Box WK-2, 2123.

${ }^{37}$ Walls Family Photo Collection, Alfred M. Heston Collection, Atlantic City Free Public Library.
} 
white businesses and guests. Yet not only did many of these businesses exclude black patrons, but none of them were run by African Americans. In response, he opened his own multi-purpose venue in the heart of the Northside's excursion district in 1899. Like Walls' bathhouse, Fitzgerald Hall became a popular destination for out-of-town black guests as well as local residents. Admission to the two-story structure invited guests to seek relaxation and companionship in the building's café, saloon, dancehall, or poolroom, each of which became a go-to stop for black consumers on hot summer nights. ${ }^{38}$ To members of the black northern press who had championed the construction of black resorts since the 1880s, the Fitzgerald Auditorium solved a pressing economic and cultural need. In 1906, the Colored American Magazine praised Fitzgerald's for highlighting the solvency of investing in black leisure. "The few places that may object to our presence," a local correspondent noted, "are teaching us a lesson the meaning of which is to spend your money among your own people."39

In a bold move to shield black patrons from public ridicule, as well as to ensure the economic solvency of these early black businesses, George Walls petitioned the city council in 1906 to segregate the beaches by law. In Walls' mind, the move served two purposes. First, he saw the measure as a protection for black business owners and a legal sanction to what had already been established by custom. Second, he and other black business owners and politicians realized the danger inherent in the political bargaining power some members of the community waged against white proprietors. While black protests and mass demonstrations helped undermine the cultural value that whites assigned to certain leisure spaces, the political tactics were also economically damaging

\footnotetext{
${ }^{38}$ Federal Writers Project, Works Progress Administration, "Atlantic City Industrial Improvement Company," Atlantic City Historical Society, 1-3; and "Recreation."

${ }^{39}$ Colored American Magazine, October 1906.
} 
to black workers. ${ }^{40}$ When black workers of the Albion Hotel went on strike in 1899 , the hotel's manager dismissed the workers from their posts and replaced them with an allwhite wait staff the next day. ${ }^{41}$ Several years later, another labor strike threatened to end black domestic work in the city. In 1906, waiters at the Marlborough Blenheim Hotel struck for a $\$ 5.00$ per month increase in wages. The waiters argued that the proposed wage increase would compensate them for the added service requirements that the hotel's management added to their daily duties following an expansion of the Hotel's major dining rooms. After refusing to work until the wage increase was instituted, the hotel's management promised to adjust the staff's wages to $\$ 25.00$ per month, up from the \$20.00 per month they had been receiving. By the end of the 1906 summer season, though, management refused to make good on their promise. When the 1907 summer season opened, the Marlborough Hotel no longer employed black waiters. ${ }^{42}$

By the early 1900s, domestic service workers were not the only ones feeling whites' resolve to enforce Jim Crow. The popular shore town underwent a construction boom during the first two decades of the twentieth century. Bricklayers, hod-carriers, and road-crew workers were needed to keep up with the bevy of new projects that contributed to Atlantic City's expansion, and many black workers believed they would be again called on to complete the work. However, many black applicants increasingly found themselves excluded from such projects. A mechanic who took odd jobs for the city throughout this time admitted, "as soon as white mechanics knew of a Negro mechanic on a job, they would immediately refuse to proceed with the construction of a job regardless of the location. Harry Jump, a white contractor employed in Atlantic City

\footnotetext{
${ }^{40}$ Ibid., "Recreation," 16.

${ }^{41}$ Atlantic City Daily Union, August 11, 1899.

${ }^{42}$ Milton Palmer, “Labor,” Federal Writers Project, N.J., New Jersey Ethnic Survey, Box WK-2, 2123.
} 
explained to another black job seeker that "if you are alone and in dire need of work, I can give you something to do but not with white mechanics, because they will not work with you." These developing Jim Crow restrictions led many black laborers to seek private work, which excluded them from membership in local unions. As one worker recounted years later, "I went to work on private jobs for myself and needed the support of the union, which I was denied. They refused to furnish me with men, forcing the curtailment of several jobs. ${ }^{.43}$

The revaluation of black labor by white businesses and contractors led to a growing unemployed class that languished in Atlantic City's Northside. Even in boom times, living conditions for many blacks had been bleak. Most seasonal lodgers were jammed together in cramped, dingy, and unsanitary spaces. Year-round residents often suffered the worst. Unemployed, in debt, and in bad health, they faced the brunt of the city's seasonal work rhythms. By the early-twentieth century, many sections of the Northside were falling apart or condemned by the city. Unable to finance home repairs themselves, renters were left to suffer from the abuse of unresponsive, negligent, and exploitative landlords. ${ }^{44}$ Just as damaging was the decrepit visual picture that black poverty rendered to whites, who used the imagery of urban decay to degrade black living situations and forstall integrated leisure and free consumption. An illustrated handbook of Atlantic City, edited by the town's major tourist promoter Alfred Heston, explained that

\footnotetext{
${ }^{43}$ Ibid.

${ }^{44}$ Margaret L. Brett, "Atlantic City: A Study in Black and White," Survey Magazine, Vol. 28 (1928);

Milton Palmer, "Economic Shifts and Migratory Influences," New Jersey Ethnic Survey, Box WK-2, 2123.
} 
the region's "colored people come here for the purpose of doing laundry and waiting, and their children are bottle fed and neglected." 45

These factors forced many black reformers to abandon their early ideas about the roots of black poverty. Instead, they argued that the exploitative practices and policies of Jim Crow rendered many hard-working men and women trapped in an increasingly segregated service economy maintained and promoted by white authorities. Black entrepreneurs and local civic leaders like George Walls and B.G. Fitzgerald thus pushed to reconfigure the labor and consumption options of the Northside. With her husband Alonzo, local activist and entrepreneur Maggie Ridley spearheaded efforts to shield black tourists and workers from both the indignities of the city's Jim Crow hotels as well as the unseemly slums of the Northside. Together they funded and operated affordable, safe, and sanitary boarding houses for workers in the 1880s and 1890s. In 1900, the Ridley's used the profits from these early ventures, along with a loan secured from the Northside Credit Union, and opened a more lavish hotel, the Hotel Ridley. The Hotel Ridley quickly became a popular and sought-after spot for out-of-town black guests, particularly middle-class tourists who wished to enjoy respectable accommodations worthy of their striving status. ${ }^{46}$

To market the development of the Northside's tourist industry, Walls, Fitzgerald, and the Ridleys used advertisements and other promotional campaigns to counter the disparaging images of and narratives about black residents. A lengthy profile on the opening of the Grand Hotel in Atlantic City typified the selling features of respectable

\footnotetext{
${ }^{45}$ Alfred M. Heston, Illustrated Handbook of Atlantic City, (Atlantic City, NJ: A.M. Heston and Company, 1888), 124.

${ }^{46}$ Milton Palmer, "Earning a Living in Atlantic City,” Federal Writers Project, N.J., New Jersey Ethnic Survey, Box WK-2, 2123.
} 
tourist accommodations and the importance of adequate leisure amenities for black vacationers. Unlike many of the city's hotels and boarding houses, the Colored American noted that the Grand Hotel was an ocean-front venue with clean sight lines of the sea, boardwalk, and the city's main thorough-fare of shops, restaurants, and cheap amusements. Positioned within the confines of Atlantic City's "white" resort area, the owners of the hotel touted it as a respectable and affordable place for black tourists to enjoy environmentally safe accommodations. "We can breathe in comfort without being ostracized," its proprietors declared, with assurances that an "imposing pavilion" will allow bathers to "freely breathe the ozone from the ocean." Additional consumer features included poolrooms with shuffleboard, a barbershop, dinning rooms, dancing parlors, and an ocean café. ${ }^{47}$

In place of the typical portrait that whites painted of ramshackle tenements and illicit behavior, black proprietors touted clean, comfortable, private rooms, with reasonable rates, ocean views, and modern amenities. Additional advertisements in national publications urged tourists to visit the city's Harlow House, "the largest and most comfortable house for colored people in Atlantic City." In close proximity to local railroad depots, the Harlow house, its proprietors argued, served "first class meals every week. ${ }^{, 48}$ Other local tourists were urged to take up residents in the Clinton Cottage, which offered "moderate prices" and an Ice Cream parlor, the Ormond, which catered to "guests requesting a European or American style plan," the Cape May House, which offered "airy rooms," "Hot and Cold baths," and a wide selection of "choice wines and liquors," or the Banneker House, which invited "friends and visitors" to frequent a

\footnotetext{
47 "The Grand Pacific Hotel: The Afro-American Gets a Place on the Boardwalk at Atlantic City," Colored America, April 15, 1899.

${ }^{48}$ People's Advocate, July 21, 1883.
} 
summer boarding house where "every effort will be made to provide for the comfort of guests. $" 49$

These early ventures would form the foundation of a much larger mission envisioned by Walls and other local business owners to lure additional black investors and capital to the region. In an 1899 prospectus, Walls explained that Atlantic City's white population endorsed the economic proposals and that black investors could be confident that the resort community "employs more Colored men and women than any other city in the country." For those concerned about the region's developing Jim Crow culture, Walls confidently reassured them that the community's black tourists and working classes "enjoy more privileges than in any other city of its kind in the United States. ${ }^{, 50}$ He was not alone in lobbying for the measure. Throughout the resort town, many black, working-class residents were beginning to see claims to integration as dangerous to employment opportunities. These black businessmen and working-class citizens came to use segregation as a cultural and economic defense strategy to provide employment security and disentangle them from the racial confrontation and indignities they sometimes faced in designated white areas. To potential investors, black boosters reassured their constituents that the development of the city's northern sector would serve as a model for other black resorts: a blueprint for black cultural autonomy and economic prosperity—aided by “white friends.",

Fitzgerald's Auditorium, the Grand Hotel, the Hotel Ridley, and the Dale Hotel thus served to persuade national readers that black-owned leisure establishments were popular, respectable, and profitable. An advertisement for a proposed Atlantic City hotel

${ }^{49}$ Colored American, May 6, 1899; People's Advocate July 21, 1883.

${ }^{50}$ Ibid., "Recreation."

${ }^{51}$ Atlantic City Sunday Gazette, June 29, 1906, 4. 
in 1921 alerted investors of the financial possibilities for savvy and creative entrepreneurs. Published in black newspapers throughout the east coast, John W. Lewis called on black entrepreneurs to buy shares in the Ovington Hotel, which was to be built on the corner of Pacific Avenue, one block from the center of Atlantic City's main boardwalk complex. Marketing the financial potential of the project as a "sound and worth-while race proposition," Lewis called on skeptical investors to "get into an enterprise that the public will support, and get into it before most people awake to its possibilities, here lies the secret of fortune." As Lewis's proposal indicates, the attraction of black-owned leisure lay not only in its reaction to segregation, but also in its unique and profitable potential for black capitalists. Indeed, the unique position of the proposed project, which would place it in close proximity to many white-owned establishments, informed many northern blacks that the emergence of segregation at the shore did not mean that African Americans needed to abandon recreational and economic pursuits, nor would they necessarily have to resign themselves to being confined to the margins of commercial life. ${ }^{52}$

The development of Atlantic City's Northside in the first two decades of the twentieth century was indicative of black investors' and entrepreneurs' efforts to construct a black resort industry nationwide. Throughout the South and Midwest during the Reconstruction period, black businessmen began to cater to tourists in "black Chautauquas" and other black-owned resort communities. Besides a recreational sanctuary for safe and secure fun, these resorts were self-improvement retreats that offered a place for political organization and racial uplift. By the early- twentieth century they became part of a broader postwar leisure tradition — championed by both whites and

\footnotetext{
52 "Invest in a Sound and Worth-While Race Proposition," Washington Times, May 31, 1921.
} 
blacks — of balancing recreation with self-improvement. For many northeast black boosters, however, these black resorts offered a more practical and profitable solution to the endemic racial confrontation and economic exploitation they faced from white tourists and financial institutions. ${ }^{53}$

In addition to the problem of adequate housing and tourist accommodations, the development of segregation along the Jersey shore also forced many African Americans to reconsider their labor options. In a reversal of the "wages of whiteness," the increase of white domestic labor in Atlantic City significantly depressed wages for all waiters, hotel attendants, and service workers and in particular for African Americans workers. ${ }^{54}$ The effects of these changes threatened not only to end the golden period of available and lucrative work for African Americans, but also threatened to close off sites of consumption to black workers and tourists. As many local residents and reformers understood, the civil rights achievements of the 1880 s centered on the availability and desirability of black labor. Unable to secure other labor alternatives, white business owners were often forced to concede to the integrationist demands of black consumer advocates. Yet, as more and more white proprietors secured affordable and socially acceptable labor alternatives after 1900, many African Americans decided that the availability of work and the promise of free consumption could only be attained through a regional boycott of white establishments and a reconfiguration of black labor.

\footnotetext{
${ }^{53}$ Cindy S. Aron, Working At Play: A History of Vacations in the United States (New York, 1999) 213; Adelaide M. Cromwell, "The History of Oaks Bluffs as a Popular Resort for Blacks," Dukes County Intelligencer 26 (August 1984); Carroll Greene, Jr., "Summertime- - In the Highland Beach Tradition," American Visions 1 (May and June, 1986); Kahrl, The Land Was Ours; Marsha Dean Phielps, An American Beach for African-Americans (Gainesville, FL, 1997); Lewis Walker and Benjamin C. Wilson, Black Eden: The Idlewild Community (East Lansing, MI, 2002).

${ }^{54}$ Palmer, "Economic Shifts and Migratory Influences."
} 
What had begun as a solution to housing deficiencies set off a broader debate over the role of black labor and consumption in leisure settings, particularly communities that housed a sizable year-round population. This was not necessarily a new discussion. In the 1840 s and 1850s, many northern black leaders spoke resolutely about the problem of domestic service. National Convention goers in 1848 drafted a statement denouncing the restrictions placed on black labor. They declared that "the occupation of domestics and servants among our people is degrading to us as a class, and we deem it our burden and duty to discountenance such pursuits. ${ }^{, 55}$ For a brief period, preoccupation with the Civil War, emancipation, and Reconstruction politics shifted national priorities to political and legal matters. However, the re-emergence of segregation at the Jersey shore after 1900 renewed calls from many black leaders to re-think their economic position in the labor market. For black workers eager to leave behind their posts in domestic service, Maggie Ridley's Atlantic City chapter of the Young Women's Christian Association (YWCA) was a necessary and popular destination. To fund the operation, Maggie secured partial funds obtained from the successful Hotel Ridley along with additional money procured from private donations. A gathering place for female professional development, Maggie and her associates taught aspiring white-collar women occupational skills and marketable professional traits. Although the staff also provided a centralized system for locating domestic work in the city, the YWCA's primary function was to coordinate the staffing needs of black businesses and prepare market-ready and talented black women for work in a largely white-dominated professional service industry. ${ }^{56}$

\footnotetext{
55 "Report on the Proceedings of the Colored National Convention Held in Cleveland," 1848, in eds. Patrick Rael, Pamphlets of Protest: An Anthology of Early African American Protest Literature, 17901860, (New York, 2001), 186.

${ }^{56}$ Palmer, "Economic Shifts and Migratory Influences"; See also, Johnson, The Northside, 130.
} 
Throughout the early twentieth century, the increasing role of intellectual agencies and employment networks like Maggie Ridley's YWCA were indispensable for northern black job seekers. Besides the influx of white service workers, by 1900, black community organizers were increasingly professionalizing retail and service work in the city. Attuned to the changing make-up of their service industry, long-time headwaiters, hotel attendants, and other members of the black service "elite" instituted entrance exams and tightened employment qualifications for black applicants in order to retain their jobs. Many of them also joined the growing number of "Colored Waiters Unions" to combat unequal pay, degrading treatment, and to mobilize against resort communities who no longer regarded their labor as indispensable ${ }^{57}$ Not only did these decisions isolate the resort's most marginalized and vulnerable black laborers, they significantly cut down on the civil rights agitation and racial tension of the city's main marketplaces, forcing many black tourists to seek out alternative consumer choices.

These shifting economic dynamics significantly affected the employment roles and options of black women, prompting female entrepreneurs at the Jersey shore to carve out new consumer industries that black female workers staffed and cater to the unique and in-demand consumer tastes and styles of black women. Like Maggie Ridley, Madame Sara Spencer Washington resented the notion that women were relegated to domestic service. An innovative pioneer in beauty culture and black consumer tastes, Madame Washington moved to Atlantic City in 1913 and quickly established herself as a fashion mogul and formidable entrepreneur among Northside residents. Throughout the first half of the twentieth century, she built a profitable and popular beauty culture empire that included a beauty school, hotel and resort complex, industry newsletter, delivery and

\footnotetext{
57 “Negro Waiters to Organize,” New York Times, September 17, 1899.
} 
distribution service, golf course, and an untold army of beauty school agents who bought, sold, and manufactured her products nationwide.

Trained in chemistry, Madame Sara Washington bought raw materials wholesale from local and regional distributors and mixed her own products, peddling make-up and hair products door-to-door to customers in the Northside. By 1920, she saved up enough money to open the APEX Hair and News Company. Training local young women, she eventually established the APEX Beauty College that marketed products and beauty training to black clientele throughout the Mid-Atlantic region. In an age in which northern employment patterns were spatially coded by racial customs and exclusionary public policies, the APEX business model offered successful female beauty agents the opportunity to transcend the political and cultural realm of Jim Crow. ${ }^{58}$

By the 1920s, Madame Washington's APEX enterprises formed part of a broader style war-taking place in Jim Crow America. For much of the late-nineteenth century, the black beauty industry was viewed as a frivolous activity that sidetracked young women from more professional and refined pursuits. ${ }^{59}$ Washington, however, saw a more enterprising, empowering, and uplifting message in the promotion of beauty products among black women consumers. She used her APEX enterprises to uplift struggling and poor black women, marketing the APEX system as a "scientific" profession that led working-class women toward financial independence and race pride. Through relentless

\footnotetext{
${ }^{58}$ Palmer, "The Negro in Business," Washington Afro-American, “Apex Hair Co. Head Lies Critically Ill," March 24, 1953.

${ }^{59}$ Julia Kirk Blackwelder, Stylin Jim Crow: African American Beauty Training During Segregation (College Station, TX, 2003); A'Lelia Perry Bundles, On Her Own Ground: The Life and Times of Madam C.J. Walker, (New York, 2001); Margaret Finnegan, Selling Suffrage: Consumer Culture and Votes for Women (New York, 1999); Noliwe Rooks, Hair Raising; Beauty Culture and African American Women (New Brunswick, NJ, 1996); Stephanie J. Shaw, What A Woman Ought to Be and Do: Black Professional Women during the Jim Crow Era (Chicago, 1995); and Victoria Wolcott, Remaking Respectability: African American Women in Interwar Detroit (Chapel Hill, 2001).
} 
ambition and clever marketing, the APEX business model promoted respectability and lucrative work. An advertisement marketed to aspiring agents displayed the image of a professionally dressed and confident black female agent. Above the image, was printed the message: "Now I am my own boss." The signage was accompanied by a short biography of the agent, noting her humble origins, struggle to find suitable employment, and financial independence after becoming an APEX agent. "Several years ago," the ad narrated, "she wondered what to do about her future." Yet, having completed the necessary course work to become an APEX agent, the woman was now "her own boss" and "owns her own home." Mirroring the individual effort and relentless ambition of Washington's own rise to wealth and fame, the ad motivated young women to believe that the path to prosperity was achieved through "your own efforts. ${ }^{" 60}$ For black women stuck in the marginalized and anonymous sector of domestic service, the APEX Beauty College offered profitable trade skills in a modern service industry that championed beauty, individual style, and social recognition for African American women.

To black female consumers in Atlantic City, the APEX product line touted individual cultural expression, race pride, and feminine virtue — traits and skills that were denied to many black women by a northern Jim Crow culture that regularly mocked and ridiculed the public appearances, activities, and consumer tastes of striving black women. In a promotional brochure distributed to aspiring agents and interested consumers, Washington used the sale and consumption of beauty products to teach black women to think as individuals. "The use and selection of cosmetics should be made on an individual basis," she explained, in which black women should consider their "own natural coloring

\footnotetext{
${ }^{60}$ Mme. Sara Spencer Washington, "World's Finest Beauty Preparations: Beauty Products and Their Use," (1922), 19.
} 
of skin and hair together with their texture." Cautioning female consumers to avoid the ideas of beauty marketed by white beauty agents, Washington reminded black women that "what is attractive on some model or even friend of yours, may possibly be unbecoming to you." More importantly, Washington insisted that there was a direct link between professional women and those who appealed to their individual inner beauty. "A woman who is smartly dressed is one who wears clothes to her physical background," she explained. In place of the degrading images of blackness popularized in Jim Crow renderings of black women, Washington instead persuaded black women to take pride in their natural features. "We did not determine our own individual features," she reminded black consumers, but "we can do much with cosmetics" to highlight the most desirable of those features. Indeed, as Washington explained, the APEX line of beauty products enabled African American women to take pride in the cosmetic advantages of blackness. Unlike blondes and brunettes, who were limited in their cosmetic choices, Washington explained that "those with brown skins, ranging from Cream to Copper are the most fortunate since they can wear cosmetics and clothes of almost any shades to advantage., ${ }^{, 61}$ In a Jim Crow marketplace that threatened to mock, ridicule, and exploit black consumers, Washington's assurances allowed beauty agents to take pride in their work and for black female consumers to take comfort in the promise of cultural expression and black beauty.

Despite her success as a beauty mogul and cultural trendsetter, Washington was unsatisfied with the available leisure outlets for respectable women at the Jersey shore. Using funds from her other successful enterprises, she would later finance the APEX

\footnotetext{
${ }^{61}$ Ibid., 2-3 . In the 1930s, APEX opened a school and distribution center in Johannesburg, South Africa, which sponsored an annual World Beauty Competition. Bantu World, "The Bantu World Beauty Competition," November 12, 1932.
} 
resort, a sprawling modern and inclusive vacation destination for black tourists that was outfitted with an assortment of amenities and choice accommodations. The palatial estate was regularly filled with area beauty agents who mingled with out-of-town guests to create a unique social network for striving black women. For those just starting out in the business, APEX Resort was an invaluable meeting place in which entrepeneurs acquainted themselves with new customers, future business partners, and potential financial backers. In a city in which white businessmen shaped patterns of labor and consumption, the developing social and economic marketplace created by Washington and her APEX consortium competed openly with the exclusive service sector of Atlantic City’s "boardwalk men.",62

The promotional messages of the APEX school were symbolic of a broader realization of the potential of black consumption. Washington, Ridley, and Walls turned the Jersey shore's consumer driven political economy into a respectable leisure district that competed openly with white businesses, promoting black entertainment and consumption without sacrificing respectability and prosperity. In an age in which northern employment patterns were spatially coded by racial customs and exclusionary public policies, the APEX business model offered successful female beauty agents the opportunity to advance socially and economically in spite of the political and cultural obstacles of Jim Crow.

Despite these social and economic advancements, the Jersey shore's respectable black men and women faced open competition from the proprietors of the region's low resorts and "cheap amusements" who threatened to undermine their hard-fought status

\footnotetext{
62 "Atlantic City Board of Trade Convention Bureau", Alfred M. Heston Collection, Atlantic City Free Public Library (1936); Atlantic City Tide, Vol. 3, No. 1 (1936).
} 
and prestige. Yet while many black civic reformers argued that such venues only sold sex and sin to vulnerable consumers, the proliferation of these low resorts were integral to the cultural and fraternal cohesion of Atlantic City's Northside nightlife. For many black tourists and seasonal laborers, the ability to enjoy simple pleasures and intimate sociability was often only found in the comfortable and safe confines of social clubs, poolrooms, dancing halls, and saloons. It was in these pleasure-seeking spaces where many working-class black consumers were free to create a personal style and cultural profile all their own. Unlike the voyeuristic venues of Atlantic City's main shopping district, the Northside's juke joints and pleasure dens took care of the rudimentary amusements and social desires of black consumers without the spectacle and legal maneuverings of Jim Crow's vigilant surveillance system. On hot summer nights, an untold number of public venues, including a great many "off the books operations" came alive to add to the allure and popularity of the Northside's exciting nightlife.

Like civil rights activists who pushed for a free consumer society, these anonymous bootleggers, pimps, and cardsharps pushed for an unregulated and guilt-free leisure marketplace that catered to the desires and expressive demands of black laborers. Among the most notorious venues were Charles Coleman's and Alexander Cook's gambling dens. Both men built a reputation as reckless and transient dealers whose checkered pasts often found them the targets of vice raids and consternation from local black leaders. To avoid detection from police and progressive-era moral reformers, many low spaces hid their profile inside respectable neighborhoods. Newspaper accounts from early police raids mention a "cottage" (a house of prostitution) run by a "Mrs. Burnett" 
and an interracial brothel run by a "Mrs. Collins." ${ }^{963}$ Unfortunately, little is known about these early venues. Because of the need to evade public detection and the Republican Party's inclination to protect them, the activities of these scandalous places were often buried with the men and women who ran them.

In devising economic and political strategies for social survival, black entrepreneurs and local religious leaders shifted their priorities from moral instruction to consumer-based remedies. They turned Atlantic City's Northside and Asbury Park's West End into incubators of productive work, fraternal comfort, and free cultural expression by boycotting the Jersey shore's white marketplaces. Rather than a symptom of black criminality, sexual deviancy, and urban decay, they promoted inclusive blackowned recreational venues as safe, secure, and healthy retreats that shielded patrons from the intrusive and degrading policies of Jim Crow. Although most black citizens postponed direct civil rights activism in favor of intraracial leisure, few saw themselves as apologists for white supremacy or Jim Crow accomodationists. Instead, they viewed their economic initiatives and political decisions as practical and potentially profitable solutions to political and economic problems that mass demonstrations and other forms of political protest had not fully eradicated. As John Cell has asked, "what was it like to be exposed, continually and relentlessly, to the double jeopardy of race and class discrimination in a segregated society?" ${ }^{64}$ To those unfamiliar and uncomfortable with the disapproving stares, quizzical glances, and hushed sneers of the Jersey shore's public leisure spaces, the racial politics of the boardwalk, beaches, and amusement venues

\footnotetext{
${ }^{63}$ Atlantic City Daily Union, July 25, 1907; Atlantic City Daily Union, July 29, 1907; Atlantic City Daily Union, August 25, 1907.

${ }^{64}$ John Cell, The Highest Stage of White Supremacy: The Origins of Segregation in South Africa and the American South (New York, 1982), 234-235.
} 
seemed to breed self-doubt rather than confident personal expression. For every black leader who admonished black tourists or championed civil rights, there were many others who worked independently to promote and build black businesses and entertainments venues of their own, hoping that while such ventures might not defeat Jim Crow, the availability of affordable consumer choice and fraternal comfort would prevent the cultural weight of segregation from crushing its most vulnerable citizens.

To compartmentalize the political loyalties of those who failed to participate in direct civil rights activities would be to deny African Americans the sophistication of political thought often afforded to white participants. Many northern blacks - both those who operated businesses and those who worked for whites - preferred to operate in the more comfortable political circles of friends and allies. Not only did combative civil rights politics not suit their personalities, many believed that direct political acts of rebellion obscured the urgent economic concerns that faced black communities, leaving many impoverished and financially dependent.

Those who lobbied for integrated leisure space and those who preferred to be left alone during their leisure hours both confounded the expectations white citizens constructed for African Americans after the Civil War. For black workers who sought an integrated leisure community, segregation represented the denial of their citizenship rights and a reminder that contemporary market-based rules did not protect the consumer rights of black workers and tourists with money to spend. For other black citizens, acts of civil disobedience threatened their economic security and prevented them from enjoying their leisure hours in peace. Yet both options reflected the black community's faith in a capitalist economy and a consumer culture to provide profitable work and peaceful 
relaxation. In the first two decades of the twentieth century, however, both of those dreams would come under frequent attack from law enforcement raiders and civic planners eager to redevelop and reposition the cultural and economic profile of the region. 


\section{Chapter 5: Cleaning Up Jim Crow, 1900-1920}

On September 13, 1909, the Atlantic City Daily Press declared "the lid went down on the tenderloin last night." ${ }^{\text {Th }}$ The first in a series of vice raids on black pool halls, juke joints, and other illegal gambling dens, the raids were greeted ambivalently by Republican Party city officials who worried that police intrusions into Atlantic City's black neighborhoods would upset racial harmony in the resort community and threaten the party's segregation pact with black leaders. When the raids turned to riots following an attempt by state detectives to close a gambling operation on Natter's Alley $-\mathrm{a}$ notorious street known for illicit amusements venues - efforts to police black communities became a referendum on the town's segregation policy. Under the direction of New Jersey State Prosecutor Clarence Goldenberg, three of the state's detectives attempted to close down the venue when local black residents and tourists blocked their entry. Shouting and jeering at the men as they made their way down the alley, the group soon gathered bats, clubs, and other weapons to ward off the vice detectives. When a plain-clothes white police officer shot into the crowd, black residents fired back, igniting a riot that ended when one of the detectives accidentally shot and wounded an unarmed woman watching the riot from her hotel balcony. Following the incident, all three of the white detectives were arrested and found guilty of disorderly conduct. ${ }^{2}$

In the days that followed, local black residents and Republican Party officials condemned Prosecutor Goldenberg and his detectives for "inciting a riot," while a coalition of "hotel men" and local Democrats blamed the city's law enforcement and

\footnotetext{
1 “Tenderloin Lid Goes Down,” Atlantic City Daily Press, September 13, 1909.

2 "Sleuths Released on Bail: Serious Charges Sequel to Riot," Atlantic City Daily Press, September 16, 1909; "Detectives Adjudged Guilty, But Sentence Was Suspended," Atlantic City Daily Press, September $18,1909$.
} 
political brass for coddling black vice owners and perpetuating a corrupt political culture where illegal black votes financed local Republican Party operations. ${ }^{3}$ As subsequent events in Atlantic City and Asbury Park would prove, the Goldenberg raid and riot became emblematic of efforts to solve the unforeseen political conflicts of segregation during the early 1900s. From 1885 to 1900, segregation policy at the Jersey shore rested on the containment of black leisure activities by excluding black tourists from the beaches, boardwalks, and local amusement venues, and isolating them in marginalized and unsanitary sections of town, in which seasonal work patterns, exclusionary social policies, and negligent landlords threatened backs' financial and political wellbeing.

Despite these challenging and discriminatory conditions, by the turn of the century, many African Americans managed to begin building a popular and modestly profitable black leisure district. Yet as blacks' settlement in Asbury Park and Atlantic City increased year after year, so did whites' discussions about how to manage and contain their consumer behavior and leisure activities. By 1900, it became clear to many white locals that segregation had entered a critical phase. Unable to halt the complaints of social reformers to clean up the area's vice districts, incapable of expanding commercially because of Jim Crow boundaries, and facing politically damaging inquiries from local Democrats about blacks' voting fraud, the region's merchants and local politicians undertook a sweeping re-evaluation of its segregation policy that highlights the politics of consumption during the early Jim Crow era.

In confronting these new realities, local officials shifted the priorities of the segregation debate from the region's beaches and boardwalks to the back alleys and redlight districts of the Jersey Shore's outlying areas. After 1900, maintenance of the color

\footnotetext{
3 “Goldenberg Says Office Carroll Fired First Shot,” Atlantic City Daily Press, September 16, 1909.
} 
line no longer proved as easy as separating the places that African Americans played from the places they lived. As public health concerns mounted, and tax revenue proved incapable of meeting the demands for modernized public utilities, moderate businessmen, progressive reformers, and even many prominent black residents set in motion plans to stem the tide of ghettoization, by promoting an ambitious program of municipal reforms that included some proposals to end residential segregation. ${ }^{4}$

The efforts of business owners, local politicians, and black activists to both consolidate and phase out the color line at the Jersey shore both qualify and contest historians' ideas about segregation during the progressive era. For many years, historians have noted the ways in which a new "managerial state" redirected civic and consumer life at the turn of the century. We now have a clearer picture, for example, of how government sponsored efforts to relocate vice venues and other "shadow economies" into African American neighborhoods became critical to criminalizing and compartmentalizing black consumer behavior in the early years of the "New Negro." Other more recent works have expanded this narrative by focusing on the activities of private capitalists, state governments, and federal regulators who worked in collusion

\footnotetext{
${ }^{4}$ While we know much about efforts to create black ghettos during the early twentieth century, we know less about white consumer driven movements to reposition and erase Jim Crow boundaries. See, Kenneth Kusmer, A Ghetto Takes Shape: Black Cleveland, 1870-1930 (Urbana, 1978); Alan Spear, Black Chicago: the Making of a Negro Ghetto, 1880-1920 (Chicago, 1967); Kimberly Phillips, Alabama North: AfricanAmerican Migrants, Community, and Working-Class Activism in Cleveland (Urbana, 1999); Francis M. Fortie, San Francisco's Black Community, 1870-1890: Dilemmas in the Struggle for Equality (San Francisco: R and E Associates, 1973); and Thomas Lee Philpot, The Slum and the Ghetto: Neighborhood Deterioration and Middle-Class Reform (New York, 1986).

${ }^{5}$ Regina Austin, “' Not Just for the Fun of It!': Government Restraints on Black Leisure, Social Inequality, and the Privatization of Public Space," Southern California Law Review, 71 (May, 1998); Marcy S. Sacks, “" To Show Who Was in Charge': Police Repression of New York City's Black Population at the Turn of the Twentieth Century," Journal of Urban History 31 (September 2005): 799-819; Khalil G. Muhammad, The Condemnation of Blackness: Ideas About Race and Crime in the Making of Modern Urban America (Cambridge, 2010); Kevin Mumford: Interzones: Black/White Sex Districts in Chicago and New York in the Early Twentieth Century (New York, 1997); William H. Tucker, The Science and Politics of Racial Research (Chicago, 1994); Kali N. Gross, Colored Amazons: Crime, Violence, and the Black Women in the City of Brotherly Love, 1880-1910 (Durham, 2006).
} 
with levee boards and homeowner's associations to undermine and confiscate black residential and commercial property and to constrain African-American pursuits of public and private recreation. ${ }^{6}$ The policing strategies undertaken by Atlantic City officials mirrored many of these trends, and foreshadowed later invasive tactics deployed elsewhere throughout the nation. ${ }^{7}$ Facing pressure from local Democrats and outside moral reformers, local police officers and Republicans attempted to root out black vice venues in Atlantic City through publicity raids and electoral reforms. Yet while these programs reinforced the popular narrative of black criminality, they did little to support the region's consumer-driven economy, appease moral reformers, or win friends from black political supporters.

In Asbury Park, white officials adopted an alternative approach. Business leaders addressed the problem of urbanization and the proliferation of illicit economies as an urgent public health crisis that threatened the moral and physical health of the resort town and blocked future commercial expansion efforts. Together with black supporters, annexationists used consolidation to indict the economic policies of James Bradley and to call for an end to segregation. Mirroring earlier struggles to define and position the color line in the 1870s and 1880s, annexation desegregation efforts in turn-of-the-century

\footnotetext{
${ }^{6}$ Andrew Kahrl's recent book, The Land Was Ours stands as the most complete history of these efforts to control black leisure in the Jim Crow South. Andrew Kahrl, The Land Was Ours: African American Beaches from Jim Crow to the Sunbelt South (Cambridge, 2012). Nathan Connally's forthcoming book, "A World More Concrete: Real Estate and Race in Jim Crow South Florida" will also no doubt prove invaluable in further tracing the connection between race, real estate, and recreation during the Jim Crow era. See, Nathan Connally, "By Eminent Domain: Race and Capital in the Building of An American South Florida," (Ph.D. diss., University of Michigan, 2008).

7 Thomas Sugrue, The Origins of the Urban Crisis: Race and Inequality in Postwar Detroit, (Princeton, 1996); Patricia Sullivan, Days of Hope: Race and Democracy in the New Deal Era, (Chapel Hill, 1996); Martha Biondi, To Fight and Stand: The Struggle for Civil Rights in Postwar New York City, (Cambridge, 2003); Gary Gerstle, Race and the Myth of the Liberal Consensus," Journal of American History, 82.2 (September, 1995); Arnold R. Hirsch, Making the Second Ghetto: Race and Housing in Chicago, 19401960 (Cambridge, 1983); Lizabeth Cohen, A Consumer's Republic: The Politics of Mass Consumption in Postwar America (New York, 2003).
} 
Asbury Park pitted local merchants and black residents against a small but vocal minority of white segregationists who feared that annexation would corrupt the political culture and social profile of the resort town. Casting segregationists as anti-growth reactionaries whose policies not only threatened the financial solvency of the resort, but also contributed to the spread of debilitating diseases, environmental dangers, and the proliferation of "low resorts" in its outlying and ungovernable areas, Asbury Park's annexation debate helps revise the one-dimensional image of northern style Jim Crow at the turn of the century. Although historians have more often examined efforts to criminalize and police black consumer behavior, the racial politics of annexation proved no less important in framing the public conversation over black leisure and shaping the politics of consumption and the political economy of race in the Jim Crow North.

In northern cities throughout the early 1900s, the trafficking of liquor and women and the widespread proliferation of gambling joints dominated urban consumer marketplaces. Although just as accessible in many modest cities, sprawling metropolitan areas like New York City, Chicago, Philadelphia, and Boston witnessed the public consumption of these illicit economies on an unprecedented scale. Facing pressure from progressive-era moral reformers, many city governments and private organizations engaged in a variety of reforms and state-sponsored initiatives throughout the first decade of the twentieth century to regulate and close the most scandalous venues. By the 1910s, temperance advocates had been widely successful in eradicating and re-routing the disreputable places from the main (and white) thoroughfares and marketplaces. The result of these reforms, however, did not officially end the availability of low resorts. From 
Chicago to Boston, juke joint operators, pool hall proprietors, pimps, and card-sharps set up shop in designated "interzones"- unregulated spaces located in many African American neighborhoods - where the popular businesses served an interracial clientele under the unspoken cloak of immunity. ${ }^{8}$

Few of these areas were more notorious than Atlantic City. The spiritual home of "booze, brauds, and gambling," the "world's playground" became, by the early 1900s, the go-to summer destination for those seeking simple pleasures and "something for nothing." ${ }^{.9}$ Atlantic City's unique appeal owed its reputation to the civic planners and resort promoters, who in tandem with local businesses and public officials had long marketed the idea that politics should serve consumption. By the mid-1890s, though, other political interests coalesced to redefine and reshape Atlantic City's scandalous public image. Not immune to the progressive era impulse to halt the racial impact of urbanization, Republican Party bosses found themselves increasingly attacked from moral reformers, muckrakers, and local Democrats who called on the city's power brokers to end the vice-ridden political economy that earned the city the unfortunate moniker of the "Sodom and Gomorrah of New Jersey." In a startling expose on Atlantic City's illicit venues, the Philadelphia Inquirer detailed an alarming comfort among city residents with "Atlantic City's Foul Blots." "The elements of low life have been allowed to gain what may be truthfully termed a dangerous ascendancy," the article declared, noting that particular leniency had been granted to brothels and prostitutes. ${ }^{11}$ "Notorious

\footnotetext{
${ }^{8}$ See Mumford, Interzones.

${ }^{9}$ Atlantic City Daily Press, April 10, 1902. In Something for the Nothing, Jackson Lears describes how gambling and other "games of chance" influenced turn-of-the-century discussions of political economy. T.J. Jackson Lears, Something for Nothing: Luck In America (New York, 2003).

${ }^{10}$ Atlantic City Daily Gazette, July 26, 1906.

11 “Atlantic City’s Foul Blots,” Philadelphia Inquirer, August 4, 1895.
} 
women are free to lure their victims to their gilded dens," in a city the Inquirer proclaimed in a follow-up story, where "everything goes, and it is not one better than Coney Island." ${ }^{12}$

Despite sporadic raids to wipe out the resort's disreputable venues, the proliferation of sex and sin seemed to be increasing in Atlantic City, while other northern cities were cracking down on their underground economies. By the middle of the decade, compliant hotel keepers, restaurant owners, and boardwalk operators abandoned the official party line and called on local officials to enforce New Jersey's Bishop's Lawforbidding the sale of alcohol on Sunday — and to close the thriving red-light districts in the city's "Northside" that threatened to undermine Atlantic City's white establishments. ${ }^{13}$ Home to the coastal community's black excursion district, the Northside soon became the public face of Atlantic City's vice problem. Republican Party bosses, headed by the notorious "Commodore" Louis Kuehnle, forged a political coalition with the Northside that action would not be taken to regulate or interfere with black businesses. ${ }^{14}$ The pact was central to the racial politics of consumption in the city, whereby blacks' support for party candidates and an understanding to keep away from designated "white beaches" and "cheap amusements" bought political autonomy for the Northside's developing black leisure industry.

In facing public pressure to end vice in the city, Atlantic City's ruling class confronted the prospect of losing their grip on the fragile and unofficial segregation

\footnotetext{
${ }_{12}^{12}$ Philadelphia Inquirer, August 5, 1895.

${ }^{13}$ Atlantic City Daily Union, July 26, 1906; Atlantic Review, July 25, 1907; Atlantic Review, August 1, 1907.

${ }^{14}$ For surveys on the political career of Commodore Louis Kuehnle and the history of Boss rule in Atlantic City, see esp. Charles E. Funnell, By the Beautiful Sea: The Rise and High Times of that Great American Resort, Atlantic City (New Brunswick, 1975); Martin Paulsson, The Social Anxieties of Progressive Reform: Atlantic City, 1854-1920 (New York, 1994); and Nelson Johnson, The Northside: African Americans and the Creation of Atlantic City (Medford, NJ, 2010).
} 
policy that divided the town (but ultimately kept the peace). Unwilling to crack down on noncompliant white establishments who bankrolled the party establishment and funded municipal improvements and commercial projects, the Commodore and his associates ambivalently adopted a hidden-hand approach to the problem of vice by singling out, through show raids and other staged law enforcement operations, the most notorious gamblers, bootleggers, and brothels of Atlantic City's Northside. As a show of support to their white supporters, the Commodore tipped off the city's white establishments, leaving the owners and proprietors of black-owned venues to face the brunt of police raids and indicting Jim Crow headlines alone. After Chief Eldridge raided and closed down Joshua Foreman's gambling joint on Artic Avenue, the local press angrily noted the shameful theatrics of the raid. "Even the police laughed at the farcical attempt," the paper explained, "at a general raid, and within an hour after the colored men were arrested, they had been bailed out by white politicians and all the dens opened up again." ${ }^{, 15}$ Black establishments raided during the summer of 1907 followed a similar pattern as police alerted white vice operators before condemning Joseph Ford and Bud Griffin's gambling houses. ${ }^{16}$

Although the raids were generally not injurious financially to those arrested and the Northside's respectable establishments were left alone, they assisted the public image of black leisure as dangerous, corrupt, and illegitimate. Whites who might only read the headlines or glance at the pictures showing a huge bar across the door of a black establishment would register a set of images that confirmed the racialized depictions of poverty, vice, and criminality in turn-of-the-century popular culture narratives of black

${ }_{16}^{15}$ Atlantic City Sunday Gazette, June 22, 1900.

${ }^{16}$ Atlantic City Daily Union, July 25, 1907; Atlantic City Daily Union, July 29, 1907; Atlantic City Daily Union, August 25, 1907. 
leisure communities. ${ }^{17}$ Even the most well-intentioned sociological surveys of the city's black community impacted and implicated the racial politics of the city. A 1912 representation of the Northside's slum districts by sociologist Margaret Brett stirred up the complaints of Democrats who pushed for a firmer boundary line separating the two communities and a more aggressive law enforcement policy. In attempting to explain the challenging seasonal employment patterns for service workers, Brett's findings instead confirmed the environmental fears that many hardline segregationists expressed about the need to condemn black leisure establishments in the Northside. One black employee of an Atlantic City hotel revealed to Brett that he often "accumulated boardwalk feet, nervous prostration and a plentiful lack of clean linen" that he took home with him everyday. Lacking "proper facilities" for tuberculosis and other debilitating diseases themselves," city residents, Brett explained, became a blighted spot on the resort city's public image and threatened the hygiene of respectable whites.

To Democrats, though, the most troublesome effects of these arrangements were that they left many of the city's black residents beholden to Republican Party officials who used the "slack seasons" to recruit needy residents onto its welfare rolls. In a city defined by consumption, the winter months meant that only the "steady" were kept on, while the city, Brett explained, was left to deal with "unpaid landlords and overtaxed city funds." The result, Democrats explained, was a corrupt political culture defined by the "cheerful philosophy" of black residents and Republican Party officials that it was the party's "duty to care for them." ${ }^{18}$ By highlighting the prevalence of black poverty and

\footnotetext{
${ }^{17}$ Atlantic City Daily Union, August 25, 1907.

${ }^{18}$ Margaret L. Bret, “Atlantic City: A Study in Black and White," Survey Magazine, Vol. 28 (1912). Published findings by New Jersey state officials in the 1930s uncovered that very little had changed in the Northside in the years following Bret's indicting survey. See, Interracial Committee: Department of
} 
unsanitary living conditions in the Northside, progressive reformers gave fodder to Democrats who complained about black voting fraud, and provoked fears in the minds of tourists and business owners who worried whether the immoral behavior and corruption that seemingly underwrote politics in the Northside would inflict economic and social damage to the city's main beach economies.

To Kuehnle and his Republican cronies, however, the purpose of the raids were not to support law and order, but to reclaim the promotional edge over a Progressive era moral constituency dedicated to reframing Atlantic City's politics and social profile. Mirroring Reconstruction-era promotional efforts that once claimed Atlantic City as the nation's preeminent middle-class resort, Kuehnle and his supporters used battles with temperance agents and segregationists to re-market the resort town as a glowing modern symbol of democratic consumption. "Atlantic City is one of the most remarkable manifestations of American life," officials declared to a Philadelphia Bulletin reporter. Defining the boardwalk and other consumer marketplaces as the "greatest illustration of 'Triumphant Democracy' in this country;" the Bulletin agreed, touting the popular marketplace as the only one of its kind where "the rich and the poor, the millionaire and the bootblack, the owner of the luxurious cottage, and the denizens of the excursion homes all meet on common ground." 19

For Republicans then, battles over vice venues and disagreements over the city's segregation policy revealed a fundamental difference over political economy. Kuehnle and his black supporters helped to popularize a new consumer-based governing

Institutions and Agencies, "Survey of Negro Life in New Jersey: Atlantic City," Community Report No. XIV (July 1932); "The Negro In New Jersey," Report of a Survey By The Interracial Committee of the New Jersey Conference of Social Work in Cooperation with the State Department of Institutions and Agencies, Alfred M. Heston Collection, Atlantic City Free Public Library.

${ }^{19}$ Philadelphia Bulletin, August 5, 1895. 
philosophy that identified individual and economic liberty with the freedom to consume. Democrats and moral reformers, on the other hand, scorned Atlantic City's free consumer society because it provided normally responsible citizens unregulated license to abandon the social protocol of industrial order by imbibing in the sinful desires and forbidden pleasures of illicit marketplaces. Holdovers from an older—but no less politically potent - free labor ideology, they found themselves in competition with a modern political culture increasingly beholden to consumer interests and interracial constituents.

Yet when Prosecutor Goldenberg and his detectives arrived in Atlantic City in the summer of 1909, the Republican Party's delicate Jim Crow pact was left exposed. Since the segregation pact was supposed to keep the peace, the Goldenberg riot unveiled to many opponents the extent to which extralegal maneuverings held the fragile peace together. Democrats used the fall-out from the riot to investigate the city's police department, and to inquire about the electoral activities of the Republican Party's African-American supporters. Charles White, the President of the Hotel Men's Association criticized Republicans and the city police department for openly undermining attempts to control black leisure activities. "The business element of this city, not those so-called reformers," White declared, "have been for some time trying to close the gambling houses in the negro section in the back part of town." Yet "we found," White explained, "that they were reopening one by one, and that all appeals to the police were in vain. ${ }^{20}$ The city’s police chief Malcomb Woodruff rebuffed charges of impropriety and cautioned Democrats to avoid inflaming additional racial tension by "making sensational issues at critical times. ${ }^{21}$ Yet, to White and his supporters, the government's response

\footnotetext{
${ }^{20}$ Atlantic Review, September 16, 1909.

${ }^{21}$ Atlantic City Evening Union, September 15, 1909.
} 
revealed the extent to which Republican Party officials would go to appease its relaxed Jim Crow policy and protect its black constituents.

Democrats had alleged black voter fraud in Atlantic City since 1892, when Democratic challenger William Riddle lost his bid for the state senate to Republican Party incumbent Samuel Hoffman. In the aftermath of the senatorial campaign, Riddle complained that Republicans had won only by "colonizing the colored Republicans in the city." At a senate investigation the following January, Riddle testified to multiple cases of election fraud, in which fictitious black residents cast votes for Republican Party candidates. $^{22}$ In addition, he claimed that other unidentified black voters were registered to vote in Philadelphia, Washington D.C. and "more distant points," and shipped in on Election Day to support Republican candidates. ${ }^{23}$ Following the 1909 riot, Democrats again attempted to link Republican Party political success to a systemic black voting scandal. Speaking to the Philadelphia North American, local Democrats explained that the "protection" Republicans provided to the Northside's black leisure district was "granted to the dives, not for money, but for votes." Noting the susceptibility of the local black population "to the blandishments of the gambling house and the resort of evil," officials linked this evil with even greater political offenses:

The balance of power rests with the Negro and the vicious white element in the Third Ward. This is Kuehnle's stronghold. It is the tenderloin of Atlantic City as McNichols' Tenth Ward is the tenderloin of Philadelphia. From this source, Kuehnle and his partners get the political strength to control the government of Atlantic City. From this lair marched the arrogant mobs of thugs and crooks,

\footnotetext{
${ }^{22}$ New Jersey State Senate, Protest, Testimony Taken before the Committee on Elections, and Reports of the Committee in the Matter of the Contest for State Senator of Atlantic County, New Jersey Between William Riddle, Contestant and Samuel D. Hoffman, Incumbent (Trenton, N.J, 1893), 2.

${ }^{23}$ Riddle v. Hoffman, 5.
} 
which the other night defied the law, broke into the regions of respectability, from which they hitherto been excluded, and ended a riot with potential murder. ${ }^{24}$

However, as Democrats scoured the Republican Party and degraded black leisure enterprises, they were also busy courting the Northside's votes in the fall of 1909. Having defected from Kuehnle's grip, prominent hotel owners did the party’s bidding, reminding black workers that it was they, and not the Commodore, who provided them work and steady pay. Charles White explained to the Atlantic Review that "every colored voter must realize that his welfare depends upon the welfare of the hotel men." As White and others explained, the black worker was no longer the cheap commodity they had once been, and hotels could easily secure "white waiters and waitresses just as cheaply as they could colored men." 25 To Democrats, the threats were designed to mark a clear distinction between the employment they provided and the welfare assistance that Republicans dolled out. As Lawrence McCoy explained, "This is the one time in local politics when it is a black man's fight as well," before hinting that black voters should support the men who profited from their labor over public officials who bought their dependency. ${ }^{26}$

African Americans in Atlantic City responded to these scandals and the larger political contest to win their vote along similar lines. Tired of being pawns for the Republican Party, and unwilling to support local Democrats who routinely appealed to conventional racist tactics to win support from segregationists, local black leaders in the Northside's Third Ward attempted to stake out a middle ground. Yet after they were

\footnotetext{
${ }^{24}$ Philadelphia North American, September 21, 1909. For additional allegations of election fraud, and in particular the buying of votes in Atlantic City's Northside, see, Atlantic City Daily Press, December 14, 1903; “The Rise and Fall of Kuehnle," Literary Digest, December 27, 1913.

${ }^{25}$ Atlantic Review, September 1, 1909.

${ }^{26}$ Atlantic Review, September 21, 1909.
} 
reprimanded by Republican officials for attempting to form an alternative wing of the party in 1906 and 1907, the Northside was left to either support the new coalition of hotelmen whose loyalties were suspect, or faithfully serve the Republican Party platform. $^{27}$

Throughout the fall campaign, a small contingent of black workers attempted to challenge the new Hotel Men's Association by threatening to strike for higher wages. Yet when many seasonal workers abandoned the campaign, the remaining few activists lost any political momentum they had gained. At a mass meeting in Fitzgerald's Hall, 500 black employees of the city's labor force voted to approve measures to support White and the "hotel men," declaring that "self preservation demands a duty to the merchants who give us employment." ${ }^{28}$ Rebuffed by Kuehnle and the Republicans and facing a newly formed and hostile Hotel coalition, those who refused to attend the meeting were left to offer little but scathing rhetorical rebuttals. A.L. Murray, who had attempted-alongside Gus Parker - to organize a "Colored Republican Club in 1906" and later the racially neutral Atlantic City Progressive Club" in the fall of 1909, challenged White and the Hotel Association's assertions that the black vote went to the highest bidder. "It has been said that the organization gives protection to the gamblers and saloonkeepers, and by this forces them to vote as they dictate," Murray declared, reiterating the now familiar charge of White and the Democrats. At the same time, he countered these insinuations by asking the hotel men whether "men and women who are employed are gamblers, thieves, and cutthroats because they support the organization that supports them?"29

${ }^{27}$ Atlantic City Sunday Gazette, September 19, 1909.

${ }^{28}$ Atlantic City Daily Press, September 13, 1909.

${ }^{29}$ Atlantic City Sunday Gazette, September 19, 1900. 
While Murray's claims struck at the hypocrisy of the city's Jim Crow political culture, they did little to influence public opinion or shape racial policy. Indeed, neither the outcome of the 1909 election nor the ouster and indictment of Louis Kuehnle by 1913 effectively challenged or reshaped the Republican Party's segregation pact with the Northside. Despite continued allegations from Democrats and other detractors, Kuehnle's successor and political heir Enoch "Nucky" Thompson continued the party's self-serving support of the city's segregation pact. However, the continuation of the policy does not effectively explain the long-term effects of the agreement. Although even Democrats eventually abandoned confiscation of black property in the name of political reform in the years to come, the political parameters of the Jim Crow system had effectively ended attempts to reform the social boundaries of the city's segregation policy. In a city in which politics served consumption, and where the unique system of boss rule limited alternative political possibilities, black residents and workers were socially resigned to bathe in the restricted area of sand and surf known as "Chicken Bone Beach" and forced politically to support Republican Party officials who offered the lesser of two evils.

Although he didn't know it at the time, the 1902 summer season would be James Bradley's last as leader of Asbury Park. As the twentieth century commenced, Bradley's once thriving resort had become unable to keep up with municipal improvements and was increasingly resistant to relaxing its temperance policies or to update its social standards. ${ }^{30}$ In the early months of 1903 , prominent merchants pressured Bradley to relinquish his authority and cede power to the newly formed Board of Trade Committee

\footnotetext{
${ }^{30}$ In opposing annexation, Bradley explained that he "opposed the construction of our streets" because the "cost of doing the work has become needlessly excessive." See, "Founder Bradley at Odds With Council," Asbury Park Evening Press, February 17, 1906.
} 
instituted to remarket and re-energize the shore town. By July 1903, they succeeded. Marking the occasion, New Jersey Governor Frank Murphy applauded the new regime for its plans to "outdo Atlantic City" and for "leaving off the old to put on the new.",31

The ouster of Bradley from power also meant that changes were coming to Asbury Park's segregation policy. Since 1893, Bradley's strict segregation ordinances had blocked efforts to develop and modernize the West End. To long-time businessmen and future developers, the Jim Crow plan, which made sense to many whites in the 1880 s and early 1890s, was now working against the financial and political interests of the resort park. By the early 1900s, developers discovered that they were unable to locate or secure available real estate under the town's present boundaries, and that tax revenue failed to finance the seemingly unending municipal improvements and sanitation concerns that mounted in the years that followed. To make matters worse, in order to preserve his control over Asbury Park's social character and maintain his paternalistic hold over the West End, Bradley routinely declined offers to commercialize Asbury Park and its surrounding districts. To modernize Asbury Park's infrastructure and racial policies, the resort town's new governing body set in motions plans to annex the territory known as "West Park" or the "West End"-Asbury Park's outlying areas "across the tracks" that were home to the town's 2,500 African Americans and Italian, Polish, Jewish, and Chinese residents and merchants.

In promoting its plans for consolidation in February 1906, the Board of Trade Annexation Committee indicted the economic and racial policies of the past. "Realizing that these effects retard the growth of realty, valuations, and desirability of that particular district as a residential section," the Committee explained that "we have adopted the

${ }^{31}$ Asbury Park Evening Press, July 6, 1903. 
proposition of annexation with an enthusiasm, which if met with the proper spirit by the residents of Asbury Park," could alleviate the pressing political and environment conditions of Asbury Park's "sister city." Calling on both white and black residents to free Asbury Park from its "swaddling clothes," committee members, in a subtle attack on Bradley's segregation policy, insisted that any plans to annex the West End should be pursued and "conducted on broad and liberal lines." ${ }^{" 32}$ In its proposal to city residents, the Board of Trade struck a particularly unique racial stance. As it attempted to drum up support for its expansive reorganization of government and industry, the decision to annex or not to annex Asbury Park's West End became tied to discussions about the fate of segregation in the resort city. Unlike Atlantic City's clean up efforts, which conformed to conventional patterns of racial control, Asbury Park's annexation proposals announced a subtle desire to confound and transcend Jim Crow practices in order to make "better representative government" work for consumption and protect environmental equality.

To the West End's prominent black residents and community leaders, the proposed annexation project was greeted with applause. Bradley's refusal to modernize Asbury Park's public utilities and infrastructure was compounded by the outright neglect of its outlying communities, which he considered to be incubators of illicit behavior protected by an ungovernable constituency. Mirroring some of Atlantic City's own slum districts, black residents and leaders worried that unless it was consolidated with Asbury Park, the West End would become just another underfunded and publicly ridiculed segregated black ghetto in the Jim Crow North. The support that annexation garnered among black residents of various classes explains the extent to which Asbury Park's segregation policy had matured since the 1880 s. Forced to enjoy their "beach days" in a

32 “Annexation Project is Renewed With Vigor," Asbury Park Evening Press, February 15, 1906. 
section of secluded sand known as the "Mud hole" - the dumping ground for Asbury Park's insufficient sewer system--black leaders and area residents made environmental reform, public health, and residential safety a cornerstone of their annexation support. "The annexation of West Park will solve the intricate sewage problem," Earl Stone, a resident and businessman in West Park, explained to reporters. Placing the West End's sanitation epidemic in humanitarian terms, a laundress residing in the West End explained to the Atlantic City Evening Press, "we are suffering in many ways for sewers to carry our dirty water as we now are compelled to throw on the ground and in the backyards, then inhale it, until the sun and the wind may take the smell away." And even then, she explained, "when there is not a heavy rain for a long time the ground becomes poisonous and our families must suffer."33

The West End's protests for municipal modernization and environmental advocacy drew upon a critical and developing component of the turn-of-the-century consumer movement that remade the politics of consumption through appeals to product safety and public health. Organizations like the National Consumer League (NCL) argued that consumers as well as governing bodies too often marketed and consumed items based on superficial qualifications such as personal style and cultural trends that ignored the broader public dangers and hazards of these seemingly innocent private choices. Calling on annexationists to make sanitation and prosperity one and the same, L.C. Hubbard acknowledged, "I am in favor of annexation, but not in a cowardly way...let us have sewers and better heath protection, which is the best wealth we can have." ${ }^{, 34}$ Like Hubbard, neighbors William Labaw and Walter T. Hubbard touted incorporation as the

\footnotetext{
33 “Annexation Needed," Asbury Park Evening Press, April 4, 1906.

34 "Meeting Tonight to Fix Boundary," Asbury Park Evening Press, February 17, 1906.
} 
"only solution of our defects and lack of modern conveniences," explaining that unless public health became a priority for local businesses, "better government, improved streets, and additional fire fighting abilities" would be incapable of keeping Asbury Park protected from an outbreak of influenza and small pox that routinely went untreated throughout West Park. ${ }^{35}$ Thus, like Progressive-era suffragists, black annexation supporters called on public officials to make the public's welfare an important criterion for crafting and implementing consumer policy. ${ }^{36}$

Agreeing with the West End's black community, Asbury's Board of Trade marketed public health as a cornerstone of its agenda to reform the resort's economic and segregation policy. "There can be no more forcible argument," annexation proponents asserted, "than the need of sanitation." To the more progressive members of the annexation committee, incorporation of the West End meant more than a gateway to commercial expansion. To several outspoken and influential members, it also meant a thorough cleansing and modernization of West Park. As one committee member succinctly explained, annexation would bring "purification" and the "expelling of all possible causes of diseases and epidemics." The result would be a healthier and more productive beach community that could reclaim its "reputation as a health resort;" a "safe place for women and children to live happily by the seashore, away from the heat of the cities and the atmosphere of contagion." Echoing those sentiments in an editorial to the local press, one white resident of Asbury Park chided skeptical voters to put aside their prejudices and elevate the mutual health of all involved. "Their cry is give us sewers and

\footnotetext{
${ }^{35}$ Asbury Park Evening Press, February 15, 1906, 4.

${ }^{36}$ Margaret Finnegan, Selling Suffrage: Consumer Culture and Votes for Women (New York, 1999).
} 
remove these unsanitary conditions," the citizen explained, before asking uncommitted whites whether "it is right that we should place the health of their children in danger?",37

Despite agreement on public health reform, the Committee's annexation plan was temporarily stalled when plans were implemented to include the West End's Springwood Avenue section. ${ }^{38}$ Although less prominent than Atlantic City's red-light districts, the section of gambling dens, pool halls, and juke joints that lined Springwood Avenue were no less notorious to city residents — both black and white-who worried about the moral and physical effects of ungovernable shadow economies. Board of Trade committee members made the case, as did African Americans, that annexation of all territory was necessary for government oversight and sanitation control. Exhibiting the racial condescension that accompanied most discussions of the Springwood avenue district, long-time white resident Dr. J. Turner Rose explained that any annexation agreement must include the divisive thoroughfare. Rose acknowledged that while the incorporated section would be difficult to control in its present condition, any proposed creation of a “Greater Asbury Park" would not be supported by many whites who no longer desired to "live with that thoroughfare continuing in its present condition under our nose.",39

Making segregation reform inseparable from issues of public health and consumer protection allowed annexationists to build a broader coalition of support among white residents. Like black proponents, white annexationists appealed to the new consumer maxim of "long-distance solidarity," which stressed an interconnected system of

\footnotetext{
37 “Township Powerless," Asbury Park Evening Press, March 30, 1906.

${ }^{38}$ The Board of Trade Annexation Committee proposed two boundaries for consolidation. The first proposal was one that included fixing the southern most boundary at Wesley Lake (thus including the Springwood Avenue district). A second option was soon proposed (and supported by James Bradley) that left out the Springwood Avenue district, and instead proposed annexing the northern most boundary at Mattison Avenue. See, "Sentiment in City Favors Annexation," Asbury Park Evening Press, February 16, 1906.

${ }^{39}$ Asbury Park Evening Press, February 17, 1906, 1.
} 
production and consumption. As many early-twentieth- century municipal reformers explained, citizens who entered venues dedicated to purchasable entertainmentespecially places known for providing indecent amusements—were no longer engaging in private decisions, but were instead making choices with public consequences. ${ }^{40}$ As one editorial to the local press noted, if "Springwood wasn't incorporated," it would be Asbury Park businesses and seasonal tourists who would "suffer the evils that breed there without having the power to apply corrective or punitary punishment." ${ }^{41}$ In a decision that shows the serviceable language of consumer politics, Asbury Park's Board of Trade Committee used this point to persuade white skeptics — including ardent segregationists - to consolidate Springwood Avenue. Adopting the language of Progressive-era liberals who believed in the "managerial state," as well as appealing to Reconstruction-era racial politics that stigmatized black consumer behavior as dangerous and corrupt, committee members asserted that "West Park needs a stern hand in its local government." They explained to doubters that "Asbury Park suffers because of the disorders of West Park." Yet they also reassured Asbury Park voters that the "plague spots could be wiped out within a year" if they supported present measures to annex and clean up the divisive neighborhoods and shopping districts. "The disorderly houses, the speak-easies, the houses which are made the nightly resort of the lowest classes of blacks," members explained, could be "wiped out of existence." ${ }^{42}$ As the committee's reasoning and rhetoric reveals, the flexible language of public health—as the various uses

\footnotetext{
${ }^{40}$ The idea of "long-distance solidarity" is taken from Lawrence Glickman's, Buying Power. In a sweeping and wide-ranging survey of consumer activism in America, Glickman asserts that consumer protestors and organizations popularized the notion that "actions taken at the cash register have a host of effects, most of them bound up in a dense and extensive web and chain." As this chapter argues, the racial consequences of these political ideals were most apparent in northern debates over segregation. Glickman, Buying Power, 3 ${ }^{41}$ Asbury Park Journal, March 20, 1906.

42 "Should Annex West Park," Asbury Park Evening Press, February 22, 1906.
} 
of the word "plague" indicate — could be adopted in the name of humanitarian cleanup efforts, as well as to promote the eradication of immoral market behavior.

To broaden additional support for annexation among both white and black voters, the Board of Trade Annexation Committee cited the commercial advantages of a unified government dedicated to free consumption. Citing the unavailability of land in the present boundaries of Asbury Park, as well as the moral benefits annexation would bring to black residents with the accompanying expansion, annexationist claims ran the gamut of turn-of-the-century imperialist ideology. Mirroring the rhetoric of Frederick Jackson Turner and other "open-door" contemporaries, annexation committee officials linked the future prosperity of the resort to its "capacity to build." As one official noted, "Being already built to capacity," Asbury Park “must by nature of its superior accommodations be always and only, with normally expanding territorial lines, the great business and residential section of the township." Citing statistical models that marked West Park's valuation at $\$ 1,042,250$, conservative committee estimates predicted an annual increase of 29 percent for the first two years, a total gain of $\$ 208,450.00 .{ }^{43}$ Others, like Board of Trade committee member George W. Pittinger were more optimistic. In a public forum hosted by the Board of Trade on February 16, 1906, Pittinger exclaimed that "the Annexation of West Park to Asbury Park will increase the property values of the former municipality 50 percent within a short time." ${ }^{44}$ Reflecting the developing speculative fever of the evening, Harry A. Borden, went even further, predicting that if West Park

\footnotetext{
43 “False Comparisons," Asbury Park Evening Press, February 21, 1906.

${ }^{44}$ Asbury Park Evening Press, February 16, 1906.
} 
followed the example of Spring Lake (a neighboring borough annexed to Neptune, New Jersey), black prospectors could foresee "the price of lots advanced 100 percent." 45

In anticipating the claims of some critics that annexation was nothing more than a self-serving mission that aimed to dominate the real estate and consumer markets of the region, prominent members of the committee like chairman J.L. Kinmonth offered the trickle down benefits of "one-government" rule. First, he explained that "it helps the business district to first concentrate and then expand by slow degrees... its wealth in the sections already improved and allow room for expansion to territory equally well situated." This would in turn, he pointed out, "expand property prices in the already improved areas and naturally expand property prices in the section to be improved." Thus, each section would share in the financial benefits of consolidation through increased consumption and rising property values. Asbury Park would be "proportionately benefited" by "concentrating and enlarging its wealth," and by comparison, so would the incorporated black communities by "sharing in the benefits of the compulsory expansion. ${ }^{46}$

In an editorial published in the local papers, one white resident, exclaiming the need to fulfill "our moral duty" applied the period's "white man's burden" logic to the case of Asbury Park. "Left to its own devices, drifting aimlessly like a ship without a rudder," the individual asked, "What would become of this little rejected settlement? How could finances be managed, how protected from its vicious class and how able to perpetuate even the semblance of government?" Drawing a line between the poverty and unfitness for self-government that many identified with West Park to the nation's

\footnotetext{
45 “Asbury Park Council Favors Annexation," Asbury Park Evening Press, February 20, 1906.

${ }^{46}$ Asbury Park Evening Press, February 15, 1906, 3.
} 
occupation of the Philippines, the editorial echoed the progressive reasoning of the period by asserting:

We can conceive of no argument based upon supreme selfishness and cruel indifference to the fate of these poor people strong enough to release this city from an obligation quite as imperative and absolutely parallel in the conditions to the taking of the Philippine's by the American government. It was the cry of moral duty that justified the transfer of the Philippines that justifies their (West Park) retention. ${ }^{47}$

Although few annexationists made such bold comparisons, the point was an instructive one. Progressive-era committee members, although united in their support of pubic health, commercial expansion, and a reconfiguration (and perhaps eradication) of the city's segregation policy, were of many minds when it approached the political character and racial destiny of black communities. While they rejected the explicitly racist maxims of some segregationist contemporaries - since such logic defied their claims that government and politics should serve consumption - they nonetheless revealed a virulent strand of racialist thinking that continued to view black political and economic autonomy as financially threatening, politically corrosive, and environmentally hazardous.

Among black residents in West Park, the financial possibilities of annexation were met with equal division. While they were united in their calls for public health reform, black residents and developers proceeded with cautious optimism when it came to commercial expansion and official political incorporation. To prominent businessmen and property owners, annexation offered the same benefits that white merchants foresaw. S.H. Labaw exclaimed to the local press that "as a property owner of West Park it is my opinion that annexation is the best thing that could happen for us. It will increase our

\footnotetext{
47 “Our Moral Duty,” Asbury Park Evening Press, March 25, 1906.
} 
property values and give us better government." William A. Berry agreed. Explaining the financial disparities between residents in Asbury Park and the West End, Berry pointed out that "property in Asbury Park has increased during the past few years, while in the township of Neptune, our values have remained practically the same for the past 20 years. If Asbury Park doesn’t want us we will incorporate as a borough.”

The West End's more skeptical residents, however, saw a more insidious plan at work. One cautious observer noted that while annexation might provide modernized facilities and public utilities to West Park, he feared that the expenses would be passed onto the West End's already feeble and insolvent economy. Instead of rising property values, he instead foresaw a scenario where "Asbury Park will arbitrarily require the above improvements, but they will assess the property of the annexed district accordingly, and will charge the assessment again the same." ${ }^{\prime 4}$ In an editorial published on March 31, 1906, businessman and property owner John H. Richardson echoed the skeptics by explaining, "I am against the project... because I see coming to that same people destitution, deprivation, and evacuation." Highlighting the tendency of wellintentioned whites to turn on black communities and businesses who could not meet the financial burdens of municipal reform elsewhere, Richardson noted that financial destitution would increase in West Park "because of the inability of my people to meet the financial demands it will bring it with it."49

As many black property owners and communities knew all too well, municipal reforms and commercial expansion projects were routinely accompanied with unforeseen financial obligations and hidden costs that often re-appropriated burdensome taxes and

\footnotetext{
${ }^{48}$ Asbury Park Evening Press, February 21, 1906, 4.

49 “Against Improvement,” John H. Richardson, Asbury Park Evening Press, 1906.
} 
regulations onto black constituents. Indeed, white opponents of annexation had openly promoted such requirements in citing their refusal to finance the welfare of the West End. They informed the Board of Trade Annexation Committee that any plan for consolidation would need to realign the tax system in order to pass along the financial responsibility to those citizens who needed the reforms most. In a meeting with the committee on February 19, 1906, councilman Jesse Minot voiced his reservations for a revenue-sharing plan under the proposed annexation proposal. Explaining that it would be a "financial burden" to the city," he noted that it should be "considered significant that sanitary and police protection — chief reasons for the union —were more required in the section left out than in the section sought to be taken in. ${ }^{, 50}$ To counter the optimistic property value estimates of the Board of Trade, James Bradley's secretary, William Wells, explained to the committee that any annexation proposal should consider the alternative boundary of Matison Avenue, which was valued at the present at $\$ 750,000.00$ compared to the proposed Springwood Avenue boundary, which carried a paltry $\$ 330,000.00$ valuation. Annexing the Springwood Avenue district, Wells argued, would thus "leave the burden of government upon Asbury Park" to finance a district with unending municipal deficiencies and heavy accompanying political and social risks.

In a debate that foreshadowed the desegregation battles of the 1950s and 1960s, the political contest over the financial responsibilities of annexation revealed competing visions of welfare, taxes, and the role of government. ${ }^{51}$ While progressive-minded annexationists believed that government should intervene to protect consumption by

\footnotetext{
50 "Annexation," Asbury Park Evening Press, February 20, 1906.

${ }^{51}$ Kenneth Durr, Behind the Backlash: White Working-Class Politics in Baltimore, 1940-1980, (Chapel Hill, 2003). Durr argues that competing visions of political economy, and not just racism, shaped the politics of desegregation during the Civil Rights era.
} 
adopting a revenue-sharing plan, white anti-annexationists believed the city's black residents should fund municipal improvements themselves. Black activists meanwhile threatened to withdraw support for annexation unless municipal resources were allocated according to public need. ${ }^{52}$ Fearing that squeamish annexation supporters would adopt burdensome tax proposals to appease skeptical whites, John Richardson threatened to "defend the rights of my race first" if vulnerable black residents were "sold out" by the city's change of heart. He cautioned black property owners not to idly dismiss the proposals of anti-annexationists, reiterating that "this effects each and every property owners where these improvements are to be made," including "the poor widow, the lone woman, and the old woman" whose livelihoods, he argued, should be considered just as important as the wealthy developers. ${ }^{53}$

While the Board of Trade, black activists, and skeptical councilmen like Jesse Minot debated the merits of resource allocation in mostly race neutral tones, other more ardently racialized arguments were put forth by James Bradley to retain the present Jim Crow boundaries and municipal structure. With his segregation policy under attack from both white progressives and black annexationists, Bradley took to the press to defend his scrutinized policies and to reject the proposed plans for incorporating the West End. In scathing attacks on the West End's political and social character, Bradley argued that not even annexation could contain or control the criminal element of Springwood Avenue, which if incorporated, would corrupt and corrode the moral foundations and profile of the resort. Ignoring the market-based arguments of earlier debates, Bradley's denounced the

\footnotetext{
${ }^{52}$ For a succinct survey on the racial politics of welfare during the first half of the twentieth century, see Linda Gordon, "Black and White Visions of Welfare: Women's Welfare Activism, 1890-1945," Journal of American History, 78.2 (September 1991): 559-590.

${ }^{53}$ Richardson, "Against Improvement."
} 
innate criminality of northern black culture. Reminding voters of the "shanties that have been erected in the Springwood Avenue district," Bradley exclaimed that "much disorder prevails in that locality." Although he acknowledged that many "respectable colored people reside there," the "percentage of disreputable people is much greater," he pointed out, "than in other colored communities in our state." Pass the resolution, he explained, and whites "could say goodbye to the present boom in Asbury Park real estate." 54

To traditional segregationists like Bradley, the scandalous vices of the West End were proof enough of the incompatibility of the two towns and the foolish utopian vision of annexation. While annexationists painted consolidation as a move to clean up the region's public health and strengthen the resort's consumer economy, Bradley argued that integration would devalue the profile of the resort, and worse, pave the way for a black political coalition that would work against the interests of consumption within the leisure economy. "To make the Wesley Lake brook (Springwood Avenue) the boundary line at the present time," he asserted, "is for Asbury Park to commit hari kari. ${ }^{, 55}$ However, for Bradley, who cared less than others did about consumer interests, the fear of black political power worried him most. In their rush to raise revenue and court the black vote, Bradley believed that annexationists were inviting the same level of corruption that drew scandalous headlines in Atlantic City. "To annex the objectionable district," he explained, "is to give over the destiny of Asbury Park to the scheming politicians who will secure this colored vote to serve his own ends regardless of how Asbury Park suffers." Worse still, the city would assume responsibility for the "largest number of

\footnotetext{
${ }^{54}$ James Bradley, “Annexation,” Asbury Park Evening Press, March 13, 1906. Bradley's letter to the editor denouncing the annexation proposal ran for two consecutive weeks in March and reappeared in May before the official vote.

55 "Bradley Opposes," Asbury Park Evening Press, March 5, 1906.
} 
colored voters pro rata of any city in the state of New Jersey," a fact compounded in Bradley's estimation since "the majority of the colored vote in Monmouth County is a purchasable article." Asbury Park Mayor Charles Atkins, and Bradley's ally in the fight against annexation agreed. Worried that consolidation would allow black residents to "elect a candidate for Mayor or councilman, thus taking the governing power away from Asbury Park," Mayor Atkins called on West Park to "prove that they can assimilate" socially before considering the Board of Trade's annexation plans. "Let them become a part of us in every sense of the word," he exclaimed, "and we can begin to seriously consider the advisability of consolidating the Springwood Avenue district." ${ }^{.56}$

Black activists and community residents responded to the racial rebukes of Bradley and Mayor Atkins by denouncing the narrative of criminality and political corruption popularized by the region's segregationist supporters. Longtime resident L.C. Hubbert pointed out that "for the last few years we have had three murders, six men shot, and three badly cut." Yet "none of the above crimes," he explained, "were committed by colored people. ${ }^{, 57}$ Citing the assertion of Bradley and others that the "colored voter was a purchasable lot," Reverend S.G. Kelly explained that the "day of foggyism is past. The negro thinks for himself and votes as he pleases regardless.... of 'long green' offered by our kind 'White Friends' in politics." ${ }^{58}$ More importantly, though, Hubbert and Reverend Kelly reminded whites that black voters were taxpayers too, according to Hubbert's estimates, in the range of "at least $\$ 100,000.00$ " per year, which justified financing the

\footnotetext{
56 "Atkins Opposed," Asbury Park Evening Press, March 8, 1906.

${ }^{57}$ L.C. Hubbert, "A Righteous Appeal," Asbury Park Evening Press, March 19, 1906.

${ }^{58}$ Rev. S.G. Kelly, "Will Vote Intelligently," Asbury Park Evening Press, March 28, 1906.
} 
construction of sewers and other sanitary improvements that were lacking in the West End. ${ }^{59}$

Fearing the potential political fall-out from their attempts to court segregationists, The Board of Trade Committee renewed their commitment to the progressive promises of sanitation reform and desegregation in the days and weeks leading up to the vote. To many members, the escalating racial tension of the debate revealed fundamental differences over the scope of government in a service economy. Indeed, the effort to provide better care for the well-being and health of a community's laboring classes was in keeping with a developing service culture reform movement taking place among prominent merchants at the turn of the century. Foreshadowing more expansive institutions of welfare capitalism in the late 1920s, leading retail moguls like John Wannamaker instituted a progressive system of welfare assistance to its workers that included health care benefits, educational assistance, and "legal wages." implications of this "service ideal" were most felt in Asbury Park, where several prominent business leaders dropped the marketplace conservatism of earlier segregation debates in favor of integration.

To mark this rhetorical departure, committee members stressed the interrelated political, economic and environmental interests of the two communities. Denouncing the "claims of pleaders" who pushed to maintain "existing lines of demarcation," Klinmonth called on other whites to reject even the "selfish view of annexation" that is asserted from

\footnotetext{
${ }^{59}$ Hubbert, "A Righteous Appeal," 4.

${ }^{60}$ In Land of Desire, William Leach describes the "elaborate employee welfare programs developed throughout the country" that were enacted by Macy's and Wanamaker's to maintain the "service ideal." William Leach, Land of Desire: Merchants, Power, and the Rise of the New American Culture (New York, 1993) 118-119, 121-122. The widespread intersection of consumption and welfare capitalism in the 1920s is addressed most notably by Liz Cohen in Making a New Deal. Lizabeth Cohen, Making a New Deal: Industrial Workers in Chicago, 1919-1930 (Cambridge, 1990).
} 
“certain alarmists who care nothing for the conditions of their neighbor's moral and physical welfare, provided everything looks smooth and rosy in their own locale." ${ }^{, 61}$ An editorial from an Asbury Park resident and voter agreed, noting that all residents, black and white, are "friends and neighbors and if perchance there are more spots to lift up to a higher and more acceptable purchase," then it was the duty of government to "let us be healers. ${ }^{, 62}$ Reiterating then, the rhetorical return of the common law culture of old, annexationists reworked the "greatest good for all" ideal to fit the developing therapeutic state maxims of a "uniform government for one people and one community," whose future prosperity and consumer interests, Klinmonth declared, are all "tied up in one thing, the resort business." Yet, in pursuing the ideal of a consumer democracy, Klinmonth and others rejected the notion that it should be accompanied through segregation; a system, he denounced, since it pitted "one man's plot of ground against any other man's plot." As recent experience had showed, "every case of dividing a territory," another resident declared, "has been unsatisfactory and an expensive experiment for the people."63

In rejecting the economic judgments that once justified segregation, annexationists also attacked the political fears of Bradley and others who cautioned whites to fear "the purchasable" tendencies of the West End voter. To Klinmonth and other progressive advocates of political integration, the notion that black voters would elect corrupt politicians who would then work against the interests of the popular resort were unfounded. "There is reason to believe, Klinmonth argued, "that West Park, realizing the destiny of the new city, would be proud to aid in the building of it,"

\footnotetext{
${ }^{61}$ J.L. Klinmonth, "United In Interest," Asbury Park Evening Press, March 27, 1906.

62 "Greatest Good to All," Asbury Park Evening Press, March 20, 1906.

${ }^{63}$ Asbury Park Evening Press, March 29, 1906, 4.
} 
especially since, he reminded whites, "its own well-being is wrapped up and controlled in the success of Asbury Park." Reiterating the progressive ideals of democratic consumption, Klinmonth acknowledged that the new system would work to ensure "that one man's vote is as good as another," explaining to critics that the town was not "reaching for fame as an exploitative resort." Remarketing Asbury Park as a "cosmopolitan city with no ruling class to the exclusion of the other," Klinmonth and the committee proposed a new era for the beach resort, one in which "more wealth and social standing is no more the badge of respectability and honesty of purpose in the community than the toil hardened and begrimed hands. ${ }^{.64}$

On May 16, 1906, the annexationists were finally victorious. In a landslide decision favoring consolidation, the West End was annexed to Asbury Park, officially ending residential and political segregation at the beach resort. While the New York Times applauded the efforts of the committee to put an end to the scandalous section of blackowned businesses on Springwood Avenue, the local papers expressed cautious optimism about future cooperation. A cartoon printed on the front page of the Asbury Park Journal featured a newly married couple with the words, "Now you're married, you must obey" printed below the picture. Indeed, while the annexation ruling brought sanitation and public health improvements to the West End, consolidation failed to completely eliminate the color line. In the 1920s, a hostile coalition of segregationists, backed by the Ku Klux Klan emerged in the beach town to temper and control black excursions to beaches and boardwalks, reminding many black locals that even the most dedicated of consumer economies could not completely repel the long-standing racial impulse to segregate.

\footnotetext{
${ }^{64}$ Klinmonth, "United In Interest,” 4.
} 
In both Atlantic City and Asbury Park, the new consumer politics of environmental reform and commercial growth enabled local African-American communities to protect their businesses, improve their neighborhoods, and in Asbury Park, officially end segregation. Intertwined in these debates were competing consumer and leisure discourses. Free consumer advocates advanced and protected the underground economy of leisure and advocates of consumer protection advanced a program of economic growth and environmental justice. Yet by tying economic rights to business development and municipal reform, black activists lost the struggle over integrated leisure and a consumer rights discourse framed around issues of access; a critical component of earlier Civil rights victories. For much of the next two decades, the segregation debate at the Jersey Shore would become one about the allocation of resources and consumer protection, rather than one about rights to space. The end of residential segregation, ironically, strengthened beachfront segregation. 


\section{Conclusion: "You'll Have to Use Your Imagination": Remembering Segregated Summers}

Each spring small crowds gather outside of the Cape May Community Center, a converted Jim Crow school that stands as one of the last physical remnants of the popular beach town's segregated past. Throughout the past fifteen years, revitalization efforts to preserve the building's structure have helped maintain its stature as an enduring symbol of African American life and history in the region. Those who have assembled outside the Community Center on this day, however, have not come to hear about the things that have been preserved, but instead to listen to those that have been discarded and forgotten. The 1940s-era maps in their hands attest to this fact, as visitors retrace with their fingers the popular resort's once profitable and vibrant black commercial district that has all but disappeared in the fifty years since segregation ended. When George Astor, a forty-year old High School teacher and volunteer steps in front of the group to begin the tour, he pauses to remind the group that "you'll have to use your imagination because the places I'll be mentioning on this tour are not there anymore." ${ }^{\prime 1}$ For those in attendance the remark is an all-too familiar reminder of the intense efforts of developers, civic planners, and local boosters to white-wash the uncomfortable remnants of Jim Crow's halcyon days following desegregation.

Like many Jim Crow districts at the Jersey Shore, Cape May’s black commercial district was torn down following the 1950s and 1960s Civil Rights movement. In its place, now stand summer mansions, shopping centers, and public parks. Gone are the hotels, pool halls, auditoriums, dime shops, and other amusement venues that attracted throngs of black visitors throughout the twentieth century, when Jim Crow regulated

\footnotetext{
${ }^{1}$ Dianna Marder, "Wave of the Past: A Once Segregated Shore," Philadelphia Inquirer, August 1, 2008.
} 
black tourists and workers to "their side" of the color-line. To those old enough to remember, these black commercial districts were more than just places to relax, catch a movie, or grab a bite to seat. They fed and nourished the east coast's most popular black entertaining district, and offered middle-class northern tourists a respite from the taunts and jeers that accompanied unauthorized visits to many "white spaces." It was in the nightclubs and concert halls during the 1920s, 1930s, and 1940s, where Paul Robeson, Count Basie, Duke Ellington, Ella Fitzgerald, and Billie Holiday brought ragtime, and later rhythm and blues to black travelers, and even many interested whites who dared to cross the color-line on summer nights. Following the all-night jam sessions, the era's famous black entertainers mingled with their star-struck audiences on "Chicken Bone Beach" in Atlantic City, and similarly regulated—yet unnamed—black beaches in Cape May, Ocean City, and Asbury Park. ${ }^{2}$

In the decades since segregation was repudiated, those spaces have been systematically eliminated, despite the best efforts of local black organizations to preserve their legacy. In beach town like Ocean City and Asbury Park, they now exist through anecdotal reminisces that recall the conventional racial attitudes that justified Jim Crow and the fraternal atmosphere that was created in response to them. As Henrietta Shelton, a founding member of the Chicken Bone Beach Historical Foundation, recalls, "There were no signs saying colored-only beach. You just knew your place." Richard Rimes, who grew up in Ocean City during Jim Crow remembers that as late as the 1950s "you were told to get off if you went on other beaches." Efforts to remember the racialized spacing

\footnotetext{
${ }^{2}$ Brett Norcross McCoy, "Links to Atlantic City's Past," Atlantic City Press, February 6, 1999; Atlantic City Press, 8, 1999. See also, Nelson Johnson, The Northside: African Americans and the Creation of Atlantic City (New York, 2010); Bryant Simon, Boardwalk of Dreams: Atlantic City and the Fate of Urban America (New York, 2004); Daniel Wolff, $4^{\text {th }}$ of July, Asbury Park: A History of the Promised Land (New York, 2004).
} 
of Jersey shore beaches remains imperative to preservationists because as Rimes' daughter Clarissa Grimes Price notes, "I would venture to say a lot of white people are not aware that there ever were black people in Ocean City."

Others, like Shelton, who grew up visiting Chicken Bone Beach, seek to highlight the collegial aspects that segregated beaches once engendered. In 1993, local activist Ted Primas, frustrated by the forgotten history of these popular spaces, penned a poem about Chicken Bone Beach that now serves as a mission statement for commemorating the beach's glory days. "Before the casinos, before the marches and sit-ins, when Jim Crow ruled the land and segregation was the word," Primas writes, "black folks weren't allowed to sit on any beach we chose, so Missouri Avenue Beach became the place for us." To Primas and many others, Chicken Bone Beach "was ours," a space where "black, brown, and beige bodies on burning sand and blue surf" helped create a "sound and rhythm all its own," a "cultural oasis—our place in the sun."4 The rich images of black northerners enjoying themselves in a time of racial discrimination, contradicts the traditional narrative, according to local historian Richlyn Goddard, "that the only reason black people came to Atlantic City was to work...They came for the amusements, to entertain, to swim, to fish.” Asked by a local reporter what she hoped visitors would take away from the Chicken Bone Historical Foundation, Henrietta Shelton explained, "That Atlantic City had a thriving and nice black middle-class."

Efforts to chronicle the history of racial discrimination and black independence highlight the dilemma of many post-Civil Rights revitalization efforts and preservation

\footnotetext{
${ }^{3}$ Marder, "Wave of the Past."

${ }^{4}$ Ted Primas, "Chicken Bone Beach," Alfred M. Heston Collection, Atlantic City Free Public Library (1993)

${ }^{5}$ McCoy, "Links to Atlantic City’s Past."
} 
campaigns. Like many urban centers in the 1960s, the history of desegregation at the Jersey shore was neither peaceful nor orderly. As Bryant Simon has astutely noted, in retrospect, "integration was that brief moment between segregation and retreat." Although only Asbury Park witnessed widespread race riots, efforts to integrate hotels, boardwalks, and amusement venues elsewhere along the shore proved to be just as volatile and occasionally violent. Led by local NAACP organizations, as well as more militant black activists, local citizens and out-of-town black visitors ended the region's unofficial practice of segregated movie theaters, lunch-counters, hotels, and beaches like Chicken Bone Beach. ${ }^{6}$ Yet, the end of segregation at these summer vacation sites also meant the destruction of profitable and popular black nightclubs and restaurants like the 500 Club and Club Harlem. Fond collective memories of these spaces thus compete with the discriminatory policies and rhetoric that made such spaces relevant and necessary.

In the decades since casinos remade Atlantic City and white flight left Asbury Park abandoned, remembering Jim Crow summers has been relegated to those volatile summer days in the 1960s and 1970s, when, according to many whites, black violence ruled the boardwalk and local officials learned to move beyond Civil Rights by disowning race. ${ }^{7}$ So, what then do these efforts to both remember and forget Jim Crow tell us about the creation and endurance of segregation in the post-Civil War North? Are they just another unwelcomed reminder about the prevalence of northern racism after the Civil War? As the past thirty years has proven, the denunciation of racism —in name if

\footnotetext{
${ }^{6}$ Simon, Boardwalk of Dreams, 112-117; Wolff, $4^{\text {th }}$ of July, Asbury Park.

${ }^{7}$ Jessica Adams, Wounds of Returning: Race, Memory, and Property on the Postslavery Plantation (Chapel Hill, 2007); Michele R. Boyd, Jim Crow Nostalgia: Reconstructing Race in Brownsville (Minneapolis, 2008); William H. Chafe, Raymond Gavins, and Robert Korstad, eds., Remembering Jim Crow: African Americans Tell About Life in the Segregated South (New York, 2001); James Loewen, How Free Is Free?: The Long Death of Jim Crow (Cambridge, 2009); Brian J. Norman, Neo-Segregation Narratives: Jim Crow in the Post-Civil Rights American Literature (Athens, 2010); and Renee C. Romano and Leigh Raiford, eds., The Civil Rights Movement in American Memory (Athens, 2006).
} 
not in fact - remains a triumphant component of the post-WWII Civil Rights legacy. Yet, for the black protestors and consumer activists who rejected the hidden-hand of Jim Crow in the late-nineteenth century, and again after WWII, such narrow commemorations threaten to perpetuate the less public - yet no less influential machinations and power of race in a post-Civil Rights "color-blind" America. ${ }^{8}$

Because it is difficult to quantify and render visible something as elusive as unofficial market relations - regulations which remain central to our economic heritagethe history of race remains reserved for the history of feelings and emotions, those outwardly visible signs that manifest themselves most recognizably in derogatory slurs, images, and physical acts that we can unwaveringly label "racist." This study, however, has tried to tell a more compelling and complicated narrative of race, recreation, and segregation. The history of Jim Crow at the Jersey shore during the Reconstruction period is one that weaves race into the political economy of the nation, and sets it in local public policy debates about markets and the rights of consumers.

Like the present day tour guides who use historic maps to creatively retrace the steps of a place and time lost to Jim Crow, we also have to think more creatively about race and consumer activism during Reconstruction. Doing so forces us to acknowledge an inconvenient truth about the history of American free enterprise that for much of the post-Civil War period was rarely free. ${ }^{9}$ While white Americans worked hard to associate blackness with miscegenation and criminality, a subtler and no less virulent form of white

\footnotetext{
8 Jacques Derrida, "Racism's Last Word," in Race, Writing, and Difference, eds., Henry Louis Gates, Jr. (Chicago, 1986); Henry Louis Gates, "Writing Race and the Difference It Makes," in Race, Writing, and Difference (Chicago, 1986); George Lipstiz, How Racism Takes Place (Philadelphia, 2011); Paul Gilroy, Against Race: Imagining Political Culture Beyond the Color Line (Cambridge, 2000).

9 Alfred D. Chandler, The Visible Hand: The Managerial Revolution in American Business (Cambridge, MA, 1971).
} 
supremacy emerged in places like Asbury Park and Atlantic City during the latenineteenth century to enable moderate businessmen to label black consumer activists as anti-capitalist. As the struggle to define segregation during the Gilded Age makes clear, and the efforts to erase Jim Crow in the 1970s highlight, the most creative and contentious contortions of race often reveal themselves in postemancipation societies. Recent memorials to black leisure and entrepreneurial ingenuity are a prescient reminder not just of a time when racial prejudice shaped public policy, but also about a time when black capitalists had to fight the overregulated hand of government-sponsored capitalism; when what today we call "crony capitalism" was once touted as a triumph of free choice and individual rights. Indeed, for all the efforts of scholars to differentiate between the two eras, both generations of liberal policymakers shared a commitment to manage racial change by embracing market-based solutions. Each reacted to a postemancipation political landscape, in which radical proposals were abandoned so they would not upset the collective psychology of a given electorate, or worse, threaten consumption. ${ }^{10}$

These historical realities highlight a central need to reevaluate how we determine the critical debates of the Reconstruction era. If we define Reconstruction as a southernfocused campaign that begins in 1865 and ends in 1877 then Reconstruction appears as a largely conservative and insignificant racist prelude to Plessy. If we define northern Reconstruction efforts as a set of laws and policies that sought to grapple with African Americans as citizens and workers, then again, we remain imbedded to the emotional pull of racism and are to prone to see northern fatigue and legal backtracking as unambiguous features of a conservative backlash. Reconstruction then, becomes defined as a failure to

\footnotetext{
${ }^{10}$ Howell S. Baum, Brown in Baltimore: School Desegregation and the Limits of Liberalism (Ithaca, 2010).
} 
implement a more progressive pubic policy, which in turn, further divorces the era's main philosophical debates from critical battles over political economy.

Conversely, if we approach the Reconstruction era as one equally determined by the struggle to define African Americans as consumers, we obtain a more enduring (but no less troubling) view of race and liberalism that is adaptive, sophisticated, and more applicable for the way we conceptualize and approach northern style Jim Crow in its more mature stages in the twentieth century. More importantly, making consumer politics central to Reconstruction history, rather than a feature of a subsequent and altogether different era we sometimes like to term the "Gilded Age," allows us to see how disagreements over the rights of consumers influenced Americans' attitudes towards government's role in the economy, notions of social mobility, and reactions towards African Americans' appeals for racial equality. In laying claim to a free consumer society, black civil rights activists forced white northerners to confront the contradictions of market capitalism, and later, to end segregation — in name if not in fact—by linking environmental equality with prosperity and consumer protection. These campaigns and the hostile white reaction they engendered from local political parties, tourists, and merchants, speak to the critical endurance of Reconstruction-era debates into the twentieth century. From 1865 to 1920 , the beach communities of the Jersey shore witnessed some of the most extraordinary experiments in interracial democracy undertaken by consumer activists, while also exhibiting the same disappointing tendencies and rhetoric displayed elsewhere throughout the nation to restrict integrated access to African-American consumers. These disputes over the public sphere and the rights of free individuals set the stage for a prolonged battle over the legality of 
segregation and the accessibility of the marketplace in northern leisure venues. White and black northerners created and contested public and social life during summers at the seashore as they synthesized the broader meaning of capitalism and the rights of consumers-elemental political concepts that were left unresolved in the wake of Reconstruction's_-and later segregation's_-collapse. 


\section{Bibliography}

\section{Primary Sources}

\section{Manuscript Collections:}

Atlantic City Public Library:

"Camden and Atlantic Railroad," Annual Report, 1873

"A Complete Guide to Atlantic City, (Philadelphia: Burk and McFetridge, 1885)

Carnewsworth, (Pseud.), Atlantic City: Its Early and Modern History,

(Philadelphia: Wm. C. Harris \& Co., 1868)

Alfred J. Heston Collection: African American Life in Atlantic City, NJ:

Audrey Hart Photograph Collection of the Black Community in Atlantic City

Apex Country Club Photograph Collection

"Charter of the Lighthouse Lodge of the Improved Benevolent Order of the Elks of the World (I.B.P.O.E. of W. )," February 12, 1900

Alfred J. Heston, Absegami: Annals of Eyren Haven and Atlantic City, 1609-1904, 2 vols. (Camden, NJ: Sinnickson Chew and Co., 1904

Alfred J. Heston, Industrial Handbook of Atlantic City, New Jersey, (Atlantic City: A.M. Heston and Company, 1889)

Margaret L. Brett, "Atlantic City: A Study in Black and White," Survey 28 (September 7, 1912): 723-26

Atlantic County Courthouse, Clerks Office and Surrogate Office:

Certificate of Incorporation, Book 5:9 (March 7, 1908), "Third Ward Colored

Organization"

Certificate of Incorporation, Book 5:9 (November 22, 1909), "Colored Workers'

League of the $3^{\text {rd }}$ Ward of Atlantic City"

Moorland-Spingarn Research Center, Howard University (Washington, D.C.)

Directory of Negro Hotels and Guest Houses in the U.S. (Washington, DC: U.S.

Dept. of Interior-National Park Service, 1939)

The Hotel Messenger, 2/6 (July 1918) (Harlem, NY: The National Association of Headwaiters)

New Jersey State Library:

Federal Writers Project, N.J. New Jersey Ethnic Survey, Box WK-2, Trenton, NJ:

New Jersey State Library, 1940:

"Creative Description of the North Side"

"Early Hotels in Atlantic City"

"Earning a Living in Atlantic City"

"The Negro in Business"

"The Negro Laborer"

"The Rise of the Negro Professional Man in Atlantic City" 
"The Rise of the Professional Man in Atlantic City

"Economic Shifts and Migratory Influences in Atlantic City"

"Education of Negroes in Atlantic City"

"History of the Negro Church in Atlantic City"

"Labor"

"Recreation"

"Social Agencies (in Atlantic City)"

Asbury Park Library:

"James A. Bradley and Asbury Park: A Biography and History," published under the Auspices of The Bradley Memorial Committee, 1921.

Monmouth County Historical Society:

James A. Bradley Papers (1830-1921). Processed by Lois A. Herr (1981)

"Reading the Future in Bradley Beach N.J." Postcard. New Jersey Collection, Monmouth College Library, Long Branch N.J., ND.

New York City Public Library:

Timothy Edward Howard, Excelsior, or, Essays on Politeness, Education, and the Means of Attaining Success in Life, Part I., (Baltimore: Kelly and Piet, 1868)

Our Manners at Home and Abroad: A Complete Manual on the Manners, Customs, and Social Forms of the Best American Society, (Harrisburg, Pennsylvania Publishing Company, 1883)

Currier and Ives Darktown Series (Photographs and Prints Division, Schomburg Center for Research in Black Culture

Newspapers/Periodicals:

Asbury Park Press

Atlantic City Daily Union

Atlantic City Sunday Gazette

Baltimore Afro American

Camden Courier

Daily Journal

Harper's Weekly

Hotel Monthly

Hotel World

Monmouth Democrat

Monmouth Inquirer

Philadelphia Bulletin

Philadelphia Call

Philadelphia Inquirer

Shore Press

The Baltimore Sun 
The Christian Record

The Red Bank Star

The New York Post

The New York Times

The New York Tribune

The Washington Post

The Baltimore Sun

Published Primary Sources:

Attwell, Ernest T. "Playgrounds for Colored America." Park International (November 1920).

Buchholz, Margaret Thomas. Shore Chronicles: Diaries and Travelers' Tales from the Jersey Shore, 1764-1955, eds. Harvey Cedars, NJ: Down the Shore Publishing, 1999.

Du Bois, W.E.B. "The Problem of Amusement.” Southern Workman, 26. September. 1897.

---- “The Color Problem of Summer.” Crisis, July 1929, 235, 250.

Nichols, Frank. "Social Hygiene and the Negro." Journal of Social Hygiene. (October 1929).

Woods, E.M. The Negro in Etiquette: A Novelty. St. Louis: Buxton and Skinner, 1899.

\section{Secondary Sources}

Abel, Elizabeth. Signs of the Times: The Visual Politics of Jim Crow. Berkeley: University of California Press, 2010.

Adams, Jessica. Wounds of Returning: Race, Memory, and Property on the Postslavery Plantation. Chapel Hill: University of North Carolina Press, 2007.

Agnevine, Erna. Roots of the Consumer Movement: A Chronicle of Consumer History in the Twentieth Century. Washington DC: National Consumers League, 1979.

Allnut, Brian E. "The Negro Excursions: Recreational Outings among Philadelphia African Americans, 1876-1926." Pennsylvania Magazine of History and Biography, 129. (January 2005).

Alsobrook, David E. “The Mobile Boycott of 1902: African American Protest or Capitulation." Alabama Review. (April 2003).

Andreasen, Alan R. The Disadvantaged Consumer. New York: Free Press, 1975.

Armstead, Myra B. Young. "Lord Please Don't Take Me in August”: African Americans in Newport and Saratoga Springs, 1870-1930. Urbana and Chicago: University of Illinois Press, 1999. 
Aron, Cindy. Working At Play: A History of Vacations in the United States. New York: Oxford University Press, 1999.

Austin, Regina. "Not Just for the Fun of It!: Governmental Restraints on Black Leisure, Social Inequality, and the Privatization of Public Space." Southern California Law Review, 71. (May 1998).

Ayers, Edward. The Promise of the New South: Life after Reconstruction. New York: Oxford University Press, 1992.

Bachin, Robing F. Building the South Side: Urban Space and Civic Culture in Chicago, 1890-1919. Chicago: University of Chicago Press, 2004.

Bederman, Gail. Manliness and Civilization: A Cultural History of Gender and Race in the United States, 1880-1917. Chicago and London: University of Chicago Press, 1996.

Bernstein, Iver. The New York City Draft Riots: Their Significance for American Society and Politics in the Age of the Civil War. New York: Oxford University Press, 1990.

Bethel, Elizabeth Raul. The Roots of African-American Identity: Memory and History in Free Antebellum Communities. New York: St. Martin's Press, 1997.

Bjelopera, Jerome P. City of Clerks: Office and Sales Workers in Philadelphia, 18701920. Urbana and Chicago: University of Illinois Press, 2005.

Blackwelder, Julia Kirk. Styling Jim Crow: African Americans Beauty Training during Segregation. College Station: Texas A\&M University Press, 2003.

Blair, William. Cities of the Dead: Contesting the Memory of the Civil War in the South, 1865-1914. Chapel Hill: University of North Carolina Press, 2004.

Blight, David W. Race and Reunion: The Civil War in American Memory. Cambridge: Harvard University Press, 2001.

Blumin, Stuart M. The Emergence of the Middle Class: Social Experience in the American City, 1760-1900. Cambridge: Cambridge University Press, 1989.

Bogen, David S. "Precursors to Rosa Parks: Maryland Transportation Cases between the Civil War and the Beginning of World War I." Maryland Law Review, 63. (2004).

Boskin, Thomas. Sambo: The Rise and Demise of an American Jester. New York: Oxford University Press, 1998. 
Bourdieu, Pierre. Outlines of a Theory of Practice. Cambridge: Cambridge University Press, 1977.

----- Distinction: A Social Critique of the Judgment of Taste. Cambridge: Harvard University Press, 1987.

Boyd, Michele R. Jim Crow Nostalgia: Reconstructing Race in Brownsville. Minneapolis: University of Minnesota Press, 2008.

Brooks, Daphne. Bodies in Dissent: Spectacular Performances of Race and Freedom, 1850-1910. Durham: Duke University Press, 2006.

Brown, Dona. Inventing New England: Regional Tourism in the Nineteenth Century. Washington, D.C.: Smithsonian Books, 1997.

Brundage, W. Fitzhugh. The Southern Past: A Clash of Race and Memory. Cambridge: Harvard University Press, 2005.

Bundles, A'Leila Perry. On Her Own Ground: The Life and Times of Madam C.J. Walker. New York: Scribner, 2001.

Bullard, Robert D. Dumping in Dixie: Race, Class, and Environmental Quality. Boulder, CO: Westview, 1990.

Bulmer, Martin. The Chicago School of Sociology: Institutionalization, Diversity, and the Rise of Sociological Research. Chicago: University of Chicago Press, 1984.

Burrows, John H. The Necessity of Myth: A History of the National Negro Business League, 1900-1945. Auburn: Hickory Hall Press, 1988.

Bushman, Richard L. The Refinement of America: Persons, Houses, Cities. New York: Vintage Books, 1992.

Butsch, Richard. For Fun and Profit: The Transformation of Leisure into Consumption. Philadelphia: Temple University Press, 1990.

Cell, John W. The Highest Stage of White Supremacy: The Origins of Segregation in South Africa and the American South. New York: Cambridge University Press, 1982.

Certeau, Michel de. The Practice of Everyday Life. Berkeley: University of California Press, 1984.

Chambers, Thomas. Drinking the Waters: Creating an American Leisure Clas at Nineteenth Century Mineral Springs. Washington, D.C.: Smithsonian, 2002. 
Chandler, Alfred D. The Visible Hand: The Managerial Revolution in American Business. Cambridge, MA: Harvard University Press, 1977.

Coates, James Roland. "Recreation and Sport in the African-American Community of Baltimore, 1890-1920.” Ph.D. diss., University of Maryland, College Park, 1991.

Cockrell, Dale. Demons of Disorder: Early Blackface Minstrelsy and Their World. Cambridge: Cambridge University Press, 1997.

Cocks, Catherine. Doing the Town: The Rise of Urban Tourism in the United States, 1815-1915. Berkeley: University of California Press, 2001.

Cohen, Lizabeth. A Consumers' Republic: The Politics of Mass Consumption in Postwar America. New York: Vintage Books, 2003.

Connolly, Nathan D.B. "By Eminent Domain: Race and Capital in the Building of an American South Florida.” Ph.D. diss., University of Michigan, 2008.

Cook, James W. The Cultural Turn in U.S. History: Past, Present, and Future. Chicago and London: University of Chicago Press, 2009.

Couvares, Francis. Remaking of Pittsburg: Class and Culture in an Industrializing City, 1877-1919. Albany: The State University of New York Press, 1984.

Dailey, Jane. Before Jim Crow: The Politics of Race in Postemancipation Virginia. Chapel Hill: University of North Carolina Press, 2000.

---- "Land, Labor, and Politics Across the Post-Emancipation South." Labor History, 44.4. (2003).

Danielson, Michael N. Profits and Politics in Paradise. Columbia: University of South Carolina Press, 1995).

Davis, Janet M. The Circus Age: Culture and Society Under the American Big Top. Chapel Hill: University of North Carolina Press, 2002.

Delaney, David. Race, Place and the Law, 1836-1948. Austin: University of Texas Press, 1998.

Derrida, Jacques. "Racism's Last Word," in Race, Writing, and Difference, ed., Henry Louis Gates Jr. Chicago: University of Chicago Press, 1986.

Diner, Steven J. A Very Different Age: Americans of the Progressive Era. New York: Hill \& Wang, 1998.

Dunier, Mitchell. Slim's Table: Race, Respectability, and Masculinity. Chicago: 
University of Chicago Press, 1992.

Edwards, Laura F. Gendered Strife and Confusion: The Political Culture of Reconstruction. Urbana and Chicago: University of Illinois Press, 1997.

----- The People and Their Peace: Legal Culture, and the Transformation of Inequality in the Post-Revolutionary South. Chapel Hill: University of North Carolina Press, 2009.

Elliott, Mark. Color-Blind Justice: Albion Tourgee and the Quest for Racial Equality from the Civil War to Plessy v. Ferguson. New York: Oxford University Press, 2008.

Enstad, Nan. Ladies of Love, Girls of Adventure: Working Women, Popular Culture, and Labor Politics at the Turn of the Century. New York: Columbia University Press, 1999.

Ernest, John. A Nation Within a Nation: Organizing African-American Communities Before the Civil War. Chicago: Ivan R. Dee, 2011.

Ernst, Daniel R. "Free Labor, the Consumer Interest, and the Law of Industrial Disputes, 1885-1900." American Journal of Legal History, 36. (Jan 1992).

Eyerman, Ron. Cultural Trauma: Slavery and the Formation of African American Identity. London: Cambridge University Press, 2001.

Ewen, Stuart. Captains of Consciousness: Advertising and the Social Roots of the Consumer Culture. New York: Basic Books, 2001.

Fabian, Ann. Card Sharps, Dream Books, Bucket Shops: Gambling in NineteenthCentury America. Ithaca: Cornell University Press, 1990.

Fahs, Alice. The Imagined Civil War: Popular Literature of the North and South, 18611865. Chapel Hill: University of North Carolina Press, 2001.

Fergin, Joe R. Living with Racism: The Black Middle-Class Experience. Boston: Beacon Press, 1994.

Field, Phyllis F. The Politics of Race in New York: The Struggle for Black Suffrage in the Civil War Era. Ithaca: Cornell University Press, 1982.

Fields, Barbara J. Slavery and Freedom on the Middle Ground: Maryland during the Nineteenth Century. New Haven and London: Yale University Press, 1985.

Finnegan, Margaret. Selling Suffrage: Consumer Culture and Votes for Women. New York: Columbia University Press, 1999. 
Fisher, Colin. "African Americans, Outdoor Recreation, and the 1919 Chicago Race Riot," in To Love the Wind and the Rain: African Americans and Environmental History, ed., Diane D. Glave and Mark Stoll. Pittsburgh: University of Pittsburgh Press, 2006.

Fitzgerald, Michael W. Urban Emancipation: Popular Politics in Reconstruction Mobile, 1860-1890. Baton Rouge: Louisiana State University Press, 2002.

Foner, Eric. Reconstruction: America's Unfinished Revolution: 1863-1877. New York: Harper \& Row, 1988.

----- Free Soil, Free Labor, Free Men: The Ideology of the Republican Party before the Civil War. New York: Oxford University Press, 1970.

Foster, Henry James "The Urban Experience of Blacks in Atlantic City, New Jersey: 1850-1915.” PhD diss., Rutgers, The State University of New Jersey, 1981.

Foster, Mark S. “" 'In the Face of Jim Crow': Prosperous Blacks and Vacations, Travel, and Outdor Leisure, 1890-1945.” Journal of Negro History, 84. (Spring 1999).

Fredrickson, George M. The Black Image in the White Mind: the Debate on AfroAmerican Character and Destiny, 1817-1914. New York: Harper \& Row, 1971.

Freund, David M.P. Colored Property: State Policy and White Racial Politics in Suburban America. Chicago: University of Chicago Press, 2007.

Funnell, Charles E. By the Beautiful Sea: The Rise and High Times of that Great American Resort, Atlantic City. New Brunswick: Rutgers University Press, 1975.

Gates, Henry Louis. "Writing Race and the Difference It Makes," in Race, Writing, and Difference. Chicago: University of Chicago Press, 1986.

Gatewood, Willard B. Aristocrats of Color: The Black Elite, 1880-1920. Fayetteville, University of Arkansas Press, 2000.

Geertz, Clifford. Negara: The Theatre State in Nineteenth Century Bali. Princeton: Princeton University Press, 1980.

Giesberg, Judith Ann. Army At Home: Women and the Civil War on the Northern Homefront. Chapel Hill: University of North Carolina Press, 2009.

Gilfoyle, Timothy J. "White Cities, Linguistic Turns, and Disneylands: The New Paradigms of Urban History." Reviews in American History, Vol. 26. (March 1998). 
Gillette, William. Retreat from Reconstruction, 1869-1879. Baton Rouge: Louisiana State University Press, 1979.

Gillette Jr., Howard. Between Justice and Beauty: Race, Planning, and the Failure of Urban Policy in Washington, D.C. Baltimore: Johns Hopkins University Press, 1995.

Gilmore, Glenda. Gender and Jim Crow: Women and the Politics of White Supremacy in North Carolina, 1896-1920. Chapel Hill: University of North Carolina Press, 1996.

Gilroy, Paul. Against Race: Imagining Political Culture Beyond the Color Line. Cambridge: Harvard University Press, 2000.

David Gellman and David Quigley. Jim Crow New York: A Documentary History of Race and Citizenship, 1777-1877. New York: New York University Press, 2003.

Goddard, Richlyn F. "Three Months to Hurry, Nine Months to Worry": Resort Life for African Americans in Atlantic City, 1854-1940." PhD diss., Howard University, 2001.

Goldberg, David Theo. Racist Culture: Philosophy and the Politics of Meaning. Cambridge: Blackwell Publishers, 1993)

----- The Threat of Race: Reflections on Racial Neoliberalism. Cambridge: Blackwell Publishers, 2009.

Gordon, Linda. “Black and White Visions of Welfare: Women's Welfare Activism, 1890-1945." Journal of American History, 78, 2. (September 1991).

Glickman, Lawrence. Buying Power: A History of Consumer Activism in America. Chicago: Chicago University Press, 2009.

----- A Living Wage: American Workers and the Making of Consumer Society. Ithaca: Cornell University Press, 1997.

Graham, Lawrence Otis. Our Kind of People: Inside America's Black Upper Class (New York: HarperCollins, 1999.

Greason, Walter D. "From Village to Suburb: Race Politics and Economics in Monmouth County, NJ, 1890-1900.” PhD diss., Temple University, 2004.

Greenberg, Dolores "Reconstructing Race and Protest: Environmental Justice in New York," Environmental History, 5. (2000).

Gross, Ariela. What Blood Won't Tell: A History of Race on Trial in America. 
Cambridge: Harvard University Press, 2008.

Hahn, Stephen. A Nation Under Our Feet: Black Political Struggles in the Rural South from Slavery to the Great Migration. Cambridge: Harvard University Press, 2003.

Hale, Grace Elizabeth. Making Whiteness: The Culture of Segregation In the South, 1890-1940. New York: Vintage Books: A Division of Random House, 1999.

Halttunen, Karen. Confidence Men and Painted Women: A Study of Middle-Class Culture In America, 1830-1870. New Haven and London: Yale University Press, 1982.

Hamilton, Kenneth Marvin. Black Towns and Profit: Promotion and Development in the Trans-Appalachian West, 1877-1915. Urbana: University of Illinois Press, 1991.

Harris, Leslie M. In the Shadow of Slavery: African Americans in New York City, 16261863. Chicago: University of Chicago Press, 2003.

Hartman, Saidiya V. Scenes of Subjection: Terror, Slavery, and Self-Making in Nineteenth-Century America. New York: Oxford University Press, 1997.

Hazzard-Gordon, Katrina. Jookin': The Rise of Dance Formations in African-American Culture. Philadelphia: Temple University Press, 1990.

Hirsch, Arnold R. Making the Second Ghetto: Race and Housing in Chicago, 1940-1960 Cambridge: Cambridge University Press, 1983.

Hodges, Graham Russell. Slavery and Freedom In the Rural North: African Americans in Monmouth County, New Jersey, 1665-1865. Madison, WI: Madison House Publishers, 1997.

Holt, Sharon Ann. Making Freedom Pay: North Carolina Freedpeople Working for Themselves, 1865-1900. Athens: University of Georgia Press, 2000.

Horowitz, Daniel. The Morality of Spending: Attitudes Towards the Consumer in America, 1875-1940. Chicago: University of Chicago Press, 1992.

Hoy, Suellen. Chasing Dirt: The American Pursuit of Cleanliness. New York: Oxford University Press, 1995.

Hunter, Tera W. To 'Joy My Freedom: Southern Black Women's Lives and Labors after the Civil War. Cambridge: Harvard University Press, 1997.

Hurley, Andrew. Environmental Inequalities: Class, Race, and Industrial Pollution in Gary, Indiana, 1945-1980. Chapel Hill: University of North Carolina Press, 1995.

Jacobson, Matthew Frye. Barbarian Virtues: The United States Encounters Foreign 
Peoples at Home and Abroad, 1876-1917. New York: Hill and Wang, 2001.

Johnson, Nelson. The Northside: African Americans and the Creation of Atlantic City. New York: Plexus Publishing, 2010.

Josephson, Matthew. The History of the Hotel and Restaurant Employees and Bartenders International Union, AFL-CIO. New York, 1955.

Kahrl, Andrew W. The Land Was Ours: African American Beaches from Jim Crow to the Sunbelt South. Cambridge: Harvard University Press, 2012.

---- "The Political Work of Leisure: Class, Recreation, and African American Commemoration at Harpers Ferry, West Virginia, 1881-1931.” Journal of Social History, 42. (2008).

---- “ “The Slightest Semblance of Unruliness: Steamboat Excursions, Pleasure Resorts, and the Emergence of Segregation Culture on the Potomac River." The Journal of American History, 94.4, (March, 2008).

Kantrowitz, Stephen. " 'Intended for the Better Government of Man”: The Political History of African American Freemasonry in the Era of Emancipation." The Journal of American History, 96.4. (March 2010).

Kasson, John F. Rudeness and Civility: Manners in Nineteenth-Century Urban America. New York: Hill \& Wang, 1990.

----- Amusing the Millions: Coney Island at the Turn of the Century. New York: Hill and Wang, 1978.

Kelly, Blair L. M. Right to Ride: Streetcar Boycotts and African American Citizenship in the Era of Plessy v. Ferguson. Chapel Hill: University of North Carolina Press, 2010.

Kelley, Robin D.G. Race Rebels: Culture, Politics, and the Black Working Class. New York: Free Press, 1994.

Klarman, Michael J. From Jim Crow to Civil Rights: The Supreme Court and the Struggle for Racial Equality. New York: Oxford University Press, 2004.

Klingle, Matthew. "Fair Play: Outdoor Recreation and Environmental Inequality in Twentieth Century Seattle," in The Nature of Cities, ed. Andrew Isenberg. Rochester, NY: University of Rochester Press, 2006.

Kusmer, Kenneth. A Ghetto Takes Shape: Black Cleveland, 1870-1930. Urbana: University of Illinois Press, 1976. 
Ronald M. Labbe` and Jonathan Lurie, The Slaughterhouse Cases: Regulation, Reconstruction, and the Fourteenth Amendment, abr. eds. Lawrence: University Press of Kansas, 2005.

Lears, T.J. Jackson. No Place of Grace: Antimodernism and the Transformation of American Culture, 1880-1920. New York: Pantheon Books, 1981.

---- $\quad$ Fables of Abundance: A Cultural History of Advertising in America. New York: Basic Books, 1994.

----- Something for Nothing: Luck in America. New York: Viking, 2003.

----- $\quad$ eds., The Culture of Consumption: Critical Essays in American History, 18801980. New York: 1983.

Lee, Ericka. At America's Gates: Chinese Immigration During the Exclusion Era, 18821943. Chapel Hill: University of North Carolina Press, 2003.

Levine, Lawrence W. Black Culture and Black Consciousness: Afro-American Folk Thought From Slavery to Freedom. New York: Oxford University Press, 1977.

---- High Brow/Low Brow: The Emergence of Cultural Hierarchy in America. Cambridge: Harvard University Press, 1990.

Litwack, Leon T. North of Slavery: The Negro in the Free States, 1790-1860. Chicago: University of Chicago Press, 1961.

----- Been In the Storm Too Long. New York: Random House, 1979.

Lipsitz, George. How Racism Takes Place. Philadelphia: Temple University Press, 2011.

Loewen, James. How Free is Free?: The Long Death of Jim Crow. Cambridge: Harvard University Press, 2009.

Lofgren, Charles. The Plessy Case: A Legal-Historical Interpretation. New York: Oxford University Press, 1988.

Lopez, Ian Haney. White by Law: The Legal Construction of Race. Cambridge: Harvard University Press, 2006.

Lott, Eric. Love and Theft: Blackface, Minstrelsy and the American Working Class. New York: Oxford University Press, 1993.

Lorini, Alessandra. Rituals of Race: American Public Culture and the Search for Racial Democracy. Charlottesville and London: University of Virginia Press, 1999. 
Manning, Chandra. What This Cruel War Was Over: Soldiers, Slavery, and the Civil War, (New York: Vintage Books, 2007.

Marchand, Roland. Advertising the American Dream: Making Way for Modernity, 19201940. Berkeley: University of California Press, 1985.

Masur, Kate. An Example for All the Land: Emancipation and the Struggle Over Equality in Washington, D.C. Chapel Hill: University of North Carolina Press, 2010.

----- "A Rare Phenomenon of Philological Vegetation": The Word "Contraband" and the Meanings of Emancipation in the United States." Journal of American History, 93.4. (March, 2007).

McGerr, Michael. A Fierce Discontent: The Rise and Fall of the Progressive Movement in America. Oxford: Oxford University Press, 2003.

August Meier and Elliot Rudwick, "The Boycott Movement against Jim Crow streetcars in the South, 1900-1906." in Along the Color Line: Explorations in the Black Experience. Urbana: Univesity of Illinois Press, 1976.

----- "Negro Boycotts of Jim Crow Streetcars in Tennessee." American Quarterly, 21 (Winter 1969).

Melish, Joanne Pope. Disowning Slavery: Gradual Emancipation and "Race" in New England, 1780-1860. Ithaca and London: Cornell University Press, 1998.

Mills, Charles W. The Racial Contract. Ithaca: Cornell University Press, 1997.

Mitchell, Michelle. Righteous Propagation: African Americans and the Politics of Racial Destiny after Reconstruction. Chapel Hill: University of North Carolina Press, 2004.

Mitchell, Thomas W. "From Reconstruction to Deconstruction: Undermining Black Landownership, Political Independence, and Community through Partition Sales of Tenancies in Common." Northwestern University Law Review, 95 (Winter 2001.

Mjagkij, Nina. Light in the Darkness: African Americans and the YMCA, 1852-1946. Lexington: University Press of Kentucky, 1994.

Montgomery, David. Beyond Equality: Labor and the Radical Republicans, 1862-1872. New York: Vintage Books, 1967.

Muhammad, Khalil G. The Condemnation of Blackness: Ideas about race and Crime in the Making of Modern Urban America. Cambridge: Harvard University Press, 2010. 
Mumford, Kevin. Interzones: Black/White Sex Districts in Chicago and New York in the Early Twentieth Century. New York: Columbia University Press, 1997.

Nadell, Martha Jane. Enter the New Negroes: Images of Race in American Culture. Cambridge: Harvard University Press, 2004.

Nasaw, David. Going Out: The Rise and Fall of Public Amusements. Cambridge: Harvard University Press, 1999.

Neely, Jr., Mark E. The Boundaries of American Political Culture in the Civil War Era. Chapel Hill: University of North Carolina Press, 2005.

Nelson, William E. The Fourteenth Amendment: From Political Principle to Judicial Doctrine. Cambridge: Harvard University Press, 1988.

Norman, Brian J. Neo-Segregation Narratives: Jim Crow in the Post-Civil Rights American Literature. Athens: University of Georgia Press, 2010.

Novak, William. The People's Welfare: Law and Regulation in Nineteenth Century America. Chapel Hill: University of North Carolina Press, 1996.

Ownby, Ted. Subduing Satan: Religion, Recreation, and Manhood in the Rural South, 1865-1920. Chapel Hill: Univesity of North Carolina Press, 1990.

Peel, Mark. "On the Margins: Lodgers and Boarders in Boston, 1860-1900." Journal of American History, 72. (1986).

Peiss, Kathy. Cheap Amusements: Working Women and Leisure in Turn-of-the-Century New York. Philadelphia: Temple University Press, 1986.

Philpot, Thomas Lee. The Slum and the Ghetto: Neighborhood Deterioration and Middle-Class Reform, 1880-1930. New York: Oxford University Press, 1978.

Pietilo, Antero. Not In My Neighborhood: How Bigotry Shaped a Great American City. Chicago: Ivan R. Dee, 2010.

Quigley, David. The Second Founding: New York City, Reconstruction, and the Making of American Democracy. New York: Hill and Wang, 2004.

Pascoe, Peggy. "Miscengenation Law, Court Cases, and Ideologies of Race in Twentieth Century America. Journal of American History, 83, 1. (June 1996).

Paulsson, Martin. The Social Anxieties of Progressive Reform: Atlantic City, 1854-1920. New York: New York University Press, 1994. 
Pike, Helen C. Asbury Park's Glory Days: The Story of An American Resort. New Brunswick, NJ: Rutgers University Press, 2005.

Pivar, David J. Purity Crusade: Sexual Morality and Social Control, 1868-1900 Westport, Conn: Grenwood Press, 1973.

Rabinowitz, Howard. Race Relations in the Urban South, 1865-1890. Athens: University of Georgia Press, 1978.

Reiss, Benjamin. The Showman and the Slave: Race, Death, and Memory in Barnum's America. Cambridge: Harvard University Press, 2010.

Rhodes, Chip. "Writing up the New Negro: The Constitution of Consumer Desire in the Twenties." Journal of American Studies, 28. (1994).

Richardson, Heather Cox. The Death of Reconstruction: Race, Labor, and Politics in the Post-Civil War North, 1865-1901. Cambridge: Harvard University Press, 2001.

Rodrigue, John C. Reconstruction in the Cane Fields: From Slavery to Free Labor in Louisiana's Sugar Parishes, 1862-1880. Baton Rouge: Louisiana State University Press, 2000.

Roediger, David R. The Wages of Whiteness: Race and the Making of the American Working-Class. New York: Verso, 1991.

Renee C. Romano and Leigh Raiford, eds. The Civil Rights Movement in American Memory. Athens: University of Georgia Press, 2006.

Rooks, Noliwe. Hair Raising: Beauty Culture and African American Women. New Brunswick: Rutgers University Press, 1996)

Rosenzweig, Roy. Eight Hours For What We Will: Workers and Leisure In An Industrial City, 1870-1920. Cambridge: Harvard University Press, 1983.

Rothman, Hal. Devil's Bargain: Tourism in the Twentieth Century American West. Lawrence: University Press of Kansas, 2000.

Ryan, Mary P. Civic Wars: Democracy and Public Life in the American City during the Nineteenth Century. Berkeley: University of California Press, 1997.

Rymer, Russ. American Beach: A Saga of Race, Wealth, and Memory. New York: HarperCollins, 1998.

Sacks, Marcy S. “'To Show Who was in Charge': Police Repression of New York City's Black Population at the turn of the Twentieth Century." Journal of Urban History, 31. (September 2005). 
Samson, Peter Edward. 'The Emergence of a Consumer Interest in America, 1870-1930. PhD diss., University of Chicago, 1980.

Savage, Kirk. Standing Soldiers, Kneeling Slaves: Race, War, and Monument in Nineteenth Century America. Princeton: Princeton University Press, 1997.

Saville, Julie. The Work of Reconstruction: From Slave Labor to Wage Labor in South Carolina, 1860-1870. Cambridge and New York: Cambridge University Press, 1994.

Saxton, Alexander. The Rise and Fall of the White Republic: Class, Politics, and Mass Culture in Nineteenth-Century American. London and New York: Verso, 1990.

Scasz, Andrew. Shopping Our Way to Safety: How We Changed from Protecting the Environment to Protecting Ourselves. Minneapolis: University of Minnesota Press, 2007.

Scott, Rebecca J. "Public Rights, Social Equality, and the Conceptual Roots of the Plessy Challenge.” Michigan Law Review, 106, 777 (March 2008).

Schudson, Michael. Advertising, the Uneasy Persuasion: Its Dubious Impact on American Society. New York: Basic Books, 1984.

Shaw, Stephanie J. What a Woman Ought to Be and to Do: Black Professional Women Workers during the Jim Crow Era. Chicago: University of Chicago Press, 1995.

Skotnes, Andor. "Buy Where You Can Work: Boycotting for Jobs in African American Baltmore, 1933-1944.” Journal of Social History, 27. (1994)

Smith, C. Fraser. Here Lies Jim Crow: Civil Rights in Maryland. Baltimore: Johns Hopkins University Press, 2008.

Smith, Susan L. Sick and Tired of Being Sick and Tired: Black Women's Health Activism in America, 1890-1950. Philadelphia: University of Pennsylvania Press, 1995.

Shaffer, Marguerite S. See America First: Tourism and National Identity, 1880-1940. Washington, D.C.: Smithsonian, 2001.

Scobey, David. Empire City: The Making and Meaning of the New York City Landscape. Philadelphia: Temple University Press, 2002.

Schwalm, Leslie A. Emancipation's Diaspora: Race and Reconstruction in the Upper Midwest. Chapel Hill: University of North Carolina Press, 2009.

Silber, Nina. The Romance of Reunion: Northerners and the South, 1865-1900. Chapel 
Hill: University of North Carolina Press, 1997.

Smith, Mark M. How Race Is Made: Slavery, Segregation, and the Senses, (Chapel Hill: University of North Carolina Press, 2006.

Sterngrass, John. First Resorts: Pursuing Pleasure at Saratoga Springs, Newport, and Coney Island, (Baltimore and London: Johns Hopkins University Press, 2001

Stevenson, Louise. Victorian Homefront: American Thought and Culture: 1860-1880. Ithaca and London: Cornell University Press, 1991.

Simon, Bryant T. Boardwalk of Dreams: Atlantic City and the Fate of Urban America. New York: Oxford University Press, 2004.

Spear, Alan. Black Chicago: The Making of a Negro Ghetto, 1880-1920. Chicago: University of Chicago Press, 1967.

Stanley, Amy Dru. From Bondage to Contract: Wage Labor, Marriage, and the Market in the Age of Slave Emancipation. New York: Cambridge University Press, 1998.

Sandoval-Strausz, A.K. Hotel: An American History. New Haven: Yale University Press, 2008.

----- "Travelers, Strangers, and Jim Crow: Law, Public Accommodations, and Civil Rights in America." Law and History Review, 23.1. (Spring, 2005).

Shannon Sullivan and Nancy Tuana. Race and Epistemologies of Ignorance, eds. New York: State University of New York Press, 2007.

Sze, Julie. Noxious New York: The Racial Politics of Urban Health and Environmental Justice. Cambridge, MA: MIT Press, 2007.

Trachtenberg, Alan. The Incorporation of America: Culture and Society in the Gilded Age. New York: Hill and Wang, 1982.

Walker, Juliet E.K. The History of Black Business in America: Capitalism, Race, Entrepreneurship. New York: Twayne, 1988.

Lewis Walker and Benjamin C. Wilson. Black Eden: The Idlewild Community. East Lansing: Michigan State University Press, 2002.

Walton, John. Histories of Tourism: Representation, Identity, and Conflict. New York: Multilingual Matters, 2005.

Weare, Walter B. Black Business in the New South: A Social History of the North Carolina Mutual Life Insurance Company. Urbana: University of Illinois Press, 
1973.

Weems, Jr., Robert. Desegregating the Dollar: African American Consumerism in the Twentieth Century. New York: New York University Press, 1998.

Weiss, Sheila Faith. Race Hygiene and National Efficiency: The Eugencis of Wilhelm Schallmayer. Berkeley: University of California Press, 1987.

Weiss, Thomas. "Tourism in American Before WWII." Journal of Economic History 64, 2 (June 2004).

Welke, Barbara. Law and the Borders of Belonging in the Long Nineteenth Century United States. Cambridge: Cambridge University Press, 2010.

----- "When All The Women Were White, and All the Blacks Were Men: Gender, Class, Race, and the Road to Plessy, 1855-1914." Law and History Review, 13, 2. (1995).

Weyeneth, Robert R. "The Architecture of Racial Segregation: The Challenges of Preserving the Problematic Past." Public Historian, 27.4. (2005).

Wiese, Andrew. Places of Their Own: African American Suburbanization in the Twentieth Century (Chicago: University of Chicago Press, 2004).

Wilcott, Victoria. Remaking Respectability: African American Women in Interwar Detroit (Chapel Hill: University of North Carolina Press, 2001).

Wilson, Harold F. The Jersey Shore: A Social and Economic History of the Counties of Atlantic, Cape May, Monmouth, and Ocean. New York: Lewis Historical Publishing Co., Inc, 1953.

----- The Story of the Jersey Shore. Princeton, NJ: D. Van Nostrand Co., Inc., 1964.

Wilson, Kirt H. The Reconstruction Desegregation Debate: The Politics of Equality and the Rhetoric of Place, 1870-1875. East Lansing: Michigan State University Press, 2002.

Wiltse, Jeff. Contested Waters: A Social History of Swimming Pools in America. Chapel Hill: University of North Carolina Press, 2007.

Woodward, C. Vann. The Strange Career of Jim Crow. New York: Oxford University Press, 1955.

Wolff, Daniel. $4^{\text {th }}$ of July, Asbury Park: A History of the Promised Land. New York: Bloomsbury Publishing, 2005. 